ROBERTA FIUSA MAGNELLI

\begin{abstract}
AVALIAÇÃO DOS EFEITOS GENOTÓXICOS E CITOGENÉTICOS DA PROTEÍNA L1 DO PAPILOMAVIRUS BOVINO ASSOCIADA ÀS SAPONINAS OBTIDAS DO RESÍDUO DE Agave sisalana Perrine (SISAL)
\end{abstract}

\begin{abstract}
Dissertação apresentada ao Programa de Pós-graduação Interunidades em Biotecnologia USP/Instituto Butantan/IPT, para obtenção do Título de Mestre em Biotecnologia.
\end{abstract}

São Paulo 2019 


\section{AVALIAÇÃO DOS EFEITOS GENOTÓXICOS E CITOGENÉTICOS DA PROTEÍNA L1 DO PAPILOMAVIRUS ASSOCIADA A SAPONINAS OBTIDAS DO RESÍDUO DE Agave sisalana Perrine (SISAL)}

Dissertação apresentada ao Programa de Pósgraduação Interunidades em Biotecnologia USP/Instituto Butantan/IPT, para obtenção do Título de Mestre em Biotecnologia.

Área de concentração: Biotecnologia

Orientadora: Dra. Rita de Cassia Stocco

Versão corrigida. A versão original eletrônica encontra-se disponível tanto na Biblioteca do ICB quanto na Biblioteca Digital de Teses e Dissertações da USP (BDTD). 


\section{CATALOGAÇÃO NA PUBLICAÇÃO (CIP) \\ Serviço de Biblioteca e informação Biomédica \\ do Instituto de Ciências Biomédicas da Universidade de São Paulo}

Ficha Catalográfica elaborada pelo(a) autor(a)

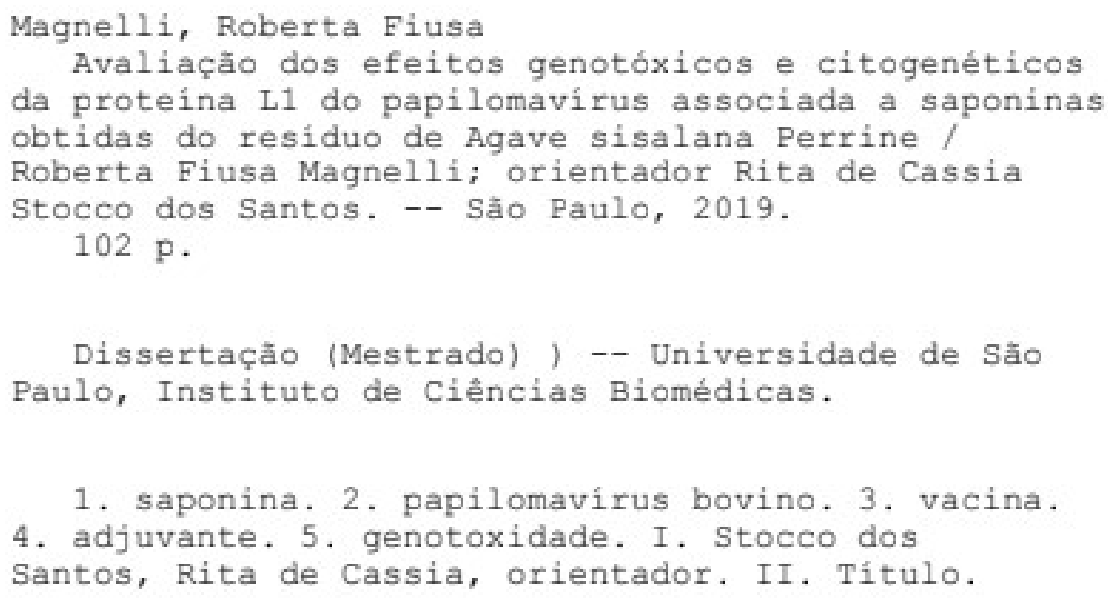

1. saponina. 2. papilomavirus bovino. 3. vacina. 4. adjuvante. 5. genotoxidade. I. Stocco dos Santos, Rita de Cassia, orientador. II. Título. 


\section{UNIVERSIDADE DE SÃO PAULO \\ Programa de Pós-Graduação Interunidades em Biotecnologia \\ Universidade de São Paulo, Instituto Butantan, Instituto de Pesquisas \\ Tecnológicas}

Candidato(a): Roberta Fiusa Magnelli

Título da Dissertação: Avaliação dos efeitos genotóxicos e citogenéticos da proteína L1 do papilomavírus associada a saponinas obtidas do resíduo de Agave sisalana Perrine (SISAL)

Orientador: Dra. Rita de Cassia Stocco dos Santos

A Comissão Julgadora dos trabalhos de Defesa da Dissertação de Mestrado, em sessão pública realizada a ............................., considerou o(a) candidato(a):
( ) Aprovado(a)
( ) Reprovado(a)

Examinador(a):

Assinatura:

Nome:

Instituição:

Examinador(a):

Assinatura:

Nome:

Instituição:

Examinador(a):

Assinatura:

Nome:

Instituição:

Presidente:

Assinatura:

Nome:

Instituição: 


\section{CERTIFICADO}

Certificamos que a proposta intítulada "AVALIAÇÃO DOS EFEITOS GENOTÓXICOS E CITOGENÉTICOS DA PROTEÍNA L1 DO PAPILOMAVIRUS ASSOCIADA À SAPONINAS", protocolada sob o CEUA $n^{\circ}$ 8296170317 (ID 000914), sob a responsabilidade de Rita de Cássia Stoceo - que envolve a produção, manutenȩão e/ou utilização de animais pertencentes ao filo Chordata, subfilo Vertebrata (exceto o homem), para fins de pesquisa científica ou ensino = está de acordo com os preceitos da Leí 11.794 de 8 de outubro de 2008, com o Decreto 6.899 de 15 de julho de 2009, bem como com as normas editadas pelo Conselho Nacional de Controle da Experimentaçẩo Animal (CONCEA), e foi aprovada pela Comissão de Ética no Uso de Animais da Instituto Butantan (CEUAIB) na reunião de 03/07/2017.

We certify that the proposal "EVALUATION OF GENOTOXIC AND CYTOGENETIC EFFECTS OF PAPILLOMA VIRUS L1 PROTEIN ASSOCIATED TO SAPONINS", utilizing 5 Bovines (males and females), protocol number CEUA 8296170317 (ID 000914), under the responsibility of Rita de Cássia Stoceo - which involves the production, maintenance and/or use of animals belonging to the phylum Chordata, subphylum Vertebrata (exeept human beings), for seientific research purposes or teaching = is in accordance with Law 11.794 of October 8,2008 , Decree 6899 of July 15, 2009, as well as with the rules issued by the National Couneil for Control of Animal Experimentation (CONCEA), and was approved by the Ethic Committee on Animal Use of the Butantan Institute (CEUAIB) in the meeting of 07/03/2017.

Finalidade da Proposta: Pesquisa

Vigência da Proposta: de 12/2016 a 12/2018 Área: Genética

Origem: Não se aplica

Espécie: Bovinos sexo: Machos e Fêmeas

idade: 1 a 10 meses

N: 5

Linhagem; SIMENTAL

Peso: 50 a $500 \mathrm{~kg}$

Local do experimento: A coleta de sangue periférico será realizada na Fazenda Santa Luzia, localizada no município de Itapetininga (SP) e os experimentos, no Laboratório de Genética do Instítuto Butantan.

*Reemissão de certificado, para correçẫo da data de vigência,

São Paulo, 21 de novembro de 2018

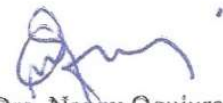

Dra. Nanfy Oguiura Vice-Coordenadora da CEUAIB 


\section{DEDICATÓRIA}

Ao meu pai (in memoriam), minha mãe e irmão,

pelo suporte e por me ensinarem desde cedo que o caminho do esclarecimento e o aprimoramento do espírito também passam pela dedicação aos

estudos. 


\section{AGRADECIMENTOS}

À minha orientadora Dra. Rita de Cássia Stocco pela confiança depositada, paciência e a valiosa oportunidade de cursar uma pós-graduação mesmo estando na condição de funcionária do Laboratório de Genética.

Ao Dr. Ronaldo Zucatelli Mendonça pela inestimável ajuda e apoio em todos os momentos, pelas idéias e disposição para que estas fossem postas em prática e pelo fornecimento das células Vero.

Ao Dr. Pedro Ismael Júnior pela generosidade em tempos críticos, disponibilidade em dividir seu conhecimento e laboratório, e por toda a ajuda nos experimentos e análises por HPLC e LC-MS.

À Dra. Adriana Neves pela amizade, confiança e por fazer ciência com humanidade e justiça.

Ao Dr. Durvanei Augusto Maria pela simpatia e boa vontade ao colaborar nas últimas etapas do meu trabalho com o fornecimento de Ciclofosfamida para que eu pudesse concluir meus experimentos.

À Myriam Palomino e Juliana Cuoco Badari, do laboratório de parasitologia do Instituto Butantan, pelo grande auxílio no tratamento dos dados, estatística e por compartilharem comigo suas habilidades no cultivo de células.

À Fundação Butantan e Instituto Butantan por viabilizarem as viagens de coleta de material e todo o suporte e estrutura científicos.

Aos alunos e funcionários do Laboratório de Genética (Rodrigo Franco Carvalho, Diego Grando Modolo, Jacqueline Mazzuchelli de Souza, Suely Assaf, Ivone, Dilce, Olga e Rose) que tanto contribuíram para que esse trabalho fosse possível.

Aos amigos da faculdade de filosofia por dividirem momentos de risadas, angústias e cubas libres, tornando o inexorável menos solitário.

Aos amigos do Instituto Adolfo Lutz, meu primeiro emprego e minha referência não só de profissionalismo, mas também de amizade.

À Associação dos Pós Graduandos da USP (APG-USP) e companheiros de ideologia pelas lutas que travamos juntos para que a Ciência brasileira e a Universidade não se perdessem nas mazelas do retrocesso.

À Secretaria do Programa de Pós-Graduação Interunidades em Biotecnologia por toda a atenção e colaboração durante minha pós-graduação. 
À Fundação de Amparo à Pesquisa do Estado de São Paulo (FAPESP) pelo apoio financeiro na parte experimental e à Coordenação de Aperfeiçoamento de Pessoal de Nível Superior (CAPES) pelo oferecimento de verba PROAP para divulgação deste trabalho. 
"Que nada nos limite, que nada nos defina, que nada nos sujeite. Que a liberdade seja a nossa própria substância." 


\section{RESUMO}

O papilomavírus bovino (BPV) é o agente etiológico da papilomatose bovina, caracterizada pela presença de papilomas que regridem espontaneamente, mas que podem persistir ou progredir à malignidade. $O$ vírus também é considerado o melhor modelo na compreensão do processo oncogênico do HPV. A classificação filogenética dos PVs é realizada com base na homologia de sequências da Open Reading Frame (ORF) L1, a mais conservada entre os diferentes sorotipos virais. Como a melhor forma de prevenção ainda é a intensificação dos controles gerais de manejo, há a necessidade do desenvolvimento de novas tecnologias vacinais. Tendo em vista a importância da proteína L1 e a imunogenicidade das saponinas, o presente trabalho tem por objetivo avaliar o potencial mutagênico e genotóxico da proteína isolada e purificada, bem como seus efeitos quando associada as saponinas, além de uma comparação com o adjuvante já bastante utilizado hidróxido de alumínio. Lesões genômicas, que após processadas sem reparação podem resultar em mutações, foram detectadas por meio de ensaio cometa. Possíveis danos ao material genético causados por alterações cromossômicas estruturais (clastogênese), bem como perdas cromossômicas (aneugênese) foram avaliadas pelo teste de micronúcleo. Ambos os testes foram feitos em eritrócitos policromáticos e células Vero. A avaliação de apoptose e necrose das células Vero tratadas foi feita por coloração com Anexina V/PI e citometria de fluxo. Os dois produtos vacinais (L1+Saponina e L1+Hidróxido de Alumínio) apresentaram danos compatíveis com o controle positivo no ensaio cometa e ambos elevaram levemente os níveis de micronúcleo, no ensaio de Viabilidade Celular os resultados com Hidróxido de Alumínio foram mais viáveis, caracterizando-o como um adjuvante mais seguro de acordo com os testes propostos. Algumas frações do extrato de saponina separadas por Cromatografia Líquida de Alta Eficiência foram avaliadas frente à atividade genotóxica por ensaio cometa, e suas identidades foram confirmadas por similaridade ao padrão de referência por espectrometria de massas.

Palavras-chave: papilomavírus bovino, vacina, adjuvante, saponina, genotoxicidade 


\begin{abstract}
Bovine papillomavirus (BPV) is the etiological agent of bovine papillomatosis, infectious disease characterized by the presence of benign tumors that can progress to malignancy.The phylogenetic classification of the PVs is performed based on the sequence homology of the Open Reading Frame L1, the most conserved among different viral serotypes. Given the importance of $L 1$ protein and the immunogenicity of saponins, these emerge as a promising candidate as adjuvant for veterinary use. Objectives: This study aimed to evaluate the mutagenic and genotoxic potential of the isolated and purified protein as well its effects when associated with saponins and a comparison with the adjuvant widely used aluminum hydroxide. Methods: Genomic lesions, which after processed without repair can result in mutations, were detected by comet assay. Possible damages to genetic material caused by structural chromosomal changes (clastogenesis), as well as chromosomal losses (aneugenesis) were evaluated by the micronucleus test. Both tests were done on polychromatic erythrocytes and Vero cells. The evaluation of apoptosis and necrosis of treated Vero cells was made by Annexin V / PI staining and flow cytometry. Results and Discussion: The two vaccine products ( L1 +Saponin and L1 + Aluminum Hydroxide) showed damages compatible with the positive control in the comet assay and both slightly elevated the micronucleus levels, in the Cell Viability Assay the results with Aluminum Hydroxide were satisfactory, characterizing Aluminum Hydroxide as a safer adjuvant according to the proposed tests, better than the saponins. Some fractions of the saponin extract separated by High Performance Liquid Chromatography were evaluated against genotoxic activity by comet assay, and their identities were confirmed by similarity to the reference standard by mass spectrometry.
\end{abstract}

Keywords: bovine papillomavirus, vaccine, adjuvante, saponin, genotoxicity 


\section{LISTA DE FIGURAS}

Figura 1 - Lesões características em bovinos acarretadas por papilomatose bovina com potencial

oncogênico

Figura 2 - Internalização do vírus na célula

hospedeira

Figura 3 - Endocitose e liberação dos lisossomos com genoma viral.

Figura 4 - Classificação dos tipos de BPVs descritos na literatura.

Figura 5 - Representação esquemática do genoma do papilomavírus bovino tipo 1(BPV1)

Figura 6 - Estrutura química geral das

Saponinas.

Figura 7 - Classificação das saponinas de acordo com a

Sapogenina.

Figura 8 - Produção de Sisal: sistema

sustentável.

Figura 9 - Classificação dos nucleóides de cometas de 0 a

2 .

Figura 10 - Formação de micronúcleos durante a fase da anáfase da mitose.

Figura 11 - Células saudáveis e apoptóticas com marcador de apoptose Anexina-

PI.

Figura 12 - Esquema geral de

metodologia

Figura 13 - Imagens de géis de eletroforese mostrando: a integridade do DNA genômico extraído.

Figura 14 - Gráfico estatístico de Ensaio cometa em células sanguíneas comparando os valores de escore das amostras tratadas em relação ao controle positivo. 
Figura 15 - Análise microscópica do Teste de Micronúcleo em células

Sanguíneas.

Figura 16 - Gráfico estatístico de Ensaio cometa em cultivo celular comparando os valores de escore das amostras tratadas em relação ao controle positivo.

Figura 17 - Histograma comparativo das porcentagens de micronúcleos contabilizados entre as amostras com os 8 tratamentos diferentes em células Vero 68

Figura 18 - Gráfico estatístico comparando as médias com desvio padrão de células viáveis das amostras tratadas em relação ao controle negativo. .70

Figura 19 - Gráfico em dot plot dos dados analisados em citometria de fluxo com anexina

PI. .71

Figura 20 - Gráfico estatístico dos dados analisados das células vero tratadas de acordo com a tabela 3.

Figura 21 - A: Perfil cromatográfico do Padrão Saponinas Sigma, B: Perfil cromatográfico da amostra de extrato

Saponina. .74

Figura 22 - Deconvolução dos espectros das frações do padrão nº5 e $\mathrm{n}^{\circ} 09$. .79

Figura 23 - Deconvolução dos espectros das frações da amostra n06 e no10.

Figura 24- Ilustração de duas principais sapogeninas que diferem em suas massas molares. 


\section{LISTA DE TABELAS}

Tabela 1 - Sequências dos iniciadores (primers) para diagnóstico

Tabela 2 - Parâmetros da reação de PCR empregando os diferentes pares de iniciadores.

Tabela 3 - Drogas testadas e concentrações de

trabalho.

Tabela 4 - Dados das amostras de sangue coletadas de recém - nascidos sem manifestações

clínicas.

Tabela 5 - Determinação por espectrofotômetro da concentração do DNA das amostras saguíneas

coletadas.

Tabela 6 - Resultados e escores obtidos na análise do potencial mutagênico por ensaio

cometa $60-61$

Tabela 7 - Valores estatísticos do teste post-hoc de Dunn do teste cometa em células

sanguíneas

Tabela 8 - Número de nucleoídes observados por classe e o respectivo valor do escore. 64-65

Tabela 9 - Valores estatísticos do teste post-hoc do teste cometa em cultivo celular.

Tabela 10 - Quantidade de micronúcleos encontrados por lâmina e frequência calculada.

Tabela 11 - Número de nucleoídes observados por classe e o respectivo valor do escore que demonstra o índice de dano nas frações obtidas por HPLC.

Tabela 12 - Comparativo entre padrão e amostra em relação a tempo de retenção e escore do ensaio cometa. 
$A$ - ampère

ACF - adjuvante completo de Freund

$\mathrm{ACN}$ - acetonitrila

AEHAS- extrato hidrolisado de Agave sisalana

AIF - adjuvante incompleto de Freund

BPV - papilomavírus bovino

Cdk - ciclina dependente de quinase

CLAE - cromatografia líquida de alta eficiência

cm - centímetro

Da - Dalton

DMSO - dimetilsulfóxido

DNA - deoxyribonucleic acid (ácido desoxirribonucleico)

E - proteínas de expressão precoce

EC - ensaio cometa

ECR - early control region

HPV - papilomavírus humano

IL - interleucina

INF - interferon

kDa - kilo Dalton

L - proteínas de expressão tardia

LC-MS - liquid chromatography- mass spectrometry

LCR - long control region

LMA - low melting point agarose (agarose de baixo ponto de fusão)

MHC - complexo principal de histocompatibilidade

min - minuto

$\mathrm{mL}$ - mililitro

$\mathrm{mM}$ - milimolar

MN - micronúcleo

ng - nanograma

NMA - normal melting agarose (agarose de ponto normal de fusão)

ORF - open reading frame (região de leitura aberta) 
Ori - origem de replicação

$\mathrm{pb}$ - pares de base

PCR - polymerase chain reaction (reação em cadeia de polimerase)

PHA - fitohemaglutinina $A$

PI - iodeto de propídeo

$\mathrm{pRb}$ - proteína retinoblastoma

PS - fosfatidilserina de membrana

SBA - adjuvante a base de saponinas

TFA - ácido trifluoracético

Th1 - linfócitos T helper (auxiliadores)

TMN - teste de micronúcleo

TMNBC - teste de micronúcleo com bloqueio de citocinese

$\mathrm{V}$ - volts

VLP - vírus-like particles (partículas semelhantes a vírus)

W - watts 


\section{SUMÁRIO}

1. INTRODUÇÃO

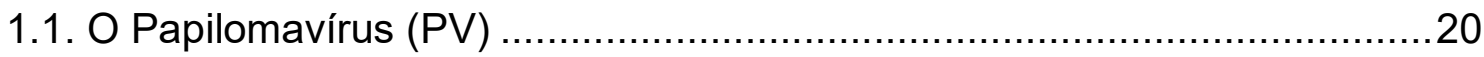

1.2. L1 como possível candidato vacinal contra o BPV .................................24

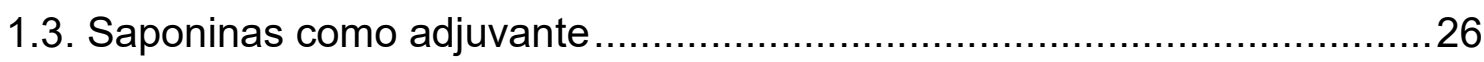

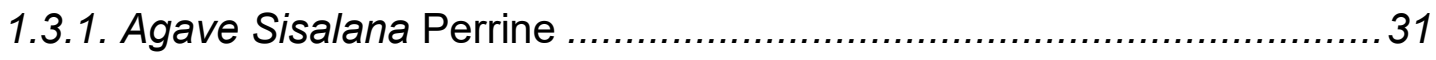

1.4. Ensaio Cometa como indicador de genotoxidade .....................................33

1.5. Teste do Micronúcleo com Bloqueio de Citocinese (TMBC) como indicador de mutagenicidade.

1.6. Citometria de fluxo: ensaio com Anexina V-PI como indicador de viabilidade celular e citotoxicidade

2. JUSTIFICATIVA

3. OBJETIVOS

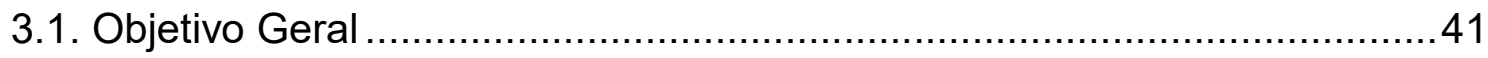

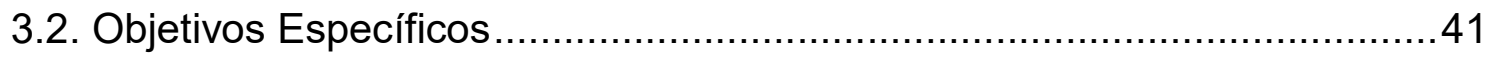

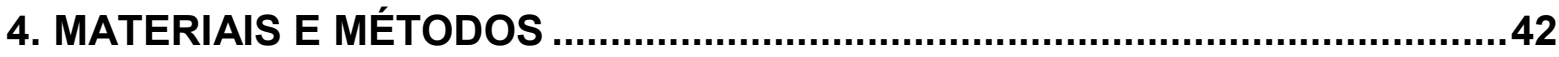

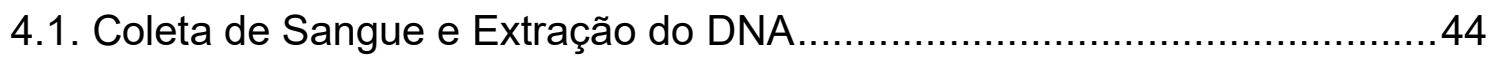

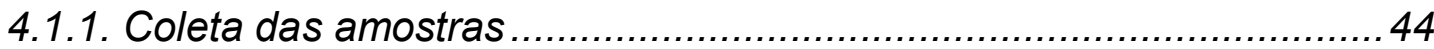

4.1.2. Extração do DNA genômico e viral .................................................. 44

4.2. Identificação e Tipagem Molecular de BPV ..............................................45

4.3. Obtenção do resíduo de sisal e preparação dos extratos ...........................46

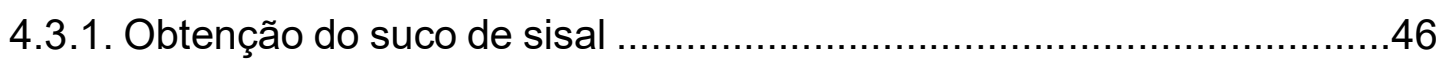

4.3.2. Obtenção do precipitado seco de sisal ...............................................46

4.3.3. Obtenção do extrato por hidrólise ácida ..........................................47

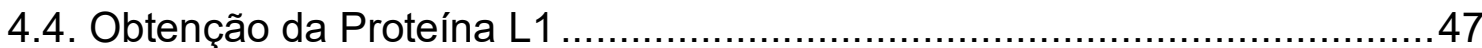

4.5. Teste do Micronúcleo com Bloqueio de Citocinese (TMBC) em Sangue

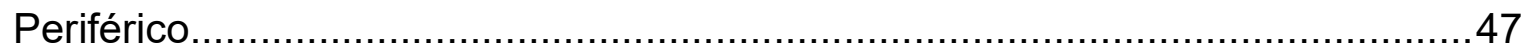

4.6 Teste do Micronúcleo com Bloqueio de Citocinese em Cultivo Celular ......49

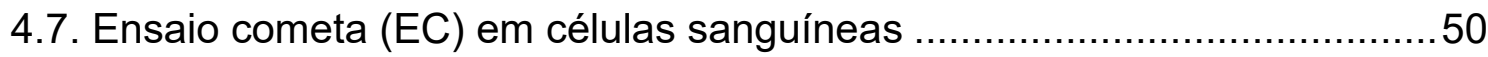

4.8. Ensaio cometa $(E C)$ em cultivo celular ................................................ 51

4.9. Citometria de fluxo: ensaio com Anexina-PI ......................................52 
4.10. Fracionamento cromatográfico por Cromatografia Líquida de Alta Eficiência (CLAE) do extrato bruto de Agave sisalana

Perrine

4.11. Ensaio cometa $(E C)$ em cultivo celular das frações obtidas por Cromatografia Líquida de Alta Eficiência (CLAE) das frações isoladas do extrato bruto de Agave sisalana Perrine .54

4.12. Quantificação por espectrofotometria de massas das frações selecionadas com atividade genotóxica

5. RESULTADOS 56

5.1.Coleta das amostras de sangue periférico 57

5.2. Extração e quantificação de DNA

5.3. Identificação e Tipagem Molecular de BPV nas amostras de sangue periférico .58

5.4. Ensaio cometa $(E C)$ em células sanguíneas 60

5.5. Teste do Micronúcleo com Bloqueio de Citocinese (TMBC) em Sangue Periférico. .63

5.6. Ensaio cometa (EC) em cultivo celular .64

5.7. Teste do Micronúcleo com Bloqueio de Citocinese em Cultivo Celular .....67

5.8. Citometria de fluxo: ensaio com Anexina-PI 69

5.9. Isolamento de substâncias por fracionamento cromatográfico .73

5.10. Ensaio cometa (EC) em cultivo celular das frações obtidas . .75

5.11. Análise e caracterização de substâncias por espectrometria de massa.

6.DISCUSSÃO .81

7.CONCLUSÃO .88 


\subsection{O Papilomavírus (PV)}

Os papilomavírus (PVs) são pequenos vírus de DNA dupla-fita circular, não envelopados e com simetria icosaédrica. (DOORBAR, 2005). Os PVs pertencem a família Papillomaviridae, sendo uma das mais antigas e extensas famílias de vírus conhecida (MUNDAY et al., 2014).

São considerados espécie-específicos (DE VILLIERS et al., 2004), entretanto, o papilomavírus bovino (BPV) é a única exceção (ZHOU et al., 2014). Isto porque os BPVs- 1,2 e 13 podem infectar diversas espécies, tais como: búfalos, antílopes, girafas, zebras (VAN DYK et al., 2011), mulas, felinos, coelhos, cavalos, répteis, anfíbios (CHAMBERS et al., 2003) e primatas não humanos, resultando em sarcomas, tumores invasivos, porém não metastáticos (LUNARDI et al.,2013) sendo o homem o hospedeiro mais extensivamente estudado dos PVs (DE VILLIERS et al., 2004).

Os PVs apresentam tropismo para células epiteliais e mucosas, causando lesões benignas (papilomas), que podem regredir espontaneamente ou progredir à malignidade (Figura 1) (STOCCO DOS SANTOS et al., 1998).

Neste contexto, o BPV destaca-se como o melhor modelo de estudos dos mecanismos oncogênicos dos PVs tendo em vista suas semelhanças genômicas e patológicas com o HPV (MUNDAY, 2014).

O BPV é o agente etiológico da papilomatose bovina, doença infectocontagiosa que afeta principalmente o gado jovem (STOCCO DOS SANTOS et al., 1998), apresenta uma distribuição mundial (HE et al., 2016; STOCCO DOS SANTOS et al., 1998), trazendo significativos prejuízos econômicos a todos os segmentos da cadeia produtiva da bovinocultura (NASCIMENTO et al., 2012). Estima-se que $60 \%$ do rebanho nacional esteja infectado pelo BPV (STOCCO DOS SANTOS et al., 1998), embora estes números possam ser ainda maiores, já que o vírus pode ser assintomático (ARALDI et al., 2013; SILVA et al., 2013). 
Figura 1 - Lesões características em bovinos acarretadas por papilomatose bovina com potencial oncogênico.

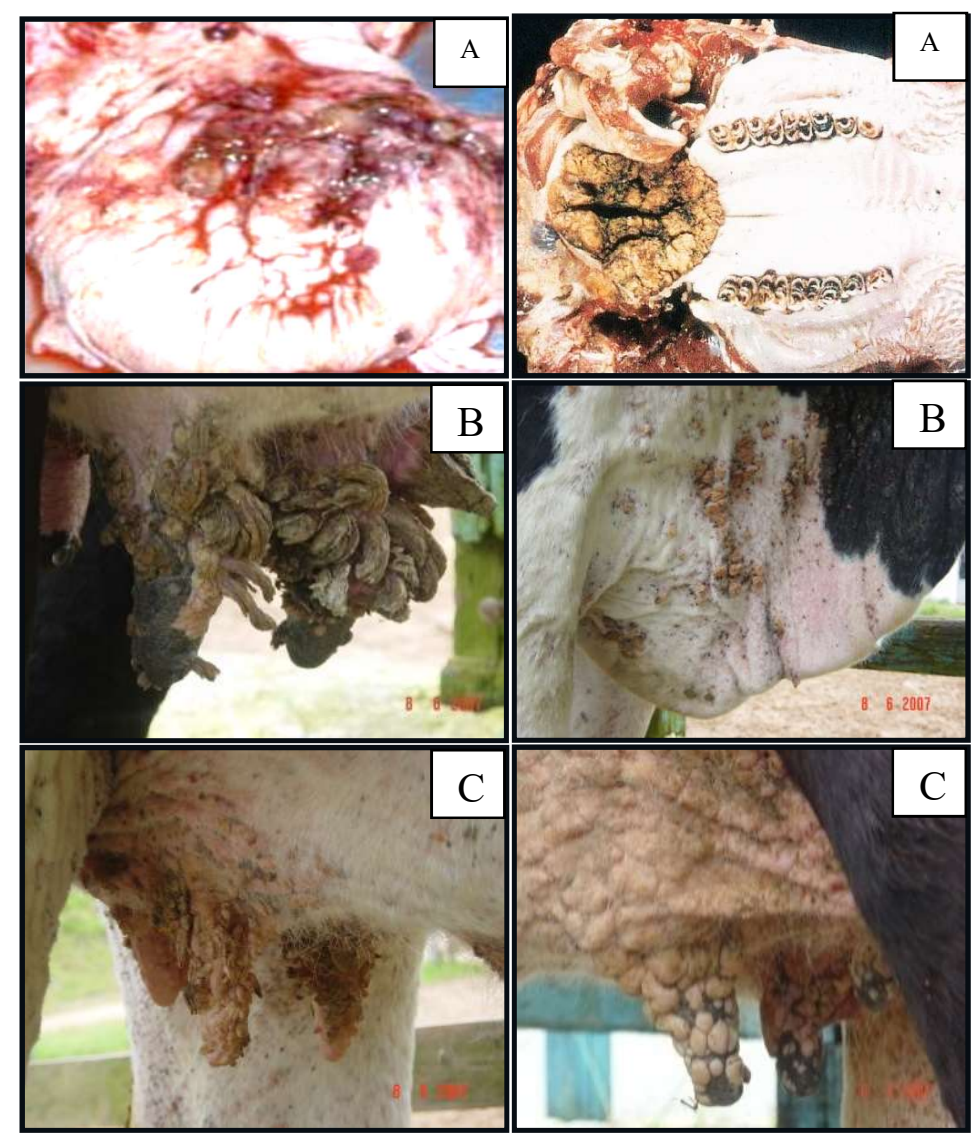
A) Tumor na bexiga: Borzacchiello e Roperto, 2008.
B) Progressão papiloma-carcinoma em gado: Campo, 2002.
C) Papiloma cutâneo em gado: Diniz et al, 2009.

São descritos na literatura 23 tipos de BPV (MUNDAY et al., 2015) classificados em quatro gêneros: Deltapapillomavirus (BPV- 1, 2, 13 e 14), Epsilonpapillomavirus (BPV-5 e 8), Dyoxipapillomavirus (BPV-7), Dyokappapilomavirus (BPV-16 e BPV-22), Xipapillomavirus (BPV- 3, 4, 6, 9, 10, 11, 12, 15, 17 e 20) (figura 4), o tipo 24 recentemente descoberto na Amazônia foi sugerido como um novo pertencente ao grupo Xipappilomavirus (GRINDATTO et al., 2015; DAUDT et al., 2018), e mais outros três (BPV- 18,19 e 21) permanecem sem classificação definida (SILVA et al., 2016; DAUDT et al. 2018b).

Além desses há mais de 32 supostos novos tipos sendo investigados (WHITE; HOWLEY, 2013), entretanto, o BPV-1 é o tipo viral mais bem estudado (BORZACCHIELLO \& ROPERTO, 2008). Isto porque foi o primeiro vírus a ser descoberto, bem como por estar associado a gênese de papilomas, fibropapilomas e carcinomas uroepiteliais (CAMPOS et al., 2013). Por este motivo, O BPV-1 é 
considerado um modelo para estudos de infecção e persistência do HPV (SCHILLER et al., 1984) e também um modelo nos estudos do BPV (BORZACCHIELLO \& ROPERTO, 2008).

A transmissão do vírus ocorre por meio do contato entre animais infectados ou em áreas contaminadas por partículas virais como: ordenhadeira mecânica, bebedouro, comedouro, cordas e cercas (MCBRIDE et al., 2012). Para que haja contaminação é necessária a lesão tecidual, a qual expõe os peptídeoglicanos de sulfato de heparina presentes na membrana da célula epitelial (LJUBOJEVIC; SKERLEV, 2014) que atuam como sítio de ancoragem da proteína L1, resultando na endocitose viral após uma série de alterações morfológicas dos vírions (FERNANDES et al., 2013).

As partículas virais do BPV são internalizadas (Figura 2) em estruturas vasculares que se associam a lisossomos, os quais induzem alterações de pK das proteínas do capsídeo viral (L1 e L2) por conterem conteúdo ácido, promovendo a liberação do genoma viral (figura 3), o qual permanece epissomal, diferente do HPV que pode se integrar ao DNA do indivíduo contaminado (DAY; LOWY; SCHILLER, 2003).

Figura 2 - Internalização do vírus na célula hospedeira.

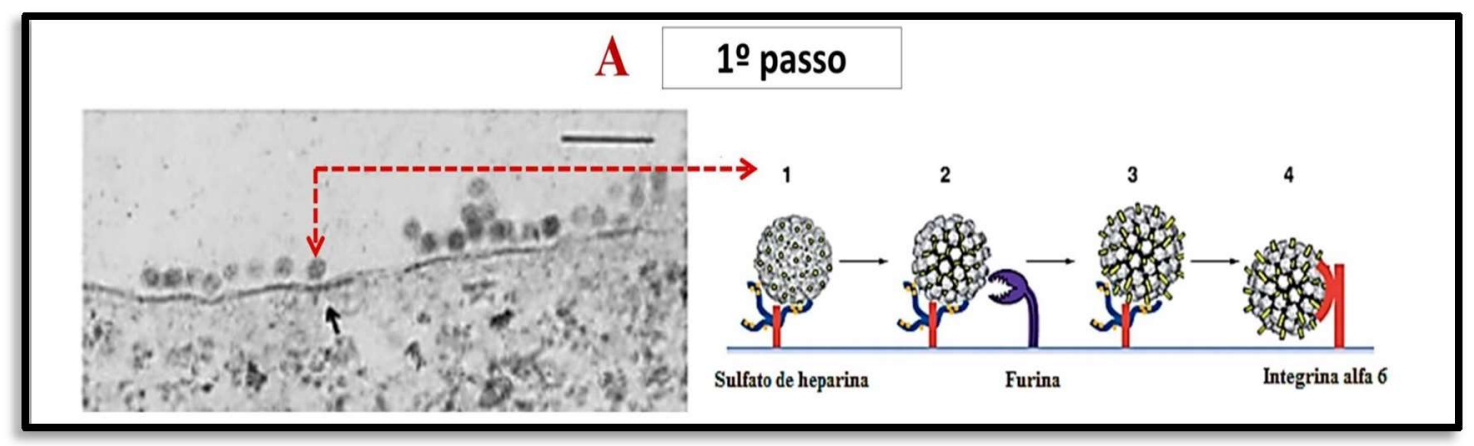

Figura 3 - Endocitose e liberação dos lisossomos com genoma viral.

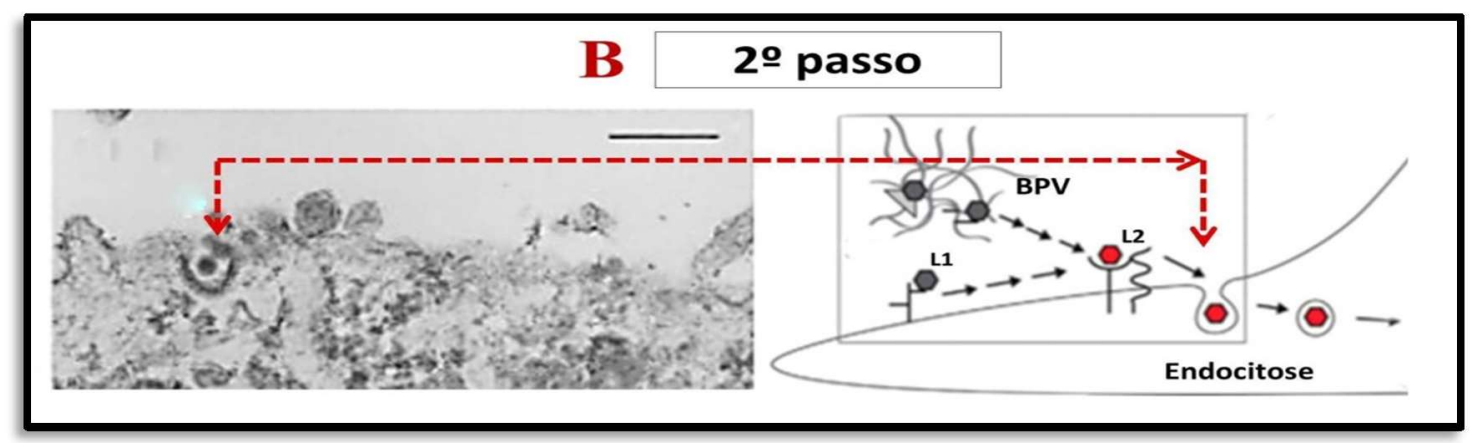

Modificadas a partir de Zhou et al., 1995. 
Figura 4 - Classificação dos tipos de BPVs descritos na literatura: Deltapapillomavirus, Epsilonpapillomavirus, Dyoxipapillomavirus, Dyokappapillomavirus e Xipapillomavirus.

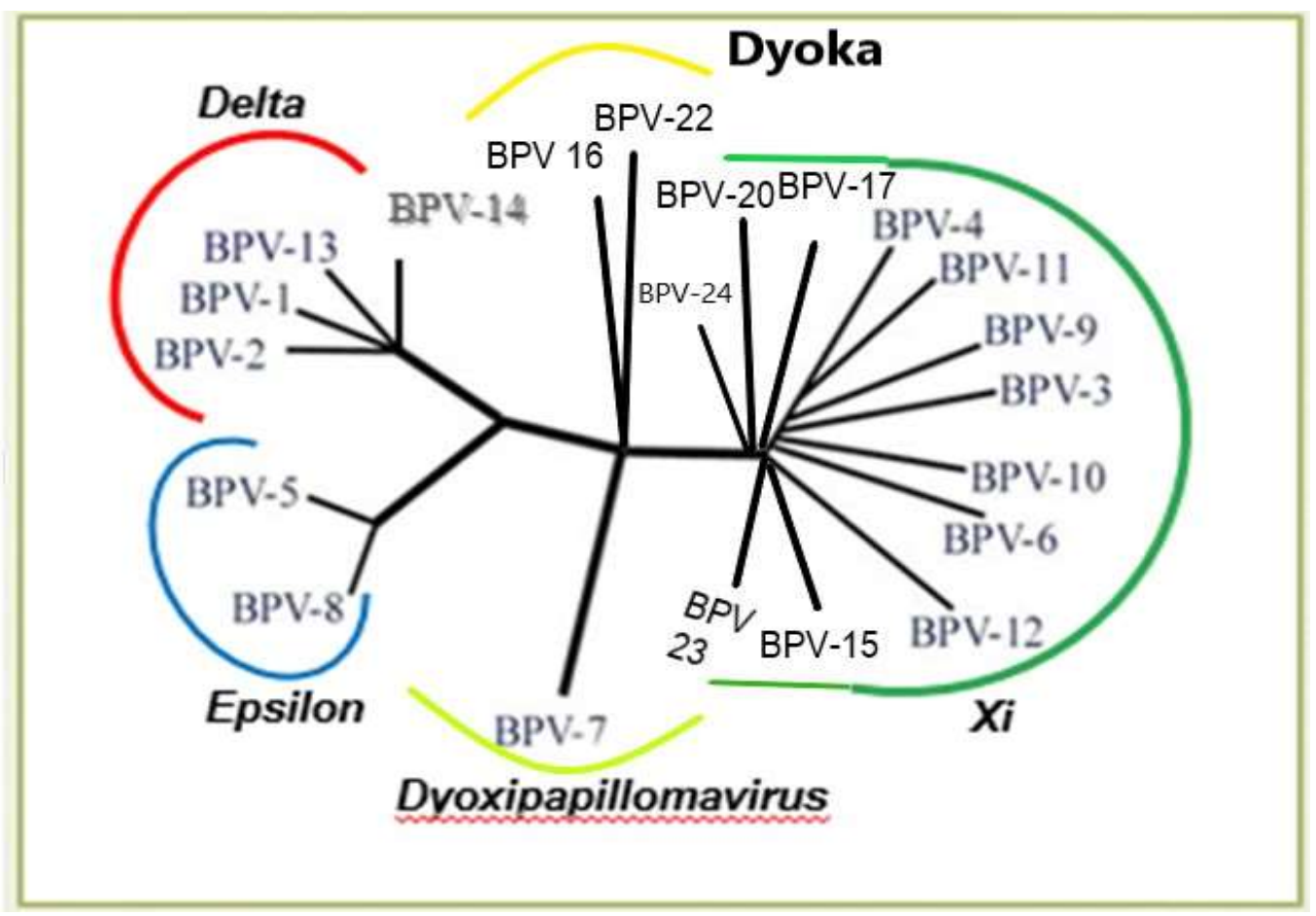

Modificada a partir de Gil da Costa et al., 2013.

O DNA viral encontra-se ligado a proteínas semelhantes a histonas. O capsídeo viral é composto por 72 capsômeros constituídos por duas proteínas estruturais de expressão tardia, L1 e L2. O genoma viral apresenta três regiões: a região E (early), L (late), e uma terceira região, a LCR (long control region) (ZHENG \& BAKER, 2006). Embora não codificante, a região LCR contém a origem de replicação (ori).

A região $L$ codifica as proteínas estruturais $L 1$ e $L 2$. A Open Reading Frame (ORF) L1 é a mais conservada entre os PVs (BUCK et al., 2013). Por este motivo, esta ORF é empregada na classificação filogenética desses vírus (DE VILLIERS et al., 2004). A ORF $L 1$ codifica a proteína $L 1$, que representa $80 \%$ das proteínas do capsídeo viral (MUNDAY et al., 2014). Esta proteína é altamente imunogênica, sendo, portanto, empregada em vacinas baseadas em virus-like-particles (VLPs) (BUCK et al., 2013). A proteína L2 auxilia no empacotamento do DNA viral pós-replicação (WANG \& RODEN, 2013). Ambas as proteínas L1 e L2 participam do processo de infecção viral (MUNDAY et al., 2014). 
A região $E$ possui sete ORFs (figura 5) (E1 a E7), responsáveis pela expressão de proteínas que participam ativamente no processo de replicação do BPV (CHEN \& LEE, 2015). Além do mais, está região contém as ORFs E5, E6 e E7, cujos produtos gênicos estão associados à indução e promoção da carcinogênese (CHEN et al., 2014). A oncoproteína E5 possui o maior potencial de transformação. Esta proteína promove, ainda, mudanças no pH das cisternas do complexo de Golgi (DIMAIO, 2014). Tal protonação resulta no sequestro de MHC-I, resultando na evasão do sistema imunológico (BORZACCHIELLO, 2007). A oncoproteína E6 promove a redução dos níveis de expressão da proteína supressora tumoral p53, levando a uma reposta anti-apoptótica e mutagênica (ARALDI et al, 2016). A oncoproteína E7 estimula a proliferação celular por meio da fosforilação da proteína pRb. Tal fosforilação resulta na liberação do fator de transcrição E2F, que se liga a promotores de cdks (DIMAIO, 2014).

Desta forma, as oncoproteínas induzem o estresse mitótico. Neste cenário, a redução dos níveis de expressão e o sequestro citoplasmático da p53 faz com que a célula perca a capacidade de reparar possíveis danos no DNA, aumentando a frequência das mutações como: rearranjos cromossômicos, clastogênese e aneuploidias (STOCCODOS SANTOS et al., 1998, ARALDI et al., 2013, 2015). O acúmulo de eventos mutacionais é a causa subjacente ao desenvolvimento de uma neoplásia, podendo resultar em câncer. (KEHMEIER et al., 2002; VOUSDEN, 1993).

\subsection{L1 como possível candidato vacinal contra o BPV}

Poucas intervenções médicas propostas no último século podem se igualar aos efeitos que a imunização exerceu sobre a longevidade (SCHUCHAT \& JACKSON, 2013). Por este motivo, a vacinação é considerada a medida de maior sucesso na prevenção, controle e erradicação de doenças de etiologia viral (RIBEIRO-MULLER, 2014). A imunização abranda consideravelmente os aspectos clínicos da doença, reduzindo, consecutivamente, complicações decorrentes da mesma (SCHUCHAT \& JACKSON, 2013). Além do mais, a imunização reduz a transmissão e disseminação do agente infeccioso (SCHUCHAT \& JACKSON, 2013).

Vacinas profiláticas contra o HPV estão disponíveis no mercado desde 2006 (RIBEIRO-MULLER, 2014). Tais vacinas são baseadas em VLPs (virus like particles) da proteína estrutural L1, já que está pode se auto organizar em pentâmeros 
(MARIGLIANI et al., 2012). Entre as vacinas disponíveis contra o HPV estão a Cervarix, produzida pela Merck e a Gardasil, pela Glaxo-Smith Klein (GSK) (RIBEIROMULLER, 2014). A Cervarix é uma vacina bivalente, conferindo proteção contra o HPV-16 e 18, empregando VLPs de L1 produzidos em leveduras e sulfato de hidrofosfato de alumínio como adjuvante (RIBEIRO-MULLER, 2014). A Gardasil é uma vacina quadrivalente, conferindo proteção contra o HPV-6, 11 (associados a verrugas genitais), 16 e 18 (alto risco), empregando VLPs de L1 produzidos em células de insetos e 3-O-deacilato-44-monofosforil lipídeo A (ASO4) como adjuvante (RIBEIRO-MULLER, 2014).

A proteína L1 é capaz de se auto organizar em pentâmeros, que compõe o capsídeo viral (RIBEIRO MULLER \& MULLER, 2014). A proteína L1 possui um papel chave nos mecanismos de infecção viral, garantindo a ancoragem do capsídeo aos receptores de sulfato de heparina (BUCK; DAY; TRUS, 2013). Tal ancoragem é essencial para garantir a infecção celular (FLORIN; SAPP; SPODEN, 2012). Deste modo, a imunodetecção desta proteína é considerada a principal evidência da infecção produtiva (COSTA; MEDEIROS, 2014; NASIR; REID, 1999).

Figura 5 - Representação esquemática do genoma do papilomavírus bovino tipo 1 (BPV1).

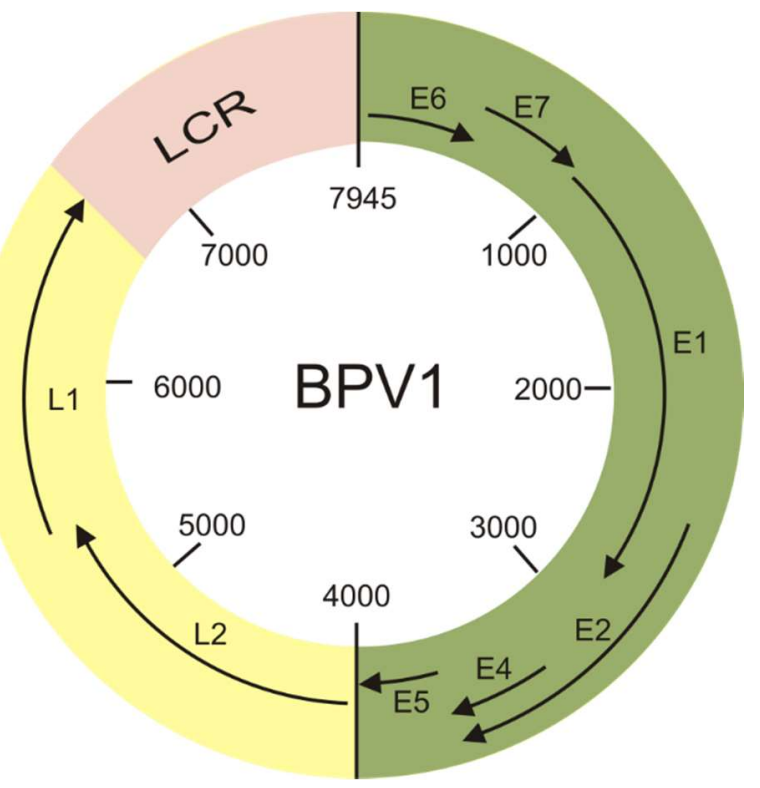

Fonte: https://www.intechopen.com/books/current-issues-in-molecular-virology-viralgenetics-and-biotechnolo0gical-applications/bovine-papillomaviruses-taxonomy-and-geneticfeatures, acesso em 20/08/2017. 
Embora duas vacinas profiláticas contra o HPV estejam disponíveis no mercado, até o momento não há vacinas comerciais contra o BPV. A ideia de desenvolver uma vacina contra os papilomas teve início com a injeção de extrato de papilomas na década de 1940 (SHOPE, 1937). Desde então, diferentes modelos vacinais foram propostos na literatura (CAMPO, 2006). Entretanto, nenhuma está disponível no mercado. Estudos mostram que as proteínas precoces do BPV (E6 e E7) apresentam ação terapêutica, ao passo que as estruturais (L1 e L2), profilática (CAMPO et al., 1997). Trabalhos baseados nas proteínas estruturais apontam que a proteína L2 apresenta uma imunogenicidade inferior a da L1, não sendo um bom candidato à vacina (RIBEIRO-MULLER, 2014). Além do mais, peptídeos isolados da porção amino-terminal de L2 de BPV-4 não foram capazes de induzir proteção contra a infecção pelo vírus (CAMPO et al., 1997). Neste sentido, as saponinas apresentamse como potentes candidatos a adjuvantes em vacinas baseadas em VLPs (PENG et al., 2015).

\subsection{Saponinas como adjuvante}

O adjuvante deve ser capaz de promover uma elevada e prolongada resposta imune e de induzir uma resposta biologicamente ativa por meio da modulação do sistema imunológico (AUDIBERT, 2003), além de direcionar essa resposta imune para uma resposta protetora, prevenindo a doença (MOREIN et al., 1996).

Compostos bioativos naturais derivados de plantas e do ambiente marinho são bem conhecidos pelas suas propriedades farmacológicas e efeitos terapêuticos na prevenção e tratamento de várias doenças. Contudo, antes de desenvolver agentes farmacêuticos a partir de fontes naturais é importante pesquisá-los quanto a sua citotoxicidade e atividade hemolítica em eritrócitos saudáveis (KUMAR et al., 2011, SHARMA et al., 2001). As saponinas, importante classe de produtos naturais possui amplo espectro de fatores biológicos e atividades farmacológicas (CHWALEK et al., 2006, GAUTHIER et al., 2009). Estas produzem espuma quando misturadas com água. As propriedades anfifílicas das saponinas permitem que elas interajam com as membranas das células (SOLTANI et al., 2014, AMINI et al., 2014). Embora o mecanismo subjacente à hemólise, promovida pelas saponinas, tenha permanecido indescritível, sabe-se que as saponinas interagem com colesterol nas membranas de eritrócitos, formando poros que as desestabilizam (CHWALEK et al., 2006, 
GAUTHIER et al., 2009). Esta atividade leva à liberação de hemoglobina e outros componentes nos fluidos circundantes.

No entanto, algumas saponinas exibem pouco ou nenhum efeito hemolítico (XIE et al., 2008), portanto, a relação estrutura-atividade é utilizada para explicar os efeitos químicos das saponinas sobre a atividade hemolítica e para identificar compostos ativos que não apresentem toxicidade para eritrócitos normais. Além disso, embora a atividade hemolítica dependa tanto das agliconas quanto do número e sequência das cadeias laterais de açúcares (CHWALEK et al., 2006, 2004) poucos estudos têm sido centrados na estrutura das sapogeninas e nas posições de grupos funcionais, os quais podem desempenhar papéis nas atividades biológicas de produtos naturais (CARELLI et al., 2011).

A estrutura das saponinas (figura 6 ) consiste em uma porção oligossacarídea formada por carboidratos como glicose, galactose, $\mathrm{N}$-acetilglucosamina, ácido glicurônico, xilose, ramnose ou metilpentose ligados a uma porção aglicona (nãoaçúcar), insolúvel em água, chamada genericamente de sapogenina e quando esta possui um esqueleto esteroidal, ela é chamada de sapogenina esteroidal. Portanto, sapogenina é a porção não-polar de uma saponina. (WILLIAMS \& GONG, 2007).

Figura 6 - Estrutura química geral das Saponinas

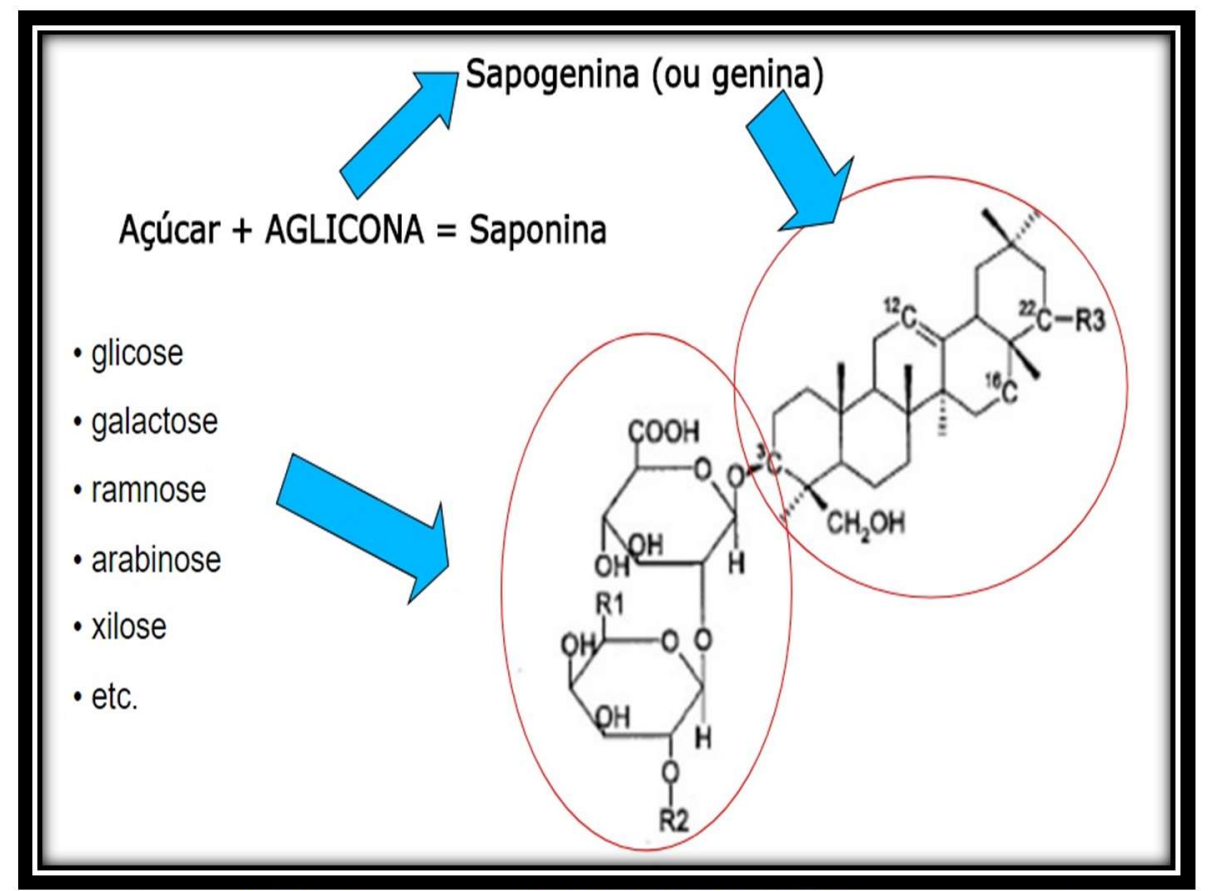

Fonte: https://slideplayer.com.br/slide/11214175/, acesso em 21/01/2019. 
As saponinas são glicosídeos triterpénicos ou esteroides (figura 7), abundantes em plantas e extratos marinhos (SOTHEESWARAN, 1988).

Esses glicosídeos possuem alta massa molecular (600 a 2000) e se apresentam em misturas complexas devido à presença concomitante de estruturas com um número variado de açúcares ou ainda devido à presença de diversas agliconas. A cadeia de açúcares pode ser linear ou ramificada e uma das dificuldades na elucidação estrutural desses compostos está justamente em determinar os carbonos das ligações interglicosídicas (SARKER \& NAHAR, 2009). Por essas razões, os isolamentos de saponinas, bem como esclarecimentos sobre sua estrutura, podem ser muito difíceis. É por isso, também, que o conhecimento sobre a química e propriedades biológicas de saponinas desenvolveu-se apenas mais recentemente, paralelo à evolução das técnicas cromatográficas e espectroscópicas (SIMÕES et al., 1999).

Figura 7 - Classificação das saponinas de acordo com a Sapogenina.

\section{saponinas esteroidais}

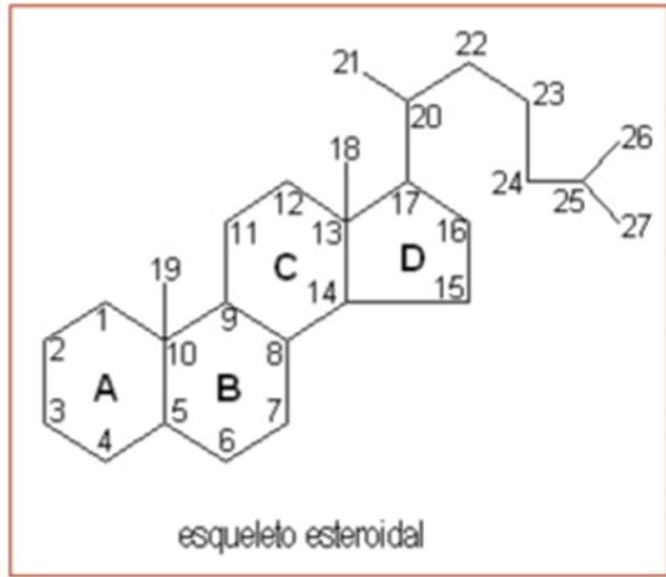

saponinas triterpênicas

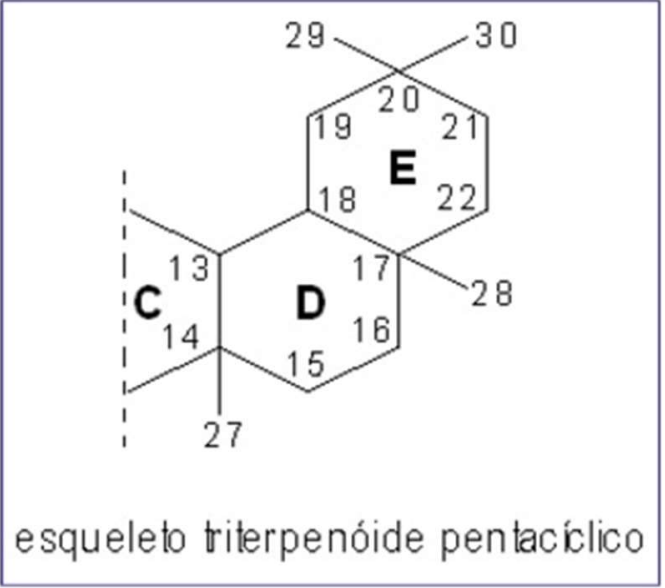

Fonte: https://slideplayer.com.br/slide/11214175/, acesso em 21/01/2019.

Tais glicosídeos, têm sido extensivamente estudados, revelando um forte potencial adjuvante que parece estar associado à sua capacidade de induzir produção de citocinas (SINGH \& O'HAGAN, 2003).

Muitos trabalhos foram realizados expondo a alta capacidade imunogênica e a baixa capacidade hemolítica, porém nenhum mostra a relação estrutura-atividade para essa classe geral de compostos, o que se deve a ausência de sistematização de 
informações disponíveis (ORTEGA et al., 2009). A relação entre atividade adjuvante e hemolítica já foi relatada, mas esses estudos basearam-se em poucas amostras (KENSIL et al., 1991; BOMFORD et al., 1992).

No entanto, os produtos naturais não são intrinsecamente seguros e eficazes, podendo gerar danos à saúde (NOHYNEK et al., 2010), o que justifica a necessidade de avaliação da segurança de novas matérias-primas vegetais, garantindo, dessa forma, boa condição de uso (ANTIGNAC et al., 2011).

Para vacinas humanas, os adjuvantes registrados são limitados e incluem adjuvantes aluminatados e a base de óleo / água. Estes adjuvantes induzem respostas de anticorpos robustas, mas uma imunidade mediada por células fraca. Os adjuvantes à base de saponina (SBAs) aumentam a resposta Th1, através da estimulação de citocinas (IL-2 e INF-y) (SINGH E O'HAGAN, 2003, KENSIL, 1995).

Estudos em raiz de Polygala senega L. (Polygalaceae), uma planta indígena das pradarias canadenses, indicaram grande potencial das saponinas como adjuvante em vacinas, aumentando a resposta imune específica em ratos estimulados imunizados com rotavírus (ESTRADA et al., 2000).

Vacinas a base de proteínas sem um adjuvante induzem respostas imunológicas muito fracas, as saponinas são adjuvantes potentes, (SLOVIN et al., 2005) quando purificadas, apresentam elevada capacidade adjuvante e já são usadas em vacinas veterinárias (GUPTA et al., 1993).

No entanto, foi com a descoberta do adjuvante completo de Freund (ACF), em 1937, que o uso das emulsões em procedimentos de imunização tornou-se frequente. O ACF é um dos mais potentes adjuvantes descritos para diversos antígenos e usados extensivamente em procedimentos experimentais com animais de laboratório, porém, em sua formulação original, mostrou-se inaceitável para uso em humanos devido a complicações inflamatórias (GUPTA et al., 1993). As vacinas com adjuvantes a base de óleo são utilizadas com sucesso em programas de controle de doenças na América do Sul (PATIL et al., 2002) e outras partes do mundo.

As emulsões lipídicas são conhecidas como os efetivos adjuvantes capazes de induzir uma resposta imune elevada e duradoura (HILLEMAN, 1966; EDELMAN, 1980; GUPTA \& SIBER, 1995). Um dos maiores problemas encontrados para vacinas com adjuvantes oleosos é que o uso frequente pode resultar em reações adversas indesejáveis, tais como formação de granulomas e cistos, que são atribuídas a diversos fatores incluindo impurezas do óleo (BARTELING \& VREESWIJK, 1991; 
GUPTA et al., 1993) e no caso do ACF e AIF (adjuvante incompleto de Freund), muitos dos efeitos adversos são creditados ao óleo mineral, pelo fato de não ser biodegradável, formando lesões ulcerativas no local da injeção. Devido a esses efeitos colaterais, uma larga variedade de óleos e derivados vem sendo testada, como o esqualeno, esqualano e óleos vegetais (CHANG et al., 1998).

Durante as últimas nove décadas, algumas formulações de adjuvantes têm sido desenvolvidas, sendo que poucas foram testadas em triagens clínicas e grande parte apresenta elevada toxicidade e efeitos adversos (GUPTA \& SIBER, 1995). Estudos mostram que falhas nos processos de vacinação dos animais produzem efeitos adversos que contribuem de forma significativa para perdas em carcaças por meio de lesões vacinais (ASSUMPÇÃO \& PACHENSHY, 2011). Paranhos da Costa, et al. (2006), constataram que a baixa eficiência no processo de vacinação é a grande responsável pela formação de reações vacinais e perdas nas carcaças, o que leva à redução do lucro do pecuarista. O óleo mineral, presente em vacinas para febre aftosa e em medicamentos é um grande catalisador de formação de absessos sendo responsável pela depreciação e eliminação de grandes porções de carne e couro (MORO et al., 2011).

Sais minerais baseados em alumínio foram introduzidos na terapêutica há mais de 50 anos, por apresentarem bons níveis de segurança, porém são pouco eficazes na indução de anticorpos nas subunidades de proteínas e também na imunidade mediada por célula (SYRJANEN, 1999).

O Hidróxido de alumínio injetado com um antígeno forma um depósito de sais de alumínio nos tecidos do animal gerando um granuloma rico em macrófagos. $O$ antígeno dentro deste granuloma é liberado de forma lenta proporcionando um estímulo antigênico prolongado.

Estes adjuvantes a base de alumínio promovem boas respostas em forma de anticorpos, porém com pouco efeito sobre as respostas mediadas por células. Em experimentos com saponinas conseguiu-se uma melhor resposta celular quando se associam os dois compostos (RIVERA et al., 2003, HU et al., 2003). Estudos recentes de uma vacina para HPV16, associando E6/E7 a L2 com saponinas demonstraram sua alta eficácia e menor citotoxicidade durante o tratamento quando comparada ao potente quimioterápico, Cisplatina, comumente utilizado na terapêutica. O composto formulado com saponinas estendeu a sobrevida de camundongos infectados e 
retardou o crescimento do tumor após tratamento apenas com Cisplatina (RODEN, 2015).

\subsubsection{Agave Sisalana Perrine}

A Agave sisalana Perrine (Figura 8), conhecida popularmente como sisal, é uma herbácea originada no México e adaptada ao clima semiárido da Caatinga (GUTIERREZ et al., 2008). Esta espécie está distribuída no Nordeste do Brasil, onde seu cultivo ocupa extensas áreas de solos pobres, sendo considerada uma importante alternativa produtiva para essa região (RIBEIRO FILHO, 1967), ocupando um importante papel socioeconômico, especialmente aos agricultores familiares, desde o manejo da lavoura, a colheita, o desfibramento, o beneficiamento da fibra, a industrialização e/ou confecção de artesanatos (MARTIN, 2009).

Essa espécie é monocotiledônea e fonte de fibra dura em áreas semi-áridas da qual o Brasil é o maior produtor e exportador do mundo e a Bahia é responsável por $80 \%$ da produção da fibra nacional. Teve seu apogeu econômico durante a Crise do Petróleo nas décadas de 60 e 70 e apenas $4 \%$ dos cortes das folhas do sisal produzem fibra, o restante do material é comumente descartado por fazendas de sisal (BANDEIRA \& SILVA, 2006).

O sisal também é ecologicamente correto, enquanto a fibra sintética demora até 150 anos para se decompor no solo a fibra do sisal em poucos meses torna-se um fertilizante natural (NAVES, 2013; SANTOS, 2006), além de constituir fonte de renda e emprego para um grande contingente de trabalhadores e ser um importante agente de fixação do homem à região semiárida nordestina, haja visto, em algumas dessas regiões, ser a única alternativa de cultivo com resultados econômicos satisfatórios (ALVES et al., 2004).

Estima-se que o sisal ofereça aproximadamente 500 mil postos de trabalho de forma direta e indireta, por meio de sua cadeia de atividades, que começa com a manutenção das lavouras, a colheita, o desfibramento e o beneficiamento da fibra, e termina com a industrialização e a confecção de artesanato (SILVA et al., 2006). 
Figura 8 - Produção de Sisal: sistema sustentável
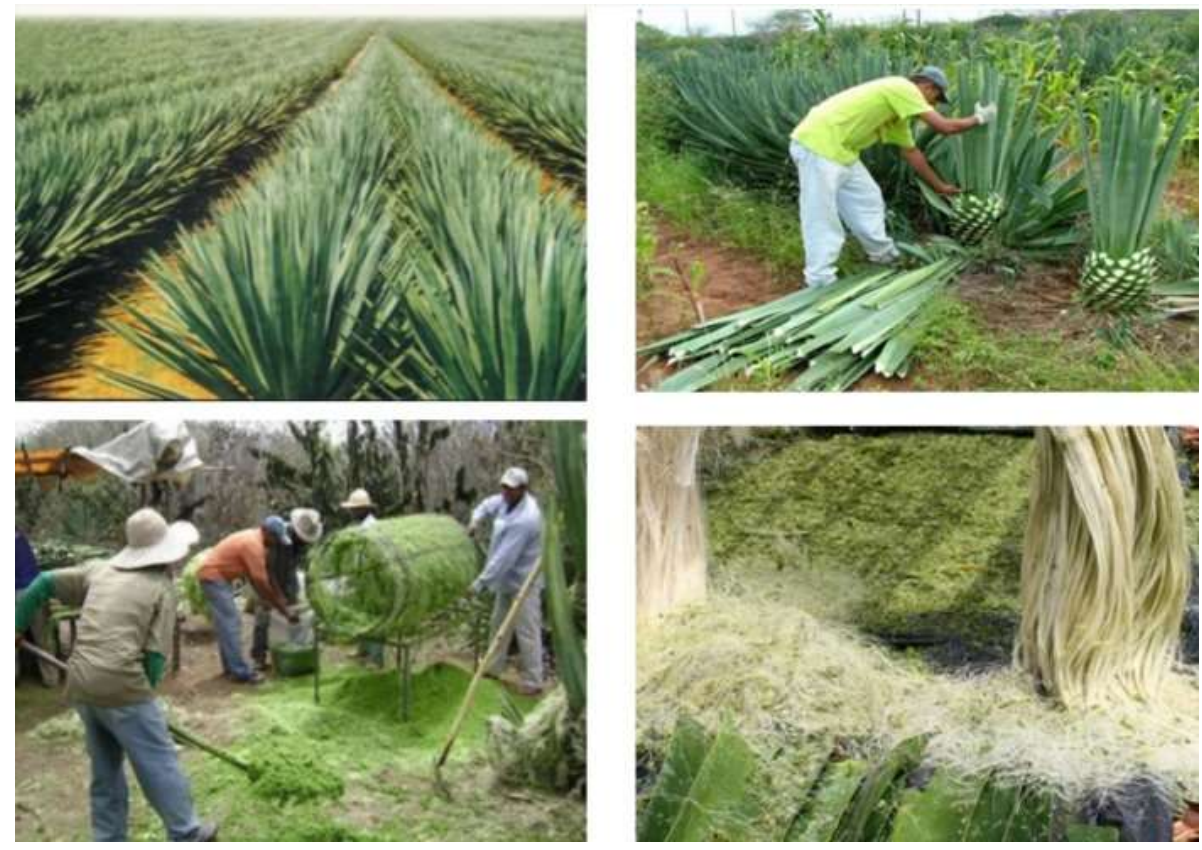

Fonte: http://slideplayer.com.br/slide/11663258/, acesso em 15/08/2017.

As monocotiledôneas são as principais fontes de saponinas esteroidais, como alguns representantes das famílias Liliaceae, Dioscoreaceae e Agavaceae e podem ser também encontradas nas famílias Amaryllidaceae, Bromeliaceae e Palmae. Estudos recentes identificaram saponinas espirostanas em dicotiledôneas, como nas famílias Asteraceae (Aspilia montevidensis), Balanitaceae (Balanites aegyptiaca), Leguminosae (Trigonella foenum-graecum) e Zygophyllaceae (Tribulus terrestres) (FRANCIS et al., 2002).

As saponinas espirostanas encontradas em Agave apresentam-se como uma importante classe de produtos naturais para as indústrias farmacêuticas por ser matéria-prima para a produção de hormônios sexuais (principalmente anticoncepcionais, corticosteróides, diuréticos esteroidais e vitamina $D)$ (HOSTETTMANN \& MARSTON, 1995).

As principais atividades biológicas de espécies de Agave que apresentam saponinas espirostanas em sua estrutura química são hipocolesterolmia e antiinflamatória (Agave americana) (KINTIA et al., 1996), moluscicida (Agave decipiens) (BRACKENBURY \& APPLETON, 1997), antiinflamatória (Agave intermixta) (ABDEL-GAWAD et al., 1999), antifúngica (Agave sisalana) (GARCIA et al., 2000).

Estudos de atividade adjuvante e hemotílica em Agave sisalana ainda são escassos, bem como a segurança no seu uso farmacêutico. Pesquisas ainda não 
publicadas realizadas na UNESP pelo laboratório de Biotecnologia demonstram que em concentrações acima de $50 \mu \mathrm{g} / \mathrm{mL}$ saponinas extraídas de Agave sisalana são altamente hemolíticas, porém abaixo disso não possuem efeito imunoadjuvante satisfatório, sendo esta a concentração ideal de escolha para maiores estudos de citotoxidade e genotoxidade (SOUZA, 2017,comunicação pessoal).

\subsection{Ensaio Cometa como indicador de genotoxidade}

Para que uma substância seja aceita para uso comercial é necessário que passe por testes de genotoxicidade, sendo esta uma especialidade recente, e se situa na interface entre a toxicologia e a genética, por isto frequentemente denominada de genética toxicológica (SILVA et al. 2006).

A genética toxicológia visa o estudo dos processos que alteram a base genética da vida, quer seja na sua estrutura físico- -química, o ácido desoxirribonucleico (DNA), processo classificado como mutagênese; quer seja na alteração do determinismo genético a níveis celulares e orgânicos, identificados, respectivamente, como carcinogênese e teratogênese (SILVA et al. 2003).

O ensaio cometa (EC) foi desenvolvido por Östling e Johanson em 1984 e modificado por Sinh et al. (1994), que atribuíram maior sensibilidade à técnica com a utilização de solução alcalina, sendo considerado eficaz nos testes citogenéticos (FLORES \& YAMAGUCHI, 2008).

A vantagem deste método é a simplicidade e versatilidade, onde podemos utilizar um número pequeno de células, podendo ser realizado com qualquer população celular eucariótica (KHOEl et al., 2011). Essa técnica pode ser utilizada em uma vasta gama de organismos (humanos, animais, plantas), tanto em culturas in vitro com in vivo (Neri et al., 2015).

Ao contrário de outros tipos de ensaios, que avaliam células em divisão, para averiguar sua viabilidade, o Teste Cometa não necessita dessa condição, podendo ser realizado com células estáveis, geralmente linfócitos, pois são obtidos facilmente por meio de coleta de sangue (GONTIJO \& TICE, 2003). Porém, outros tecidos, como o fígado e os rins, também já foram testados (MITCHELMORE \& CHIPMAN, 1998).

A técnica é amplamente aceita e utilizada em pesquisas de genética toxicológica e médica, ecogenotoxidade, para fins diagnósticos e de tratamentos 
médicos, biomonitoramento ambiental, estudos de células apoptóticas e sistemas de reparo de DNA (KASSIE et al.,2000)

O EC é empregado na detecção de danos no DNA, sendo o principal integrador e complementar a outros testes mutagênicos (TICE et al.,2000) tendo por finalidade identificar quebras induzidas por mutágenos na molécula de DNA (FABIANI et al.,2008).

As células na lâmina são submergidas em gel de agarose e então colocadas em campo elétrico, que atua promovendo a migração dos segmentos de DNA livres, resultante de quebras, adquirindo a aparência de um cometa (ARALDI et al., 2013).

A região nuclear origina a cabeça do cometa enquanto que os fragmentos, a cauda, cuja extensão está diretamente relacionada com a intensidade do dano (OLIVE \& BANATH, 2006), que é verificada por meio de microscopia óptica de fluorescência (Figura 9), onde as células são criteriosamente analisadas e classificadas em diferentes graus de lesão (HARTMANN et al. 2003).

O EC não é utilizado para detectar mutações, mas sim lesões no DNA que, após serem processadas, podem resultar em mutações. Diferentes das mutações, as lesões detectadas pelo teste são passíveis de correção, sendo assim, o teste necessita de controles muito bem estabelecidos por ser muito sensível, o tempo entre a exposição e a análise deve ser o mais curto possível, pois o dano pode ser reparado, por isto o tempo curto de detecção. Assim sendo, o teste cometa pode ser utilizado também para estudos de reparo do DNA (ALBERTINI et al. 2000).

Figura 9 - Classificação dos nucleóides de cometas de 0 a 2.

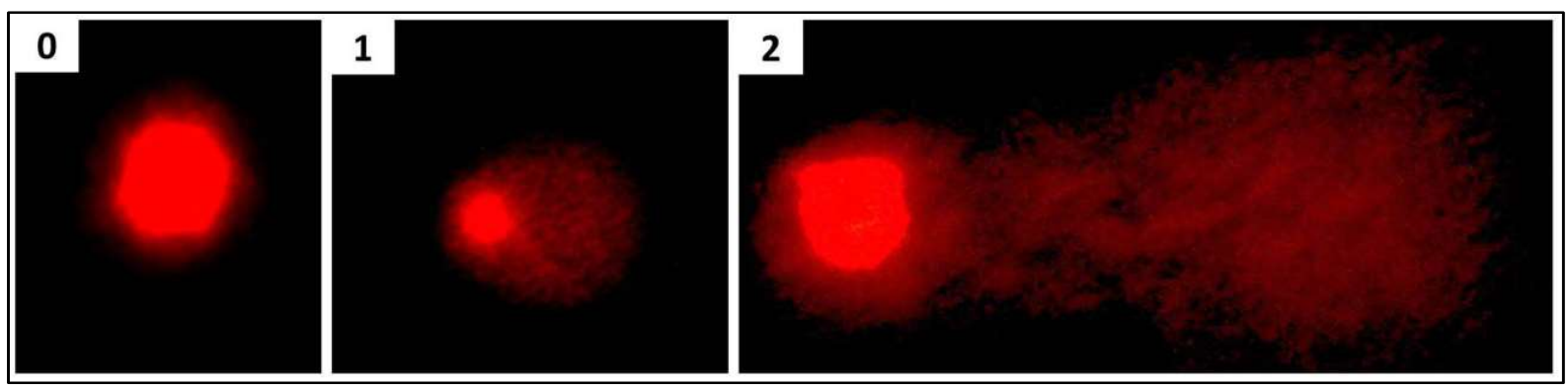

Nucleóide de classe 0 (sem dano), nucleóide de classe 1 (dano intermediário) e nucleóide de classe 2 (dano máximo). 


\subsection{Teste do Micronúcleo com Bloqueio de Citocinese (TMBC) como indicador de mutagenicidade}

O teste do micronúcleo é um teste de mutagenicidade que identifica danos cromossômicos por meio da presença de micronúcleos (MNs) (NORPPA \& FALCK, 2003).

O micronúcleo é um tipo de dano cromossômico ou anomalia mitótica que se originam a partir de fragmentos de cromossomos ou cromossomos inteiros. Durante a fase da anáfase da mitose eles não são capazes de interagir com o eixo formado na citocinese e, portanto, não são incorporados aos núcleos filhos (Figura 10) (KirschVOLDERS et al. 2011).

Figura 10 - Formação de micronúcleos durante a fase da anáfase da mitose.

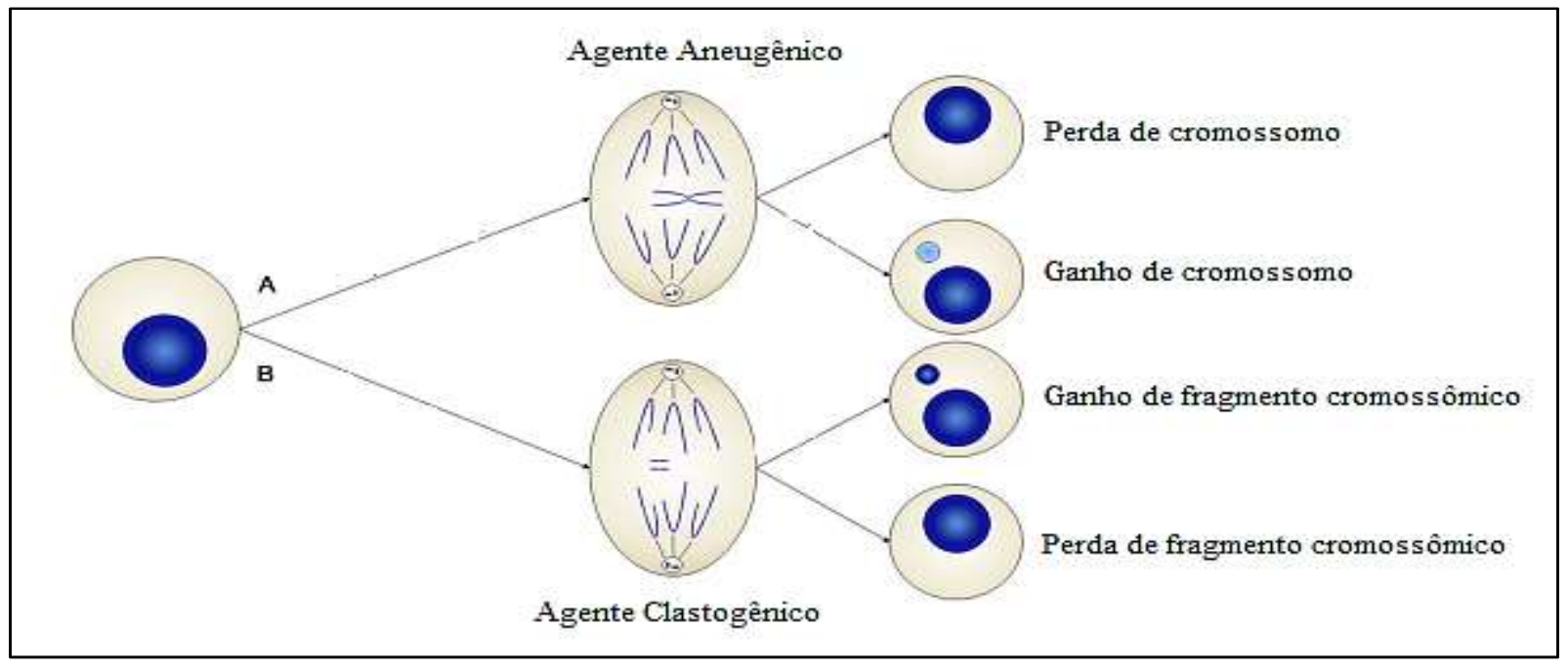

Modificado a partir de Terradas et al 2010.

Sua formação deve-se a alterações estruturais cromossômicas espontâneas ou decorrentes de fatores ambientais (RIEGER, 1968). Quando essas aberrações ocorrem em células somáticas, podem levar à formação de neoplasia (RAMIREZ \& SALDANHA, 2002).

Em 1985, a técnica foi adaptada usando citocalasina B para bloquear a citocinese, sem bloqueio da mitose, e diferenciar as células que passaram por um ciclo de divisão. Este método ficou conhecido como técnica de micronúcleos com 
bloqueio de citocinese (CBMN, de cytokinesis-block micronucleus). Os micronúcleos podem ser analisados em células tratadas com citocalasina B ou não, sem o bloqueio do processo de citocinese (VALENTE et al. 2017).

CBMN pode revelar, através de simples critérios morfológicos, genotoxicidade e citotoxicidade por quebra cromossômica (clastogênese), perda de cromossomo (aneugênese), rearranjo cromossômico (pontes citoplasmáticas), inibição da divisão celular, necrose e apoptose (FENECH \& MORLY, 1985; FENECH, 2000; GONTIJO \& TICE, 2003).

A frequência de micronúcleos nas células é considerada um parâmetro citogenético por ser um forte indicativo da associação entre as extensas mudanças cromossômicas e a transformação celular. O acúmulo dessas anormalidades aponta uma instabilidade cromossômica, o que pode levar a um mecanismo carcinogênico (THOMAS et al. 2003). Recentemente, evidências acumuladas sugerem indução de parada no ciclo celular ocasionando apoptose (TERRADAS et al., 2010).

Os procedimentos de marcação podem ser usados também quando há um aumento na formação de micronúcleos e o pesquisador pretende determinar se esse aumento é resultado de eventos clastogênicos ou aneugênicos. São dados que enriquecem enormemente a dosimetria biológica (WU \& RODE, 2002).

\subsection{Citometria de fluxo: ensaio com Anexina V-PI como indicador de viabilidade celular e citotoxicidade}

A apoptose é um processo natural de morte celular programado geneticamente que ocorre durante o desenvolvimento embrionário, bem como na manutenção da homeostase do tecido, sob condições patológicas e no envelhecimento. O processo é caracterizado por características morfológicas específicas, incluindo perda de plasma assimetria e fixação da membrana, condensação do citoplasma e do núcleo e clivagem internucleosomal do DNA (KERR et al., 1999). Nas células apoptóticas, a fosfatidilserina (PS), uma proteína de membrana, é translocada do folheto interno para o exterior da membrana plasmática, assim expondo a PS ao ambiente celular externo. Anexina $\mathrm{V}$ é um proteína de ligação de fosfolípidio dependente de $\mathrm{Ca} 2+$ com alta afinidade para PS e liga-se a superfície celular apoptótica expondo a PS (VERMES et al.,1995). A anexina $\mathrm{V}$ pode ser conjugada com fluoroforos, mantendo a sua alta 
afinidade por PS e que, portanto, serve como uma sonda para análise em citometria de fluxo de células submetidas à apoptose (CASCIOLA-ROSEN et al., 1996).

A translocação PS precede a perda da integridade da membrana, que acompanha as fases posteriores da morte celular resultantes de processos apoptóticos ou necróticos (Figura 11).

Figura 11 - Células saudáveis, recentemente apoptóticas e tardiamente apoptóticas/necróticas com marcador de apoptose Anexina-PI.
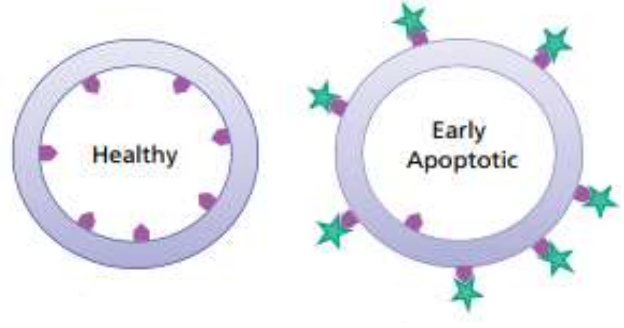

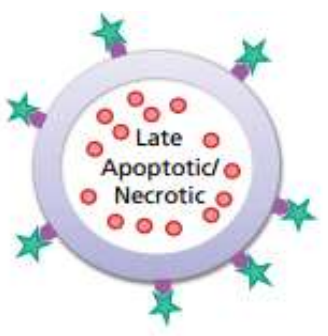

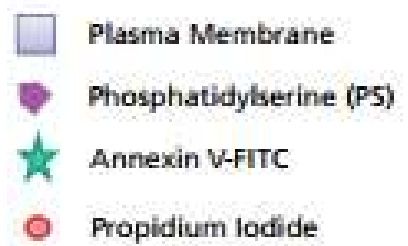

Propidium lodide

Modificado a partir de Hingorani et al.,2011.

Portanto, a coloração das células com Anexina $V$ é tipicamente usada em conjunto com um corante vital, tal como o iodeto de propídio (PI), para identificação de apoptose precoce e tardia nas células. As células viáveis com membranas intactas excluem PI, enquanto as membranas de células necróticas e danificadas são permeáveis ao PI. Portanto, células que são consideradas viáveis são anexina $\mathrm{V}$ e PI negativos, enquanto células que estão em apoptose precoce são Anexina $\vee$ positiva e PI negativa, e células que estão em apoptose tardia ou já estão em necrose tanto Anexina V quanto PI positivas (van ENGELAND et al.,1996). 
O Laboratório de Genética do Instituto Butantan tem se dedicado ao estudo do BPV por mais de duas décadas, contribuindo em diferentes segmentos da pesquisa, como descoberta de novos tipos virais no Estado de São Paulo (ARALDI et al., 2014b; MELO et al., 2014), novos métodos diagnósticos (CARVALHO et al., 2013), isolamento viral (ARALDI et al., 2014a), expressão de proteínas recombinantes (MAZZUCHELLI-DE-SOUZA et al., 2013), análise de alterações citogenéticas (CAMPOS et al., 2013; MELO et al., 2011; STOCCO DOS SANTOS et al., 1998) e estudos patológicos dos papilomas e carcinomas associados ao vírus (ARALDI et al., 2017).

A papilomatose bovina não representa apenas um problema de buiatria, mas também econômico (CAMPO, 2002; NASCIMENTO et al., 2012), pois a pecuária representa um dos principais segmentos do agronegócio brasileiro, abrangendo duas vertentes altamente lucrativas: as cadeias produtivas de carne e leite.

Além do mais, O BPV é considerado o melhor modelo de estudo do HPV (CAMPO, 2002). Há uma grande variedade de estudos sobre vacinas profiláticas e terapêuticas contra o Papilomavírus humano (HPV), o qual apresenta grande relevância na área da saúde humana por sua associação a vários tipos de malignidades, incluindo o câncer cervical e de cabeça e pescoço (CAMPANA et al., 2013).

Para HPV já há duas vacinas no mercado que conferem proteção aos tipos 16, 18, 11, 6, ou somente o 16 e 18 que são os principais causadores do câncer. Entretanto, não há vacinas disponíveis no mercado contra o BPV. As vacinas terapêuticas experimentais são baseadas na indução de imunidade celular, expressando antígenos virais, visando à regressão de lesões associadas (PAHEL et al., 1993).

Os procedimentos desenvolvidos têm sido o ponto de partida para estudos sobre estratégias vacinais, e a obtenção de proteínas recombinantes e saponinas em laboratório permite um estudo minucioso de sua ação conjunta. A clonagem em vetores bacterianos para a expressão e purificação de proteínas apresenta vantagens como a grande quantidade de biomassa gerada, baixo custo relativo e rapidez, servindo a diferentes propósitos, porém, para que se chegue a um produto final, muitas etapas deverão ser realizadas, sendo o presente estudo uma avaliação de proteína recombinante associada a um possível adjuvante, sendo esta, uma proposta de extrema importância. 


\subsection{Objetivo Geral}

O estudo tem por objetivo avaliar o potencial genotóxico, mutagênico e citotóxico da proteína L1 do BPV associada ao adjuvante saponina e fazer uma comparação com a ação da mesma proteína recombinante associada ao adjuvante hidróxido de alumínio.

\subsection{Objetivos Específicos}

- Avaliar a ação genotóxica e mutagênica nas amostras de células sanguíneas e células Vero após tratamento com os produtos vacinais por meio de ensaio cometa e ensaio de micronúcleo;

- Quantificar as células Vero apoptóticas e viáveis após tratamento com os produtos vacinais por citometria de fluxo;

- Fazer uma comparação entre os resultados obtidos com Saponinas e Hidróxido de Alumínio para as técnicas aplicadas utilizando testes estatísticos;

- Fracionar o extrato de saponinas utilizado por meio de método cromatográfico e verificar ação genotóxica das frações eluídas por ensaio cometa;

- Identificar e caracterizar as frações que apresentaram atividade genotóxica por espectrometria de massas. 
4 MATERIAIS E MÉTODOS 
A metodologia do trabalho seguiu o esquema demonstrado na figura 12, sendo dividido em duas partes:

Figura 12 - Esquema geral de metodologia

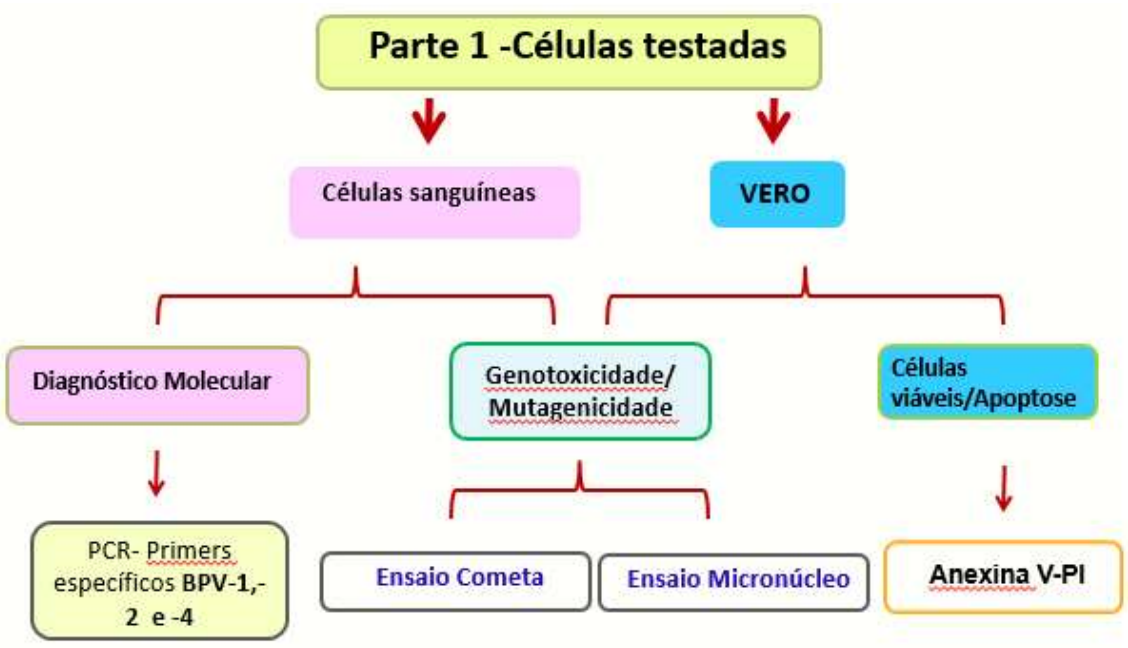

Parte 2 - Estudo cromatográfico de saponina

Fracionamento por HPLC

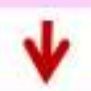

Comparação de tempo de retenção entre Padrão e amostra

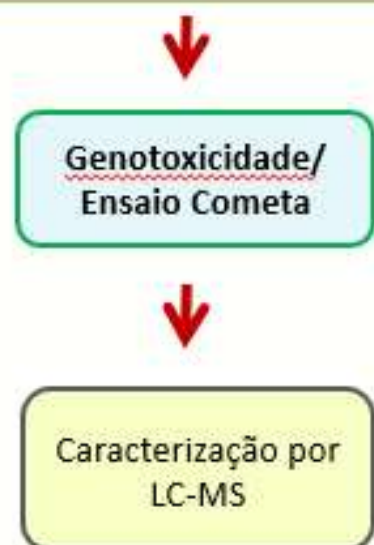




\subsection{Coleta do Sangue e Extração do DNA}

\subsubsection{Coleta das amostras}

Foram coletados $10 \mathrm{~mL}$ de sangue periférico de dez bovinos (Bos taurus, Simental) por meio de punção venosa da veia jugular, empregando tubos a vácuo contendo heparina potássica.

As amostras de sangue foram coletadas no município de Itapetininga e transportadas para o Laboratório de Genética do Instituto Butantan em caixas térmicas para evitar eventuais danos no material genético, bem como para preservar as células viáveis, permitindo assim a incubação do material biológico para a realização do Teste do Micronúcleo com Bloqueio de Citocinese realizado impreterivelmente no mesmo dia.

\subsubsection{Extração do DNA genômico e viral do sangue coletado}

O material destinado à extração de DNA foi conservado a $-20^{\circ} \mathrm{C}$. O DNA foi extraído empregando o kit QIAamp ${ }^{\circledR}$ DNA Blood Mini Kit (Qiagen, Hilden, Alemanha), de acordo com as instruções do fabricante. O DNA extraído foi quantificado em espectrofotômetro BioPhotometer Plus (Eppendorf, Hamburgo, Alemanha), onde foi realizada a leitura de uma alíquota de $2 \mu \mathrm{L}$ das respectivas amostras em comprimentos de onda de 230, 260 e 280 nm, calculando a concentração em ng/ $\mu \mathrm{L}$, por meio da multiplicação do valor da absorbância pelo coeficiente de extinção. 


\subsection{Identificação e Tipagem Molecular de BPV}

O sangue coletado foi submetido à identificação molecular de sequências de BPV empregando o conjunto de pares de iniciadores (primers) mostrados na tabela 1, por serem estes os principais causadores das manifestações clínicas do BPV.

Tabela 1 - Sequências dos iniciadores (primers) para diagnóstico.

\begin{tabular}{|c|c|c|c|}
\hline Primer & Sequência (5'-3') & Gene alvo & $\begin{array}{l}\text { Tamanho } \\
\text { esperado } \\
\text { de } \\
\text { amplicon } \\
\text { (pb) }\end{array}$ \\
\hline BPV-1 & $\begin{array}{c}\text { GGAGCGCCTGCTAACTATAGGA } \\
\text { ATCTGTTGTTTGGGTGGTGAC }\end{array}$ & $\mathrm{L} 1$ & 301 \\
\hline BPV-2 & $\begin{array}{l}\text { GTTATACCACCCAAAGAAGACCCT } \\
\text { CTGGTTGCAACAGCTCTCTTTCTC }\end{array}$ & L2 & 164 \\
\hline BPV-4 & $\begin{array}{l}\text { GCTGACCTTCCAGTCTTAAT } \\
\text { CAGTTTCAATCTCCTCTTCA }\end{array}$ & E7 & 170 \\
\hline
\end{tabular}

Parâmetros da PCR: Foram realizadas reações com um volume total de $25 \mu \mathrm{L}$, sendo estas compostas por $18 \mu \mathrm{L}$ de PCR Master Mix (Quatro G, Porto Alegre) (100 $\mathrm{mM}$ de Tris- $\mathrm{HCl}, \mathrm{pH}=8,5,500 \mathrm{mM} \mathrm{KCl}, 1,7 \mathrm{mM}$ de $\mathrm{MgCl}_{2}, 0,2 \mathrm{mM}$ de dNTPs e 1, 5 $\mathrm{U}$ de Taq DNA Polimerase recombinante) $1 \mu \mathrm{L}$ do primer forward, $1 \mu \mathrm{L}$ do primer reverse e $5 \mu \mathrm{l}$ da amostra de DNA extraído em cada tudo de polipropileno. As reações foram levadas ao termociclador Veriti 96 Well Thermal Cycler (Applied Biosystems, Singapura) e submetidas aos seguintes ciclos descritos na tabela 2.

Tabela 2 - Parâmetros da reação de PCR empregando os diferentes pares de iniciadores (primers).

\begin{tabular}{|c|c|c|}
\hline & \multicolumn{2}{|c|}{ Primers específicos } \\
\hline & Tempo & Temperatura \\
\hline Inicio & $3 \mathrm{~min}$ & $94^{\circ} \mathrm{C}$ \\
\hline Desnaturação & $50 \mathrm{~s}$ & $94^{\circ} \mathrm{C}$ \\
\hline Anelamento & $1 \mathrm{~min}$ & $60^{\circ} \mathrm{C}$ \\
\hline $\begin{array}{c}\text { Extensão } \\
\text { Ciclos }\end{array}$ & \multicolumn{2}{|c|}{35} \\
\hline Extensão final & $5 \mathrm{~min}$ & $72^{\circ} \mathrm{C}$ \\
\hline
\end{tabular}


Condições da eletroforese: Os produtos resultantes da PCR foram analisados em gel de agarose a 2\%, em tampão TAE (Tris-acetato EDTA), corado com 1, $0 \mu \mathrm{L}$ de GelRed (Biotium Inc., Hayward, CA, EUA) / $100 \mathrm{~mL}$ de solução de agarose. A corrida eletroforética foi realizada em cuba Horizon 20.25 (Life Technologies, Carlsbad, EUA), empregando a fonte PowerPacBasic (Bio-Rad, Singapura), a $100 \mathrm{~V}$, 400 mA, durante 120 minutos, aplicando o marcador 100 pb DNA Ladder (Invitrogen, Carlsbad, EUA). O gel foi visualizado em transluminador BioDocAnalyze (Biometra, Goettingen, Alemanha) e as imagens capturadas por meio do software BioDocAnalyze versão 2.1 (Biometra, Goettingen, Alemanha) 3.3.

\subsection{Obtenção do resíduo de sisal e preparação dos extratos}

\subsubsection{Obtenção do suco de sisal}

A matéria-prima foi obtida a partir da sua extração na Bahia (suco do Sisal) diretamente do processo de desfibramento das folhas de Agave sisalana em fazenda de cultivo de sisal localizada na cidade de Valente, Bahia (latitude $11^{\circ} 44^{\prime} 24^{\prime \prime} \mathrm{S}$, longitude $39^{\circ} 27143^{\prime \prime}$ W e altitude $585 \mathrm{~m}$ ) por meio de uma parceria com a Secretaria de Ciência, Tecnologia e Inovação do Estado da Bahia (SECTI) e Laboratório de Tecnologia Farmacêutica em Fitoterapia do campus da UNESP-Assis. Para isso, as folhas foram secas a $50^{\circ} \mathrm{C}$ utilizando-se secador elétrico e trituradas com auxílio de um triturador mecânico até obter a forma de pó.

\subsubsection{Obtenção do precipitado seco de sisal}

Para obter o precipitado seco de $A$. sisalana, o suco do sisal foi centrifugado (FANEM FR 22) a 4000 rpm por 20 minutos com uma força centrípeta de aproximadamente $52.580 \mathrm{~N}$. Posteriormente o sobrenadante foi seco em estufa (FANEM LTDA, modelo 002CB) a $40^{\circ} \mathrm{C}$, até obtenção do peso constante. 


\subsubsection{Obtenção do extrato por hidrólise ácida}

O extrato de hidrólise ácida de $A$. sisalana (AHEAS) foi preparado de acordo com Duender et al. 41 . Em detalhes: o suco de sisal foi aquecido a $100^{\circ} \mathrm{C}$ e resfriado por dez vezes, e hidrolisado com $\mathrm{HCL} 2 \mathrm{~N}$ durante quatro horas, sob agitação. $\mathrm{O}$ precipitado foi separado da solução ácida por filtração em membranas (Millex ${ }^{\circledR}$ ) à temperatura ambiente.

Os extratos foram liofilizados e mantidos a $4^{\circ} \mathrm{C}$ até o uso. Este processamento e a concentração de estudo foram obtidos pelo laboratório de Biotecnologia, da Universidade Julio Mesquita (UNESP- Assis) e encaminhados para o Instituto Butantan por colaboração para a realização do presente trabalho.

\subsection{Obtenção da Proteína L1}

A proteína L1 foi expressa e purificada no laboratório de Genética do Instituto Butantan, por Modolo (2014), e cedida para este trabalho para os testes de mutagenicidadee genotoxidade na concentração de $1 \mathrm{ug} / \mathrm{mL}$ de acordo com Modolo et al, 2017.

O gene L1 de BPV-1, previamente clonado em pAT153, foi inserido em um vetor de expressão $\mathrm{pET} 28 \mathrm{a}$. O vetor denominado $\mathrm{pET}$ L1 foi clonado em bactéria $E$. coli dH5 $\alpha$ e subsequentemente inserido em bactérias BL21 para a expressão proteica. E. coli BL21 modificadas (DE) foram utilizadas para a expressão da proteína. A expressão da proteína recombinante foi avaliada por Western Blot e espectrometria de massa. A purificação de proteínas foi realizada por cromatografia de afinidade e troca iônica, passando então por análise espectroscópica por dicroísmo circular para avaliar sua dobradura e estabilidade térmica.

\subsection{Teste do Micronúcleo com Bloqueio de Citocinese (TMBC) em Sangue Periférico}

O sangue coletado foi incubado em tubos Falcon de $15 \mathrm{~mL}$ contendo: $4,5 \mathrm{~mL}$ de meio RPMI 1640, suplementado com $0,5 \mathrm{~mL}$ de soro fetal bovino e $0,1 \mathrm{~mL}$ de fitohemaglutinina A (PHA). A cada tubo foram acrescentados $200 \mu \mathrm{L}$ de sangue total. A incubação de sangue total é preferencialmente recomendada, pois o isolamento de 
células mononucleares de sangue periférico com Ficoll-Paque pode induzir danos no DNA (Araldi et al., 2015). Os tubos foram incubados em estufa a $37^{\circ} \mathrm{C}$.

Após $8 \mathrm{~h}$ de incubação as 10 amostras foram tratadas conforme tabela 3 :

Tabela 3 - Drogas testadas e concentrações de trabalho.

\begin{tabular}{c|c|c}
\hline Abreviações & Droga testadas & Concentrações \\
\hline C- (Controle negativo) & $\begin{array}{c}\text { Células sem nada } \\
\text { aplicado }\end{array}$ & - \\
\hline $\mathrm{C}+($ Controle positivo) & $\begin{array}{c}\text { Ciclofosfamida } \\
\text { (diluída em PBS) }\end{array}$ & $50 \mathrm{ug} / \mathrm{mL}$ \\
\hline $\mathrm{L} 1$ & $\begin{array}{c}\text { L1 de BPV-1 } \\
\text { (diluída em PBS) }\end{array}$ & $1 \mathrm{ug} / \mathrm{mL}$ \\
\hline $\mathrm{H}$ & $\begin{array}{c}\text { Hidróxido de } \\
\text { Alumínio }\end{array}$ & $10 \mathrm{uL} / \mathrm{mL}$ \\
\hline L1+H & $\begin{array}{c}\text { L1 de BPV-1 } \\
\text { Recombinante (diluída em } \\
\text { PBS)+ Hidróxido de } \\
\text { Alumínio }\end{array}$ & $10 \mathrm{uL} / \mathrm{mL}$ \\
\hline S & $\begin{array}{c}\text { Extrato aquoso de } \\
\text { Agave sisalana (diluída } \\
\text { em PBS e DMSO 2\%) }\end{array}$ & $50 \mathrm{ug} / \mathrm{mL}$ \\
\hline L1+S & $\begin{array}{c}\text { L1 de BPV-1 } \\
\text { Recombinante (diluída em } \\
\text { PBS)+ Extrato aquoso de } \\
\text { Agave Sisalana (diluída } \\
\text { em PBS e DMSO 2\%) }\end{array}$ & $1 \mathrm{ug} / \mathrm{mL}+50 \mathrm{gL} / \mathrm{mL}$ \\
\hline DMSO & DMSO 2\%+PBS & $10 \mathrm{uL} / \mathrm{mL}$ \\
\hline
\end{tabular}

Após $44 \mathrm{~h}$ de início do procedimento, as amostras coletadas foram tratadas com $6 \mu \mathrm{L}$ de citocalasina B, diluída em DMSO, na concentração de $6 \mu \mathrm{g} / \mathrm{mL}$, para impedir a citocinese, conforme Araldi et al (2015). As amostras foram incubadas por $72 \mathrm{~h}$ e então foi adicionado $0,5 \mathrm{~mL}$ de fixador Carnoy (3:1 metanol-ácido acético) por $5 \mathrm{~min}$ a temperatura ambiente. Os tubos foram centrifugados por $10 \mathrm{~min}$ a $1.000 \mathrm{rpm}$. O sobrenadante foi descartado por inversão. Foram adicionados $5 \mathrm{~mL}$ de fixador Carnoy por tubo. O material foi cuidadosamente homogeneizado com auxílio de pipetas Pasteur descartáveis para evitar eventuais contaminações. Os tubos foram centrifugados por 10 minutos a $1.000 \mathrm{rpm}$, descartando-se o sobrenadante. 0 procedimento foi repetido por três vezes.

Após a última centrifugação, o material foi aspirado e transferido para lâminas previamente limpas com álcool $70^{\circ}$. As lâminas foram secas em temperatura ambiente 
overnight, fixadas em metanol absoluto e coradas com solução de $2 \%$ de Giemsa em tampão PBS pH 6, 8 por 8 min. O material foi lavado três vezes em água destilada por 3 min. As lâminas foram montadas com Entelan (Merck, Alemanha) e analisadas em microscópio binocular de luz Primo Star (Zeiss, Alemanha) com objetiva de $100 \mathrm{X}$.

O método prevê a análise de 1.000 células por lâmina, observando-se a frequência de linfócitos micronucleados. As análises do TMBC em sague periférico é realizada avaliando a frequência de formação de micronúcleos $\left(\mathrm{MN}_{\mathrm{r} 0}=\mathrm{a} / \mathrm{b}\right.$, onde: $\mathrm{a}$ número de linfócitos com MN e b - número total de linfócitos). Com base no número de células micronucleadas foi realizado um histograma através do software Excel.

\subsection{Teste do Micronúcleo com Bloqueio de Citocinese em Cultivo Celular}

O TMNBC foi, também, realizado em linhagens de células epiteliais Vero não infectadas pelo BPV (FLORES \& YAMAGUCHI, 2008). Tais células imortalizadas, disponíveis comercialmente, fazem parte do acervo biológico do Laboratório de Parasitologia do Instituto Butantan.

As células foram cultivadas em placas de Petri, em meio mínimo (MEM) suplementado com $10 \%$ de soro fetal bovino, em estufa a $37^{\circ} \mathrm{C}$ e atmosfera de $5 \%$ de $\mathrm{CO}_{2}$.

Cultura de células: Foram estabelecidas oito culturas tratadas de acordo com a tabela 3. As substâncias foram adicionadas e após $1 \mathrm{~h}$ foram adicionados $6 \mu \mathrm{g} / \mathrm{mL}$ de Cyt-B. O material foi incubado por 48 horas, já que o tempo de duplicação celular para a linhagem empregada é de 24 horas, garantindo assim, dois ciclos de replicação.

Após a incubação, o meio foi removido com pipeta estéril. As placas foram lavadas com $2 \mathrm{~mL}$ de $\mathrm{PBS}$ a $37^{\circ} \mathrm{C}$, o qual foi descartado por inversão. Foram adicionados $2 \mathrm{~mL}$ de solução de tripsina-EDTA a $37^{\circ} \mathrm{C}$. As placas foram incubadas

por 5 minutos. Após este tempo, o material foi aspirado e transferido para o tubo de Falcon contendo o meio inicialmente removido, permitindo a inativação da tripsina. $O$ material foi centrifugado por 5 minutos a $1.000 \mathrm{rpm}$. O pellet celular foi coletado e transferido para lâminas previamente lavadas, realizando-se esfregaço. As lâminas foram montadas empregando Entellan (Merck, Alemanha). O material foi analisado em microscópio binocular Primo Star (Zeiss, Alemanha) com objetiva de $100 \mathrm{X}$. 
Foram analisadas 1.000 células por lâmina. As análises do TMN em células Vero foram realizadas avaliando a frequência de formação de micronúcleos $\left(\mathrm{MN}_{\mathrm{r} 0}=\right.$ a/b, onde: a - número de células com MN e b - número total de células). Com base no número de células micronucleadas foi realizado um histograma através do software Excel.

\subsection{Ensaio cometa (EC) em células sanguíneas}

O EC foi empregado para analisar o potencial mutagênico em células sanguíneas.

Pré-preparo das lâminas: Lâminas de 26 X 76 mm foram imersas em bécker contendo solução de agarose de ponto normal de fusão (NMA - normal melting

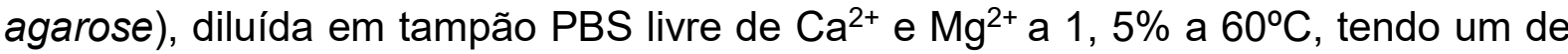
seus lados limpos com papel toalha. As lâminas permaneceram overnight em temperatura ambiente, na posição horizontal, para a completa secagem da agarose.

Tratamento das amostras: O material sanguíneo coletado dos dez bezerros foi fracionado em oito amostras de $200 \mu \mathrm{L}$ cada. As alíquotas foram distribuídas em tubos de polipropileno de 1, $5 \mathrm{~mL}$ contendo $200 \mu \mathrm{L}$ de meio RPMI 1640 e as drogas foram aplicadas aos tubos conforme tabela 3. O material foi incubado por uma hora em estufa a $37^{\circ} \mathrm{C}$, de acordo com Araldi et al. (2015). Após este período, os tubos foram centrifugados a 10.000 RPM por um minuto, descartando-se o sobrenadante. Um volume de $10 \mu \mathrm{L}$ do material centrifugado foi transferido para tubos de polipropileno de $0,2 \mathrm{~mL}$ e acrescido de $75 \mu \mathrm{L}$ de agarose de baixo ponto de fusão (LMA - low melting agorose) a $37^{\circ} \mathrm{C}$. O volume final de $85 \mu \mathrm{L}$ da suspensão celular foi aspirado com auxílio de pipeta e transferido para as lâminas pré-cobertas com NMA a $1,5 \%$.

As lâminas foram cobertas com lamínula e incubadas a $4^{\circ} \mathrm{C}$ por 20 minutos para a solidificação da agarose. Após este tempo, a lamínula foi cuidadosamente removida. As lâminas foram inseridas em um frasco contendo solução de lise gelada (71 mL da solução estoque de 2, $5 \mathrm{M} \mathrm{NaCl}, 100$ mM EDTA, 10 mM Tris-HCl, acrescido de $0,8 \mathrm{~mL}$ de Triton $\mathrm{X}-100$ e $8 \mathrm{~mL}$ de DMSO), permanecendo nesta por uma hora a $4^{\circ} \mathrm{C}$. A partir deste momento, as demais etapas foram realizadas com as luzes do laboratório apagadas para evitar eventuais danos no DNA. 
Eletroforese: Após a lise, as lâminas foram lavadas em PBS por cinco minutos. O material foi transferido para cuba horizontal, tendo sido adicionado o tampão de eletroforese (300 mM NaOH, 1 mM EDTA, pH > 13, 0). O material permaneceu imerso no tampão por 40 minutos para a remoção das histonas. Após este período, foi iniciada a corrida eletroforética nas seguintes condições: $24 \mathrm{~V}(0,74 \mathrm{~V} / \mathrm{cm}), 300 \mathrm{~mA}$ durante 30 minutos. A cuba eletroforética foi revestida por placas de gelo afim de garantir que o material permanecesse a $4^{\circ} \mathrm{C}$ durante o experimento.

Neutralização: Após a eletroforese, o material foi neutralizado em solução neutralizadora $(400 \mathrm{mM}$ de Tris- $\mathrm{HCl}, \mathrm{pH} 7,5)$ por cinco minutos.

Análise do material: $O$ material foi corado com $20 \mu \mathrm{L}$ de iodeto de propídeo (PI) $4 \mu \mathrm{g} / \mathrm{mL}$ e analisado em microscópio de epifluorescência Axio Scope A1 (Carl Zeiss, Alemanha) no aumento total de $400 \mathrm{X}$. Foram analisados 100 nucleóides por lâmina, no total de 8 lâminas (800 nucleóides) para cada uma das 8 amostras, totalizando 6.400 nucleóides, os quais foram classificados em: 0 (sem dano), 1 (dano intermediário) e 2 (dano máximo), conforme a figura 6.

Análise estatística: Com base no número de nucleóides observados por classe, foi obtido o valor do escore por lâmina, conforme a fórmula:

$$
\Sigma=\left[\left(\mathrm{N}_{\mathrm{c} 0} \times 0\right)+\left(\mathrm{N}_{\mathrm{c} 1} \times 1\right)+\left(\mathrm{N}_{\mathrm{c} 2} \times 2\right)\right]
$$

Onde: $\mathrm{N}_{c 0}$ (número de nucleóides observados na classe 0 ), $\mathrm{N}_{11}$ (número de nucleóides observados na classe 1) e $\mathrm{N}_{\mathrm{c} 2}$ (número de nucleóides observados na classe 2).

Com base nos valores de escores obtidos, foi realizado o teste de KruskalWallis seguido do teste post-hoc de Dunn, ambos com nível de significância de 5\% usando o software GraphPad Prism versão 5 (GraphPad Software, Inc.).

\subsection{Ensaio cometa (EC) em cultivo celular}

Oito frascos de cultura de $25 \mathrm{~cm}^{2}$, contendo $5 \mathrm{~mL}$ de meio mínimo (MEM suplementado com $10 \%$ de soro fetal bovino) com confluência de $80 \%$ de células VERO foram destinados ao ensaio cometa. Foram aplicadas as drogas nos frascos conforme tabela 3 . O material foi incubado em estufa a $37^{\circ} \mathrm{C}$, com atmosfera de $5 \%$ 
de $\mathrm{CO}_{2}$ até atingir confluência de $100 \%$. As células foram lavadas com 2, $0 \mathrm{~mL}$ de PBS estéril e centrifugadas a 10.000 RPM, descartando-se o sobrenadante. O pellet foi homogeneizado com $200 \mu \mathrm{L}$ de PBS. Um volume de $20 \mu \mathrm{L}$ da suspensão celular foi transferido para um tubo de polipropileno de $0,2 \mathrm{~mL}$ e acrescido de $170 \mu \mathrm{L}$ de agarose de baixo ponto de fusão (LMA - low melting point agarose) (Fermentas, Lituânia) a 0, $8 \%$, diluída em PBS, a $37^{\circ} \mathrm{C}$. O material foi homogeneizado e transferido para as lâminas pré-cobertas com agarose NMA a 1,5\% e coberto com lamínula.

As lâminas foram cobertas com lamínula e incubadas a $4^{\circ} \mathrm{C}$ por 20 minutos para a solidificação da agarose. Após este tempo, a lamínula foi cuidadosamente removida. As lâminas foram inseridas em um coply contendo solução de lise gelada (71 mL da solução estoque de 2, $5 \mathrm{M} \mathrm{NaCl}, 100 \mathrm{mM}$ EDTA, $10 \mathrm{mM}$ Tris- $\mathrm{HCl}$, acrescido de $0,8 \mathrm{~mL}$ de Triton $\mathrm{X}$-100 e $8 \mathrm{~mL}$ de DMSO), permanecendo nesta por uma hora a $4^{\circ} \mathrm{C}$. A partir deste momento, as demais etapas foram realizadas com as luzes do laboratório apagadas para evitar eventuais danos no DNA. A eletroforese e a neutralização foram feitas de forma similar ao ensaio com células sanguíneas.

Análise do material: $\mathrm{O}$ material foi corado com $20 \mu \mathrm{L}$ de iodeto de propídeo (PI) $4 \mu \mathrm{g} / \mathrm{mL}$ e analisado em microscópio de epifluorescência Axio Scope A1 (Carl Zeiss, Alemanha) no aumento total de $400 \mathrm{X}$. Foram analisados 50 nucleóides por lâmina, no total de 3 lâminas (150 nucleóides) para cada uma das 8 amostras, totalizando 1.200 nucleóides os quais foram classificados em: 0 (sem dano), 1 (dano intermediário) e 2 (dano máximo), conforme figura 6.

Análise estatística: Com base no número de nucleóides observados por classe, foi obtido o valor do escore por lâmina. Com base nos valores de escores obtidos, foi realizado o teste de Kruskal-Wallis seguido do teste post-hoc de Dunn, ambos com nível de significância de 5\% usando o software GraphPad Prism versão 5 (GraphPad Software, Inc.).

\subsection{Citometria de fluxo: ensaio com Anexina V-PI}

Oito frascos de cultura de $25 \mathrm{~cm}^{2}$, contendo $5 \mathrm{~mL}$ de meio mínimo (MEM suplementado com $10 \%$ de soro fetal bovino) com confluência de $70 \%$ de células VERO foram destinados ao ensaio de Citometria de Fluxo.

As células foram incubadas com as diferentes substâncias testadas (tabela 3) a $37^{\circ} \mathrm{C}$ por 48 horas, tempo necessário para dois ciclos de duplicação. Em seguida, o 
meio foi transferido para tubos Falcon de $15,0 \mathrm{~mL}$ e as células foram lavadas com 2, $0 \mathrm{~mL}$ de PBS estéril e incubadas com 2,0 mL de solução de tripsina / EDTA (Cultilab, Campinas, Brasil) a $37^{\circ} \mathrm{C}$ por cinco minutos para promover a desagregação de monocamada . A suspensão celular foi transferida para o tubo Falcon contendo o meio removido e centrifugado a 1.400 RPM durante cinco minutos, descartando o sobrenadante. O sedimento foi homogeneizado com 1,0 mL de PBS estéril frio e transferido para tubo de polipropileno de $1,5 \mathrm{~mL}$. As células foram centrifugadas a 1.400 RPM durante cinco minutos, descartando o sobrenadante. As células foram homogeneizadas com $100 \mu \mathrm{L}$ de tampão de ligação e incubadas com 5,0 $\mu \mathrm{L}$ de Annexin V-FITC e 5,0 $\mu \mathrm{L}$ de iodeto de propídio $(\mathrm{PI})$ durante 15 minutos à temperatura ambiente. As células foram homogeneizadas com $100 \mu \mathrm{L}$ e, em seguida, centrifugadas a 1.400 RPM durante cinco minutos, descartando o sobrenadante. As células foram homogeneizadas com $100 \mu \mathrm{L}$ de tampão de ligação a frio e analisadas em citometria de fluxo de BD Accuri C6 (BD Biosciences, EUA), utilizando os canais FL1 (Annexin V-FITC) e FL3 (PI). As análises foram realizadas em triplicata, sendo analisados 10.000 eventos. Os dados foram analisados por meio do software BD Accuri C6. A análise estatística foi realizada com base na porcentagem média de células vivas, por meio do teste two-way ANOVA seguido do teste post-hoc Tukey $(\mathrm{P}<0.05)$ usando o software GraphPad Prism versão 5 (GraphPad Software, Inc.).

\subsection{Fracionamento cromatográfico por Cromatografia Líquida de Alta Eficiência (CLAE) do extrato bruto de Agave Sisalana Perrine}

Foram pesados $52,3 \mathrm{mg}$ do extrato hidrolisado e liofilizado, e também do padrão de Saponina Sigma, a seguir foram homogeneizados em $2 \mathrm{~mL}(26,15 \mathrm{mg} / \mathrm{mL})$ de solução aquosa de ácido trifluoracético-TFA 0,05\% e submetidos à Cromatografia Líquida de Alta Eficiência em coluna Júpiter C18 (Phenomenex R.), semi-preparativa, $250 \mathrm{~mm}$ x $10 \mathrm{~mm}$ (Resina 10 ųm x $300 \AA$ A), sistema UFLC Shimadzu modelo Proeminence. A coluna foi previamente equilibrada com solvente A (TFA0,05\%) e as eluições foram realizadas em gradiente linear $0-80 \%$ de acetonitrila acidificada (ACN/TFA) durante 80 minutos, com fluxo de vazão de $2 \mathrm{~mL} / \mathrm{min}$. A separação foi realizada a temperatura constante e a absorbância monitorada em 225 e $280 \mathrm{~nm}$. 
As frações correspondentes aos picos foram coletadas manualmente e concentradas em centrífuga a vácuo (Savant Instrument Inc.), liofilizadas (Liofilizador Epsilon 2_6D LSC, Christ, Alemanha) e armazenadas a $-80^{\circ} \mathrm{C}$ até o momento da realização dos ensaios.

\subsection{Ensaio cometa (EC) em cultivo celular das frações obtidas por Cromatografia Líquida de Alta Eficiência (CLAE)}

As frações escolhidas para análise de atividade genotóxica foram aquelas cujos picos eluíam em tempos de retenção semelhantes, comparando amostra e padrão. O padrão utilizado foi a saponina comercial obtida da casca de Quillaja saponaria (Sigma, Germany, referência S4521), por ser o único padrão disponível atualmente no mercado.

Essa análise foi feita com o intuito de isolar e identificar a substância que, possivelmente, confere genotoxidade na composição deste composto.

Dezesseis frascos de cultura de $25 \mathrm{~cm}^{2}$, contendo $5 \mathrm{~mL}$ de meio mínimo (MEM suplementado com $10 \%$ de soro fetal bovino) com confluência de $80 \%$ de células VERO foram destinados ao ensaio cometa. As frações obtidas foram reconstituídas em $300 \mu \mathrm{L}$ de DMSO $2 \%$, e $10 \mu \mathrm{L}$ foram aplicados nos frascos, bem como o controle positivo Ciclofosfamida $50 \mu \mathrm{L} / \mathrm{mL}$ e o diluente DMSO $2 \%$. O material foi incubado em estufa a $37^{\circ} \mathrm{C}$, com atmosfera de $5 \%$ de $\mathrm{CO}_{2}$ até atingir confluência de $100 \%$. As células foram lavadas com 2, $0 \mathrm{~mL}$ de PBS estéril e centrifugadas a 10.000 RPM, descartando-se o sobrenadante. O pellet foi homogeneizado com $200 \mu \mathrm{L}$ de PBS. Um volume de $20 \mu \mathrm{L}$ da suspensão celular foi transferido para um tubo de polipropileno de $0,2 \mathrm{~mL}$ e acrescido de $170 \mu \mathrm{L}$ de agarose de baixo ponto de fusão (LMA - low melting point) (Fermentas, Lituânia) a $0,8 \%$, diluída em PBS, a $37^{\circ} \mathrm{C}$. O material foi homogeneizado e transferido para as lâminas pré-cobertas com agarose NMA a 1 , $5 \%$ e coberto com lamínula.

As lâminas foram cobertas com lamínula e incubadas a $4^{\circ} \mathrm{C}$ por 20 minutos para a solidificação da agarose. Após este tempo, a lamínula foi cuidadosamente removida. As lâminas foram inseridas em um coply contendo solução de lise gelada (71 mL da solução estoque de 2, $5 \mathrm{M} \mathrm{NaCl}, 100 \mathrm{mM}$ EDTA, $10 \mathrm{mM}$ Tris-HCl, acrescido de $0,8 \mathrm{~mL}$ de Triton $\mathrm{X}-100$ e $8 \mathrm{~mL}$ de DMSO), permanecendo nesta por uma hora a $4^{\circ} \mathrm{C}$. A partir deste momento, as demais etapas foram realizadas com as luzes do 
laboratório apagadas para evitar eventuais danos no DNA. A eletroforese e a neutralização foram feitas de forma similar ao ensaio com células sanguíneas.

Análise do material: $\mathrm{O}$ material foi corado com $20 \mu \mathrm{L}$ de iodeto de propídeo (PI) $4 \mu \mathrm{g} / \mathrm{mL}$ e analisado em microscópio de epifluorescência Axio Scope A1 (Carl Zeiss, Alemanha) no aumento total de 400 X. Foram analisados 100 nucleóides por lâmina, no total de 3 lâminas (300 nucleóides) para cada uma das 16 amostras, totalizando 4.800 nucleóides os quais foram classificados em: 0 (sem dano), 1 (dano intermediário) e 2 (dano máximo), conforme figura 9. Com base no número de nucleóides observados por classe, foi obtido o valor do escore por lâmina. Os três valores de escore por lâmina foram somados para cada amostra para que fosse feita uma comparação de atividade entre o extrato e padrão Sigma. As frações que obtiveram valor de escore mais próximos ao controle positivo foram escolhidas para posterior análise em espectrômetro de massas.

\subsection{Análise e caracterização de substâncias por espectrometria de massa}

A espectrometria de massas foi utilizada para verificar a correspondência molecular das frações de padrão e amostra, com tempos de retenção semelhantes, e que apresentaram ação genotóxica.

O material foi suspenso em $20 \mu \mathrm{L}$ de solução de ácido fórmico a $0,1 \%$ e analisado por cromatografia líquida acoplada a espectrometria de massas (LC-MS / MS). Foi utilizado o equipamento LTQ XL - ETD (Thermo Fisher Scientific, Bremen, Alemanha) acoplado a ao sistema e nano-cromatografia líquida Easy-nLC 1000 (Thermo Fisher Scientific, Bremen, Alemanha).

As frações foram injetadas automaticamente $(18 \mu \mathrm{L})$ em uma pré-coluna C-18 Júpiter C-18 (10 $\mu \mathrm{m}, 100 \mu \mathrm{m} \times 50 \mathrm{~mm}$ ) (Phenomenex) acoplada a uma coluna de fase reversa analítica capilar $\mathrm{C} 18$. Foi utilizado um gradiente linear de 0 a $80 \%$ de acetonitrila / ácido fórmico a 0,1\% durante 30 minutos a um fluxo e $140 \mathrm{~nL} / \mathrm{min}$. A fonte de ionização foi operada em modo positivo, que detecta íons carregados positivamente. Os espectros foram coletados e analisados no software Xcalibur 2.0 (Thermo Electron, USA). A deconvolução dos valores $\mathrm{m} / \mathrm{z}$ para obtenção do peso molecular foi realizada no software Mass Analyzer 1.03 (ZHANG \& MARSHALL, 1998). 


\subsection{Coleta das amostras de sangue periférico}

Foram coletados $10 \mathrm{~mL}$ de sangue periférico de dez bovinos (Bos taurus, Simental) com até 2 meses, já que estudos apontam uma correlação de danos no DNA idade-dependente (HEUSER et al., 2008), de acordo com a tabela 4.

Tabela 4 - Dados das amostras de sangue coletadas de recém-nascidos sem manifestações clínicas no dia 05/06/2017.

\begin{tabular}{c|c|c|c}
\hline $\begin{array}{c}\mathbf{N}^{\circ} \text { da } \\
\text { Amostra }\end{array}$ & Nome & SEXO & NASCIMENTO \\
\hline 1 & FAV 11 & MACHO & $13 / 04 / 17$ \\
\hline 2 & FAV 9 & MACHO & $10 / 04 / 17$ \\
\hline 3 & FAV 8 & MACHO & $12 / 04 / 17$ \\
\hline 4 & FAV 13 & FEMEA & $13 / 05 / 17$ \\
\hline 5 & FAV 15 & FEMEA & $23 / 05 / 17$ \\
\hline 6 & FAV 16 & FEMEA & $23 / 05 / 17$ \\
\hline 7 & FAV 14 & FEMEA & $22 / 05 / 17$ \\
\hline 8 & FAV 18 & FEMEA & $30 / 05 / 17$ \\
\hline 9 & FAV 17 & FEMEA & $24 / 05 / 17$ \\
\hline 10 & FAV 19 & MACHO & $01 / 06 / 17$ \\
\hline
\end{tabular}

\subsection{Extração e quantificação de DNA}

O DNA extraído foi quantificado em espectrofotômetro BioPhotometer Plus (Eppendorf, Hamburgo, Alemanha), onde foi realizada a leitura de uma alíquota de 2 $\mu \mathrm{L}$ das respectivas amostras em comprimentos de onda de 230, 260 e $280 \mathrm{~nm}$. A concentração de DNA foi calculada em ng/ $\mu \mathrm{L}$ e o grau de pureza nas razões 260/230 e 260/280 de acordo com a tabela 5.

Tabela 5 - Determinação por espectrofotometro da concentração do DNA das amostras saguíneas coletadas e das diferentes razões em diferentes comprimentos de onda.

\begin{tabular}{llll}
\hline AMOSTRAS & $\mathrm{ng} / \mathrm{\mu L}$ & $\mathrm{R}(260 / 230)$ & $\mathrm{R}(260 / 280)$ \\
\hline 1 & 17 & 1,07 & 1,03 \\
\hline 2 & 27 & 0,93 & 1,08 \\
\hline 3 & 27 & 0,93 & 1,08 \\
\hline 4 & 65 & 1,00 & 1,57 \\
\hline 5 & 70 & 0,82 & 1,39 \\
\hline 6 & 65 & 1,06 & 1,58 \\
\hline 7 & 43 & 0,83 & 1,70 \\
\hline 8 & 37 & 1,32 & 1,26 \\
\hline 9 & 80 & 1,90 & 1,64 \\
\hline 10 & 26 & 3,15 & 1,49 \\
\hline
\end{tabular}




\subsection{Identificação e Tipagem Molecular de BPV nas amostras de sangue periférico}

As amostras de sangue coletadas de dez bezerros foram submetidas à identificação molecular de sequências de DNA viral por meio de PCR. Para tanto, foram empregados três pares de primers específicos (BPV-1, BPV-2 e BPV-4). Os resultados da identificação de sequências de BPV são mostrados na figura 13.

O diagnóstico molecular das dez amostras de sangue periférico revelou a ausência de amplicons para os três diferentes pares de primers empregados. Entretanto, os primers amplificaram as amostras de controle positivo constituídas por genomas de BPV-1, 2 e 4, clonados em bactérias E.coli D5Ha. Nenhum amplicon foi observado nos controles negativos, anulando a possibilidade de contaminações. 
Figura 13 - Imagens de géis de eletroforese mostrando: a integridade do DNA genômico extraído nas 10 amostras.

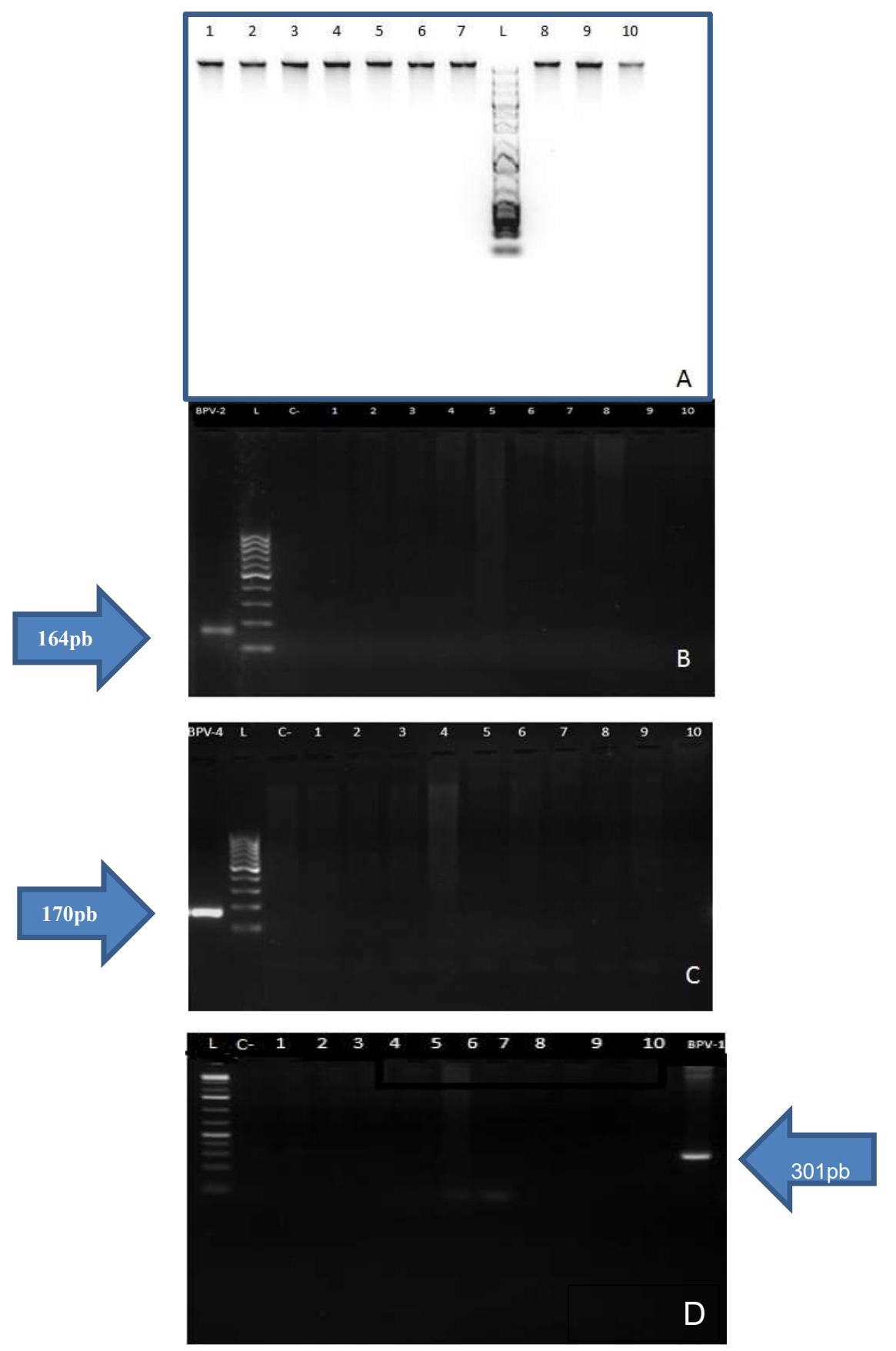

Foi utilizado marcador $1 \mathrm{~Kb}$ DNA Ladder (Invitrogen, Carlsbad, EUA) (A) e constatada a ausência de amplicons empregando primers específicos para BPV-2 (B), BPV-4 (C) e BPV-1 (D). Nas imagens observa-se apenas a presença de amplicons condizentes com os controles positivos. Marcador empregado 100 pb DNA Ladder (Invitrogen, Carlbad, EUA) nas figuras B, C e D. 


\subsection{Ensaio cometa $(E C)$ em células sanguíneas}

Foi estabelecida a análise de oito amostras em cada experimento. Os resultados do ensaio cometa são mostrados na tabela 6

Tabela 6 - Resultados e escores obtidos na análise do potencial mutagênico por ensaio cometa.

Controle negativo (células sanguíneas sem nenhuma substnância aplicada)

\section{Amostra}

$\begin{array}{r} \\ \hline 0 \\ 02 \\ 03 \\ 04 \\ 05 \\ 06 \\ 0 \\ 0 \\ \hline \text { To } \\ \hline\end{array}$

0

$01 \quad 34$
1
Classe 2

$\begin{array}{lllll}03 & 61 & 10 & 29 & 78\end{array}$

$\begin{array}{lllll}04 & 86 & 09 & 05 & 19\end{array}$

$\begin{array}{lllll}05 & 89 & 01 & 07 & 15\end{array}$

$\begin{array}{lllll}06 & 78 & 05 & 16 & 37\end{array}$

$07 \quad 75 \quad 04$

$08 \quad 70 \quad 12$

Total $\quad 537$

Controle positivo $(50 \mu \mathrm{g} / \mathrm{mL}$ de ciclofosfamida)

\begin{tabular}{|c|c|c|c|c|}
\hline Amostra & $0^{\text {Classe }}$ & ${ }_{1}^{\text {Classe }}$ & $2^{\text {Classe }}$ & Escore \\
\hline 01 & 0 & 78 & 22 & 122 \\
\hline 02 & 07 & 74 & 19 & 112 \\
\hline 03 & 01 & 20 & 82 & 184 \\
\hline 04 & 07 & 27 & 66 & 159 \\
\hline 05 & 08 & 14 & 78 & 170 \\
\hline 06 & 0 & 06 & 94 & 194 \\
\hline 07 & 01 & 30 & 69 & 168 \\
\hline 08 & 01 & 29 & 70 & 169 \\
\hline Total & 25 & 278 & 500 & 1278 \\
\hline \multicolumn{5}{|c|}{ Grupo experimental 1 ( $1 \mu \mathrm{g} / \mathrm{ml}$ de L1 recombinante) } \\
\hline Amostra & $0^{\text {Classe }}$ & ${ }_{1}^{\text {Classe }}$ & $2^{\text {Classe }}$ & Escore \\
\hline 01 & 20 & 55 & 25 & 105 \\
\hline 02 & 51 & 20 & 29 & 78 \\
\hline 03 & 09 & 46 & 45 & 136 \\
\hline 04 & 06 & 43 & 52 & 147 \\
\hline 05 & 45 & 0 & 55 & 110 \\
\hline 06 & 85 & 07 & 07 & 21 \\
\hline 07 & 100 & 0 & 0 & 0 \\
\hline 08 & 98 & 02 & 0 & 2 \\
\hline Total & 414 & 173 & 213 & 599 \\
\hline
\end{tabular}

Grupo experimental 2 ( $1 \mu \mathrm{g} / \mathrm{mL}$ de $\mathrm{L} 1$ recombinante $+50 \mathrm{ug} / \mathrm{mL}$ de Saponinas)

Amostra

\begin{tabular}{ccccc}
\hline $\mathbf{0 1}$ & 04 & 73 & 23 & 119 \\
\hline $\mathbf{0 2}$ & 75 & 07 & 17 & 41 \\
\hline $\mathbf{0 3}$ & 33 & 45 & 22 & 89 \\
\hline $\mathbf{0 4}$ & 39 & 44 & 17 & 78 \\
\hline $\mathbf{0 5}$ & 39 & 21 & 41 & 103 \\
\hline $\mathbf{0 6}$ & 54 & 30 & 16 & 62 \\
\hline $\mathbf{0 7}$ & 54 & 03 & 43 & 89 \\
\hline $\mathbf{0 8}$ & $\mathbf{7 1}$ & 14 & 15 & $\mathbf{6 2 5}$ \\
\hline Total & $\mathbf{3 6 9}$ & $\mathbf{2 3 7}$ & $\mathbf{1 9 4}$ & \\
\hline
\end{tabular}

Classe

1
Classe

2 


\begin{tabular}{|c|c|c|c|c|}
\hline \multicolumn{5}{|c|}{ Grupo experimental 3 (10uL/mL de Hidróxido de alumínio) } \\
\hline Amostra & ${ }_{0}^{\text {Classe }}$ & ${ }_{1}^{\text {Classe }}$ & $2^{\text {Classe }}$ & Escore \\
\hline 01 & 73 & 15 & 12 & 39 \\
\hline 02 & 49 & 34 & 17 & 68 \\
\hline 03 & 53 & 12 & 35 & 82 \\
\hline 04 & 69 & 17 & 15 & 47 \\
\hline 05 & 52 & 37 & 11 & 59 \\
\hline 06 & 61 & 22 & 17 & 56 \\
\hline 07 & 69 & 18 & 13 & 44 \\
\hline 08 & 79 & 12 & 09 & 30 \\
\hline Total & 505 & 167 & 129 & 425 \\
\hline \multicolumn{5}{|c|}{ Grupo experimental 4 (50ug/mL de Saponinas) } \\
\hline Amostra & ${ }_{0}^{\text {Classe }}$ & ${ }_{1}^{\text {Classe }}$ & $2^{\text {Classe }}$ & Escore \\
\hline 01 & 48 & 31 & 21 & 73 \\
\hline 02 & 46 & 16 & 38 & 92 \\
\hline 03 & 67 & 25 & 08 & 41 \\
\hline 04 & 68 & 03 & 29 & 61 \\
\hline 05 & 95 & 0 & 05 & 10 \\
\hline 06 & 70 & 22 & 08 & 38 \\
\hline 07 & 62 & 12 & 26 & 64 \\
\hline 08 & 57 & 19 & 24 & 67 \\
\hline Total & 513 & 128 & 159 & 446 \\
\hline \multicolumn{5}{|c|}{$\begin{array}{c}\text { Grupo experimental } 5(1 \mu \mathrm{g} / \mathrm{mL} \text { de } \mathrm{L} 1 \text { recombinante }+10 \mathrm{uL} / \mathrm{mL} \text { de Hidróxido de } \\
\text { alumínio) }\end{array}$} \\
\hline Amostra & ${ }_{0}^{\text {Classe }}$ & ${ }_{1}^{\text {Classe }}$ & $2^{\text {Classe }}$ & Escore \\
\hline 01 & 55 & 10 & 35 & 80 \\
\hline 02 & 61 & 0 & 39 & 78 \\
\hline 03 & 77 & 08 & 15 & 38 \\
\hline 04 & 56 & 14 & 30 & 74 \\
\hline 05 & 45 & 0 & 55 & 110 \\
\hline 06 & 68 & 0 & 32 & 64 \\
\hline 07 & 68 & 0 & 32 & 64 \\
\hline 08 & 60 & 0 & 40 & 80 \\
\hline Total & 490 & 32 & 278 & 588 \\
\hline \multicolumn{5}{|c|}{ Grupo Controle DMSO + PBS (2\%) } \\
\hline Amostra & Classe & Classe & 2 Classe & Escore \\
\hline 01 & 62 & 20 & 18 & 56 \\
\hline 02 & 63 & 19 & 18 & 55 \\
\hline 03 & 63 & 22 & 15 & 52 \\
\hline 04 & 68 & 17 & 15 & 47 \\
\hline 05 & 65 & 26 & 09 & 44 \\
\hline 06 & 67 & 22 & 11 & 44 \\
\hline 07 & 60 & 32 & 08 & 48 \\
\hline 08 & 64 & 20 & 16 & 52 \\
\hline Total & 512 & 178 & 110 & 398 \\
\hline
\end{tabular}

Número de nucleoídes observadas por classe (0 - sem dano, 1 - dano intermediário e 2 - dano máximo), e o respectivo valor do score que demonstra o índice de dano- obtido a partir do somatório do produto do número de nucleóides $(\mathrm{N})$ pelo respectivo valor da classe $(\mathrm{C})$, conforme a fórmula: $\Sigma=$ $(\mathrm{NxC})+\left(\mathrm{NxC}_{1}\right)+\left(\mathrm{NxC}_{2}\right)$ 
Com base nos valores de escores mostrados na tabela 6 , foi realizado o teste de Kruskal-Wallis com nível de significância de 5\%. O teste apontou diferenças estatísticas significantes ( $p=0,0004)$ entre os grupos como mostra a tabela 7 . Baseado neste resultado foi realizado o teste post-hoc de Dunn, também com nível de significância de $5 \%$ representado na figura 8 , o qual revelou diferenças estatísticas significantes entre o grupo controle negativo e positivo, bem como entre controle positivo e o grupo tratado somente com hidróxido de alumínio, saponinas e o diluente DMSO, entretanto, o teste não revelou diferenças significativas entre os grupos controle positivo e o tratado com a combinação da proteína L1 e os adjuvantes, nem tampouco o grupo tratado apenas com a proteína L1 como mostra a tabela 7.

Tabela 7 - Valores estatísticos do teste post-hoc de Dunn obtidos por meio do software GraphPad Prism versão 5 do teste cometa em células sanguíneas

\begin{tabular}{|c|c|c|}
\hline Dunn's Multiple Comparison Test & Difference in rank sum & Significant? $P<0.05$ ? \\
\hline $\mathrm{C}+$ vs $\mathrm{C}-$ & 37.81 & Yes \\
\hline $\mathrm{C}+$ vs S & 34.25 & Yes \\
\hline$C+v s \mathrm{~L} 1+\mathrm{S}$ & 22.50 & No \\
\hline $\mathrm{C}+$ vs $\mathrm{L} 1$ & 26.38 & No \\
\hline $\mathrm{C}+$ vs DMSO & 38.25 & Yes \\
\hline $\mathrm{C}+$ vs $\mathrm{H}$ & 36.25 & Yes \\
\hline $\mathrm{C}+\mathrm{vs} \mathrm{L} 1 \mathrm{H}$ & 23.56 & No \\
\hline C-vs S & -3.563 & No \\
\hline C-vs $\mathrm{L} 1+\mathrm{S}$ & -15.31 & No \\
\hline C-vs L1 & -11.44 & No \\
\hline C-vs DMSO & 0.4375 & No \\
\hline C-vs H & -1.563 & No \\
\hline C-vs L1H & -14.25 & No \\
\hline
\end{tabular}

A comparação dos valores de escores entre os grupos é mostrada na figura 14. 
Figura 14 - Gráfico estatístico de Ensaio cometa em células sanguíneas comparando os valores de escore das amostras tratadas em relação ao controle positivo

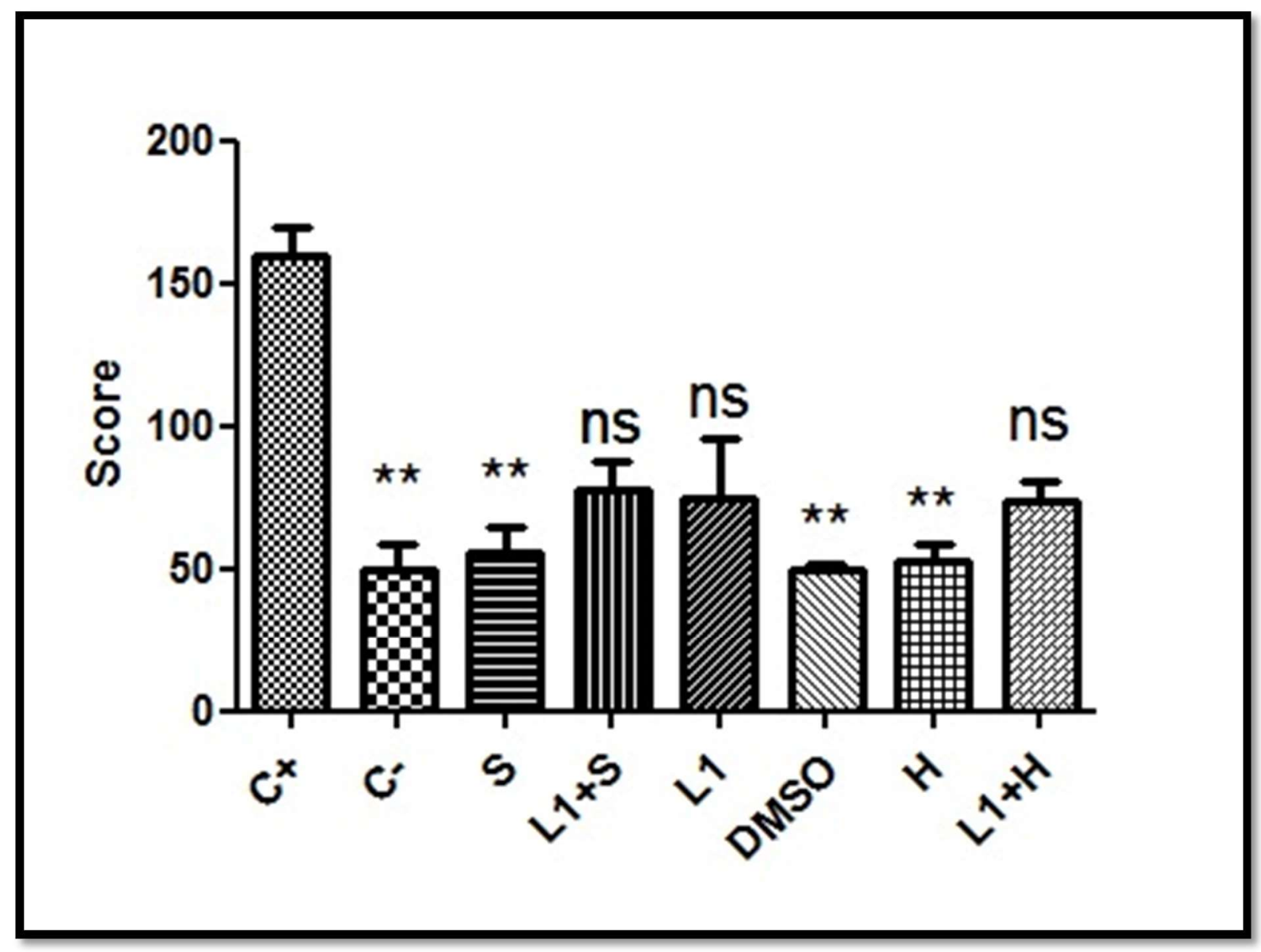

O grupo C-(controle negativo), Saponinas, DMSO e H (Hidróxido de Alumínio) apresentaram diferenças significantes com o grupo comparativo, não demonstrando caráter mutagênico.

Para valor de $P>0,05, N S=$ diferença não significante estatisticamente; $P$ entre 0,01 e $0,5\left(^{*}\right)$ $=$ diferença significante, $\mathrm{P}$ entre 0,001 e $0,01\left({ }^{* *}\right)=$ diferença muito significante, $\mathrm{P}<0,001\left({ }^{* * *}\right)$ $=$ diferença extremamente significante.

\subsection{Teste do Micronúcleo com Bloqueio de Citocinese (TMBC) em Sangue Periférico}

O teste foi feito repetidas vezes e não foi satisfatório, pois não houve número suficiente de células para contagem, já que mais de $80 \%$ estavam hemolisadas, inclusive no controle negativo, o que leva a crer que não é algo relativo a toxidade das substâncias aplicadas. Na figura 15 pode-se observar uma comparação entre células sem a presença de micronúcleos e células micronucleadas. A insuficiência de resultados neste ensaio não foi determinante para a conclusão do trabalho. 
Figura 15 - Análise microscópica do Teste de Micronúcleo em células sanguíneas

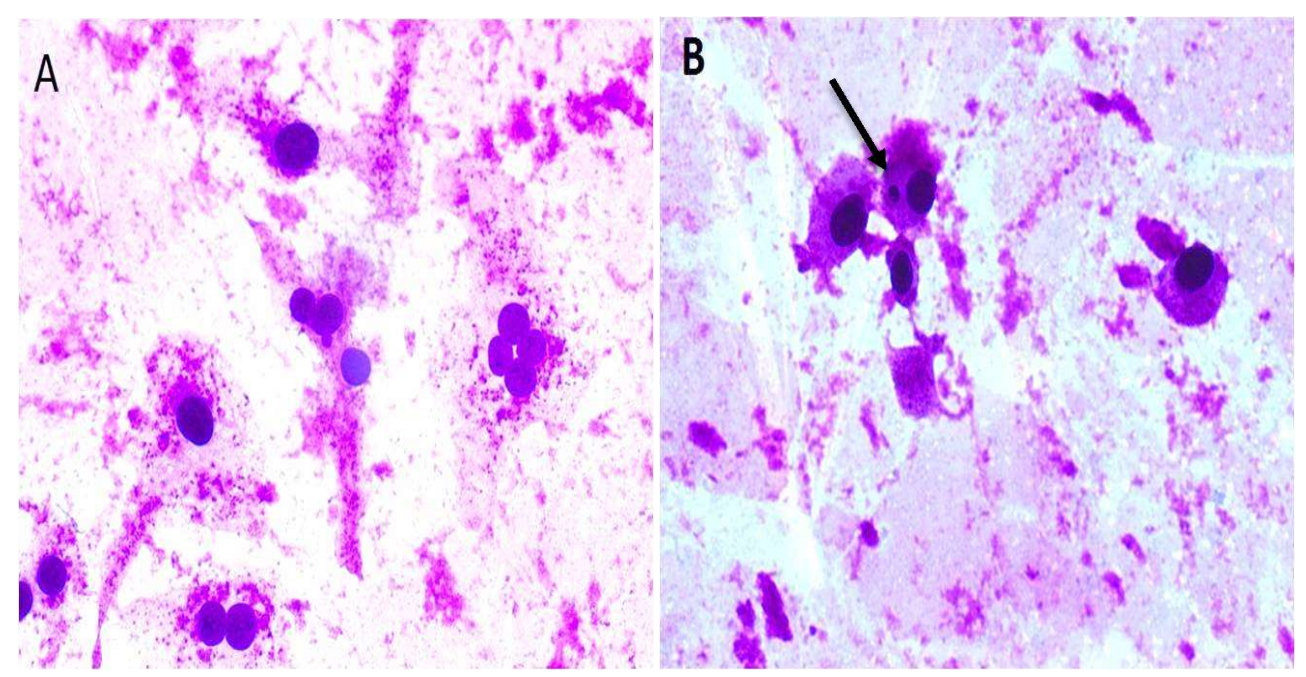

A)Linfócitos sem a presença de micronúcleo; B) Linfócito com micronúcleo.

\subsection{Ensaio cometa (EC) em cultivo celular}

Os resultados observados na análise do potencial mutagênico por ensaio cometa em células Vero são apresentados na tabela 8.

Tabela 8 - Número de nucleoídes observadas por classe (0 - sem dano, 1 - dano intermediário e 2 - dano máximo), em triplicata, e o respectivo valor do score que demonstra o índice de dano- obtido a partir do somatório do produto do número de nucleóides $(\mathrm{N})$ pelo respectivo valor da classe $(\mathrm{C})$, conforme a fórmula: $\Sigma=\left(\mathrm{NxC}_{0}\right)+$ $\left(\mathrm{NxC}_{1}\right)+\left(\mathrm{NxC}_{2}\right)$.

\begin{tabular}{|c|c|c|c|c|}
\hline \multicolumn{5}{|c|}{ Controle negativo (células Vero sem nenhuma substância aplicada) } \\
\hline Amostra & Classe & Classe & Classe & Escore \\
\hline & & & 2 & \\
\hline 01 & 46 & 03 & 01 & 05 \\
\hline 02 & 46 & 01 & 02 & 05 \\
\hline 03 & 48 & 01 & 01 & 03 \\
\hline Total & 140 & 05 & 03 & 13 \\
\hline \multicolumn{5}{|c|}{ Controle positivo (50 $\mathrm{\mu g} / \mathrm{mL}$ de ciclofosfamida) } \\
\hline \multirow[t]{2}{*}{ Amostra } & Classe & Classe & Classe & \multirow[t]{2}{*}{ Escore } \\
\hline & & & 2 & \\
\hline 01 & 02 & 18 & 30 & 78 \\
\hline 02 & 06 & 11 & 33 & 77 \\
\hline 03 & 09 & 11 & 30 & 71 \\
\hline Total & 17 & 40 & 93 & 226 \\
\hline \multicolumn{5}{|c|}{ Grupo experimental 1 ( $1 \mu \mathrm{g} / \mathrm{mL}$ de $\mathrm{L} 1$ recombinante) } \\
\hline Amostra & Classe & Classe & Classe & Escore \\
\hline & & & 2 & \\
\hline 01 & 21 & 10 & 19 & 48 \\
\hline 02 & 22 & 09 & 19 & 47 \\
\hline 03 & 18 & 18 & 14 & 46 \\
\hline Total & 61 & 37 & 53 & 141 \\
\hline
\end{tabular}




\begin{tabular}{|c|c|c|c|c|}
\hline \multicolumn{5}{|c|}{ Grupo experimental $2(1 \mu \mathrm{g} / \mathrm{ml}$ de $\mathrm{L} 1$ recombinante $+50 \mathrm{ug} / \mathrm{mL}$ de Saponinas) } \\
\hline Amostra & Classe & Classe & $2^{\text {Classe }}$ & Escore \\
\hline 01 & 21 & 09 & 20 & 49 \\
\hline 02 & 20 & 10 & 20 & 50 \\
\hline 03 & 22 & 10 & 18 & 46 \\
\hline Total & 63 & 29 & 58 & 145 \\
\hline \multicolumn{5}{|c|}{ Grupo experimental 3 (10uL/mL de Hidróxido de alumínio) } \\
\hline Amostra & Classe & Classe & Classe & \multirow[t]{2}{*}{ Escore } \\
\hline & & & & \\
\hline 01 & 19 & 14 & 17 & 48 \\
\hline 02 & 21 & 10 & 19 & 48 \\
\hline 03 & 21 & 09 & 17 & 42 \\
\hline Total & 61 & 33 & 53 & 138 \\
\hline \multicolumn{5}{|c|}{ Grupo experimental 4 (50ug/mL de Saponinas) } \\
\hline Amostra & Classe & Classe & Classe & \multirow[t]{2}{*}{ Escore } \\
\hline & & & 2 & \\
\hline 01 & 13 & 17 & 20 & 57 \\
\hline 02 & 12 & 18 & 20 & 58 \\
\hline 03 & 08 & 19 & 23 & 65 \\
\hline Total & 33 & 54 & 63 & 180 \\
\hline \multicolumn{5}{|c|}{$\begin{array}{c}\text { Grupo experimental } 5(1 \mu \mathrm{g} / \mathrm{ml} \text { de } \mathrm{L} 1 \text { recombinante }+10 \mathrm{uL} / \mathrm{mL} \text { de Hidróxido de } \\
\text { alumínio) }\end{array}$} \\
\hline Amostra & Classe & Classe & $2^{\text {Classe }}$ & Escore \\
\hline 01 & 19 & 11 & 20 & 51 \\
\hline 02 & 20 & 20 & 20 & 60 \\
\hline 03 & 21 & 10 & 19 & 48 \\
\hline Total & 60 & 41 & 59 & 159 \\
\hline \multicolumn{5}{|c|}{ Grupo Controle DMSO + PBS (2\%) } \\
\hline Amostra & Classe & Classe & Classe & Escore \\
\hline & & & & \\
\hline 01 & 35 & 09 & 07 & 23 \\
\hline 02 & 39 & 07 & 06 & 19 \\
\hline 03 & 38 & 07 & 05 & 17 \\
\hline Total & 112 & 21 & 19 & 59 \\
\hline
\end{tabular}

Com base nos valores de escores mostrados na tabela 8 , foi realizado o teste de Kruskal-Wallis com nível de significância de 5\% como mostra a tabela 9 . O teste apontou diferenças estatísticas significativas $(p=0,0038)$ entre os grupos. Baseado neste resultado foi realizado o teste post-hoc de Dunn, também com nível de significância de 5\%. 
Tabela 9 - Valores estatísticos do teste post-hoc de Dunn obtidos por meio do software GraphPad Prism versão 5 do teste cometa em cultivo celular

\begin{tabular}{l|l|l}
\hline Dunn's Multiple Comparison Test & Difference in rank sum & Significant? $P<0.05 ?$ \\
\hline C+vs C- & 21.00 & Yes \\
\hline C+vs S & 3.667 & No \\
\hline C+vs L1+S & 9.833 & No \\
\hline C+vs H & 12.33 & No \\
\hline C+vs L1 & 12.67 & No \\
\hline C+vs LI+H & 6.500 & No \\
\hline C+vs DMSO & 18.00 & Yes \\
\hline C-vs S & -17.33 & No \\
\hline C-vs L1+S & -11.17 & No \\
\hline C-vs H & -8.667 & No \\
\hline C-vs L1 & -8.333 & No \\
\hline C- vs LI+H & -14.50 & No \\
\hline C-vs DMSO & -3.000 & No \\
\hline
\end{tabular}

O teste revelou diferenças estatísticas significantes entre o grupo controle negativo e positivo, bem como entre esse e o grupo tratado somente com o diluente DMSO, entretanto, o teste não revelou diferenças significantes entre os grupos controle positivo e o tratado com a combinação da proteína L1 e os adjuvantes, que eram os grupos de interesse, nem tampouco com as drogas separadas como mostra a tabela 9.

A comparação dos valores de escores entre os grupos é mostrada na figura 16. 
Figura 16 - Gráfico estatístico de Ensaio cometa em cultivo celular comparando os valores de escore das amostras tratadas em relação ao controle positivo.

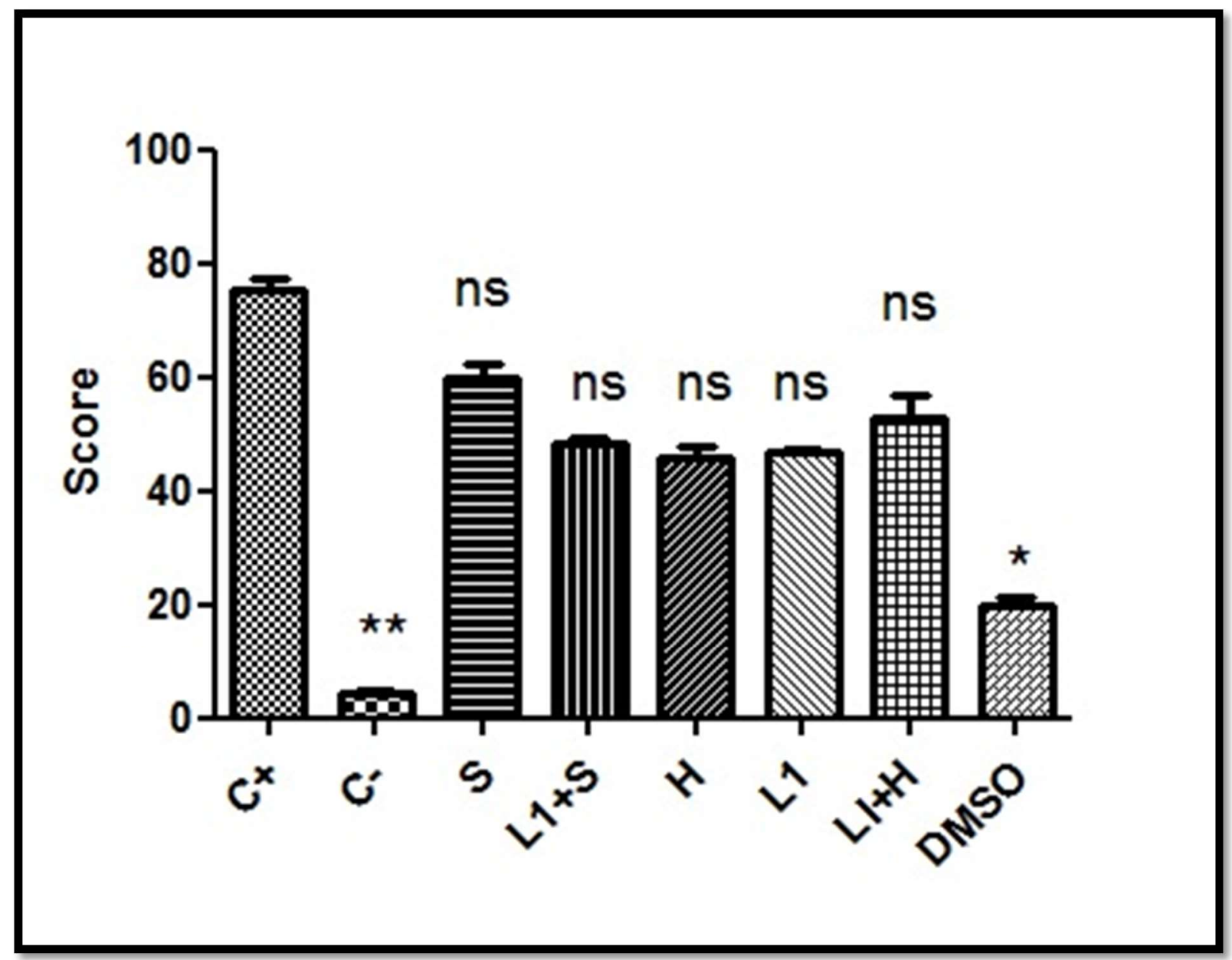

Apenas o grupo C- (controle negativo) e DMSO apresentaram diferenças significantes com o grupo comparativo $\mathrm{C}+$ (controle positivo), os demais apresentaram caráter mutagênico com diferença não significativa em relação ao $C+$. Para valor de $P>0,05$, NS= diferença não significante estatisticamente; $P$ entre 0,01 e $0,5\left({ }^{*}\right)=$ diferença significante, $P$ entre 0,001 e $0,01\left(^{* *}\right)=$ diferença muito significante, $P<0,001\left({ }^{* * *}\right)=$ diferença extremamente significante.

\subsection{Teste do Micronúcleo com Bloqueio de Citocinese em Cultivo Celular}

Foram analisadas 1.000 células por lâmina. As análises do TMN em células Vero foram realizadas avaliando a frequência de formação de micronúcleos $\left(\mathrm{MN}_{\mathrm{r} 0}=\right.$ a/b, onde: a - número de céulas com $\mathrm{MN}$ e b - número total de células).

Os valores encontrados no teste de micronúcleos encontram-se na tabela 10. 
Tabela 10 - Quantidade de micronúcleos encontrados por lâmina e frequência calculada.

\begin{tabular}{c|c|c}
\hline \multicolumn{1}{c|}{ Amostra } & \multicolumn{1}{|c}{ NodeMicronúcleos $^{\mathbf{M N}_{\mathbf{r} \mathbf{0}}}$} \\
\hline C+ & 691 & 0,691 \\
\hline C- & 77 & 0,077 \\
\hline Hidróxido de Alumínio & 148 & 0,148 \\
\hline $\begin{array}{c}\text { Llumínio } \\
\text { L1+Hidróxido de }\end{array}$ & 176 & 0,176 \\
\hline Saponina & 106 & 0,106 \\
\hline L1+Saponina & 226 & 0,226 \\
\hline DMSO & 266 & 0,266 \\
\hline
\end{tabular}

Com base no número porcentual de células micronucleadas foi realizado um histograma comparativo através do software Excel (Figura 17).

Figura 17 - Histograma comparativo das porcentagens de micronúcleos contabilizados entre as amostras com os 8 tratamentos diferentes em células Vero.

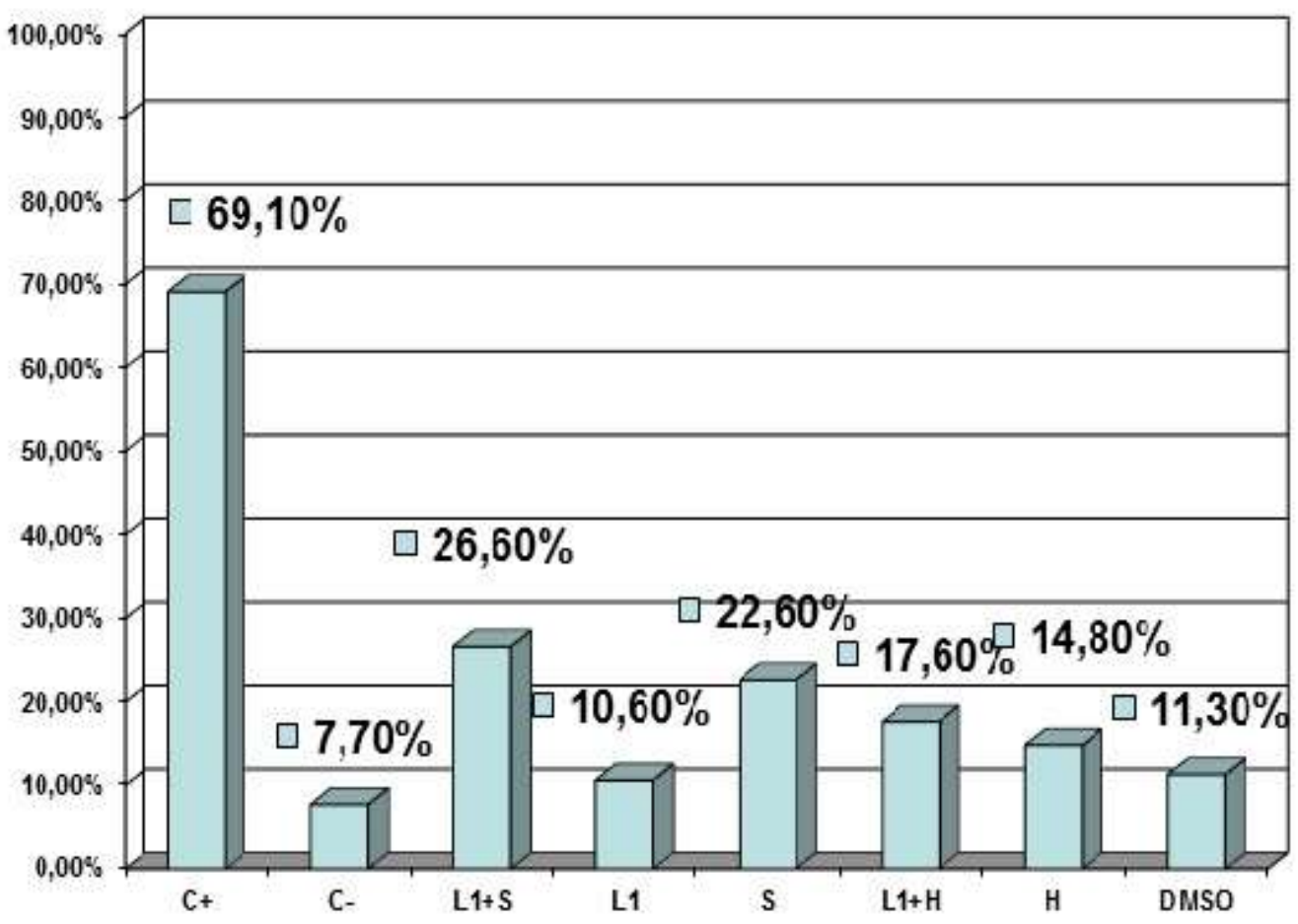


A análise deste gráfico demonstra que $7,7 \%$ de micronúcleos encontrados no controle negativo de um total de 1.000 células analisadas fazem parte do metabolismo basal da célula, e sendo assim, foi subtraído esse valor das demais porcentagens, sendo constatado para a combinação de L1 com saponinas um acréscimo de 18, 9\% de micronúcleos ao controle negativo e 9,9\% ao aplicar a combinação de L1 com Hidróxido de Alumínio, quase o dobro de acréscimo de micronúcleos.

Os valores aproximam-se com a somatória das porcentagens de micronúcleos de drogas separadas, sendo 2,9\% para L1, 14,9\% para saponinas, 7,1\% para Hidróxido de Alumínio e 3,6\% para DMSO. Nenhum valor aproximou-se do controle positivo.

\subsection{Citometria de fluxo: ensaio com Anexina V-PI}

Os dados foram analisados por meio do software BD Accuri C6. A análise estatística foi realizada com base na porcentagem média de células vivas, por meio do teste two-way ANOVA seguido do teste post-hoc Tukey $(P<0,05)$ usando o software GraphPad Prism versão 5 (GraphPad Software, Inc.) conforme figura 18. 
Figura 18- Gráfico estatístico comparando as médias com desvio padrão de células viáveis das amostras tratadas em relação ao controle negativo

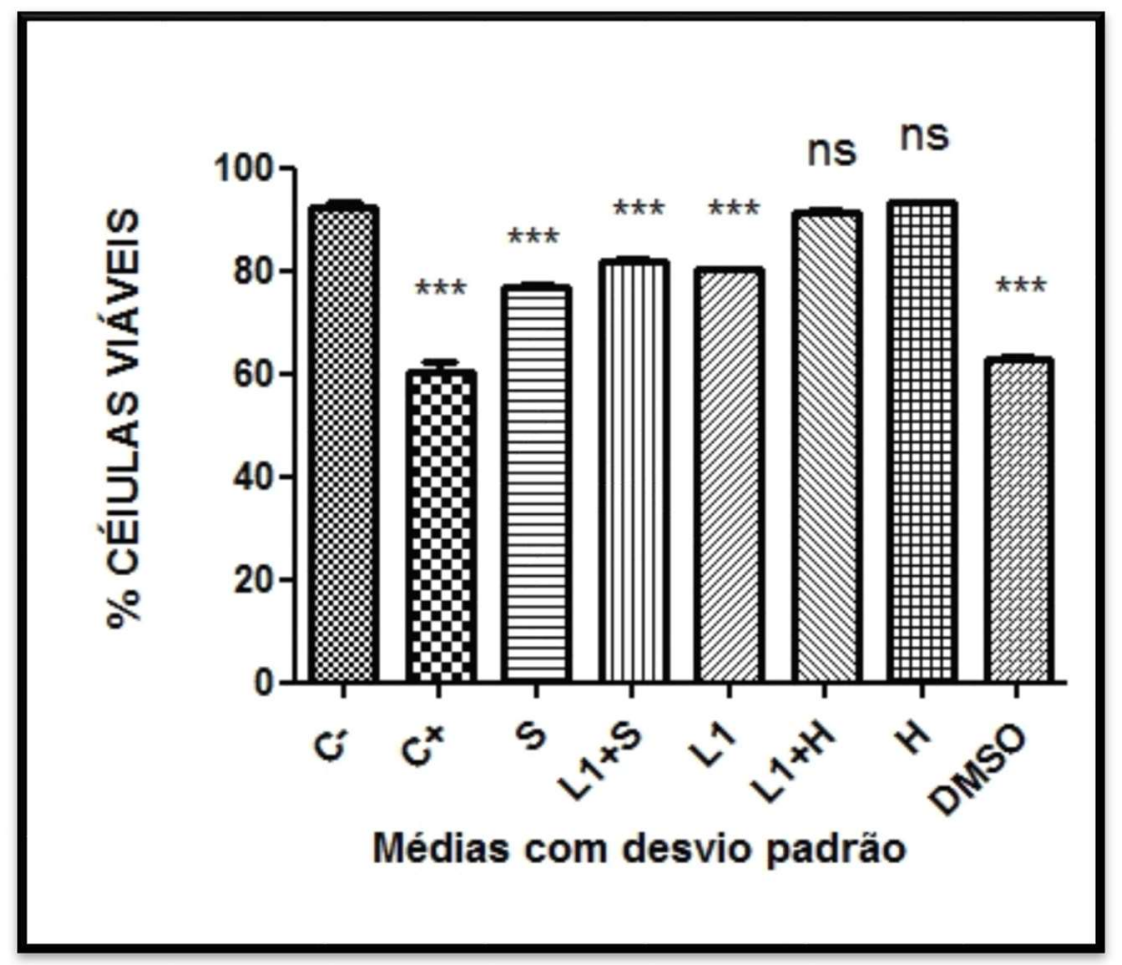

Apenas o grupo $\mathrm{H}$ e $\mathrm{L} 1+\mathrm{H}$ não apresentaram diferenças significantes com o grupo C(controle negativo), caracterizando-os como não mutagênicos neste teste. Para valor de $\mathrm{P}>$ $0,05, \mathrm{NS}=$ diferença não significante estatisticamente; $\mathrm{P}$ entre 0,01 e $0,5\left(^{*}\right)=$ diferença significante, $\mathrm{P}$ entre 0,001 e $0,01\left(^{* *}\right)=$ diferença muito significante, $\left.\mathrm{P}<0,001{ }^{(* *}\right)=$ diferença extremamente significante.

A análise estatística foi realizada com base na porcentagem média de células vivas. O teste two-way ANOVA seguido do teste post-hoc Tukey apontou diferenças estatísticas significantes $(p<0,0001)$ entre os grupos, também com nível de significância de $5 \%$.

Todos os valores de médias apresentaram altas diferenças significantes em relação às células viáveis com o controle negativo com exceção para o conjugado de proteína L1 com Hidróxido de Alumínio e o Hidróxido de Alumínio quando aplicado sozinho que apresentaram valores superiores ao controle negativo.

A figura 19 mostra um gráfico em dot plot do cruzamento entre os eixos de fluorescência de anexina V-FITC e PI onde a população celular viável está representada no quadrante inferior esquerdo (Annexin V-PI-), as células apoptóticas precoces no quadrante inferior direito (Annexin $\mathrm{V}+\mathrm{Pl}$-), as células apoptóticas tardias/necróticas no quadrante superior direito (Annexin $\mathrm{V}+\mathrm{PI}+$ ), as células mortas (Anexin $\mathrm{V}-\mathrm{PI}+$ ) no quadrante superior esquerdo. 
Figura 19 - Gráfico em dot plot dos dados analisados em citometria de fluxo com Anexina-PI por meio do software BD Accuri C6 das células Vero tratadas de acordo com a Tabela $3 \mathrm{com}$ base na porcentagem média de células vivas, por meio do teste two-way ANOVA seguido do teste post-hoc Tukey $(P<0.05)$ usando o software GraphPad Prism versão 5 (GraphPad Software, Inc.).

$\overline{2}$
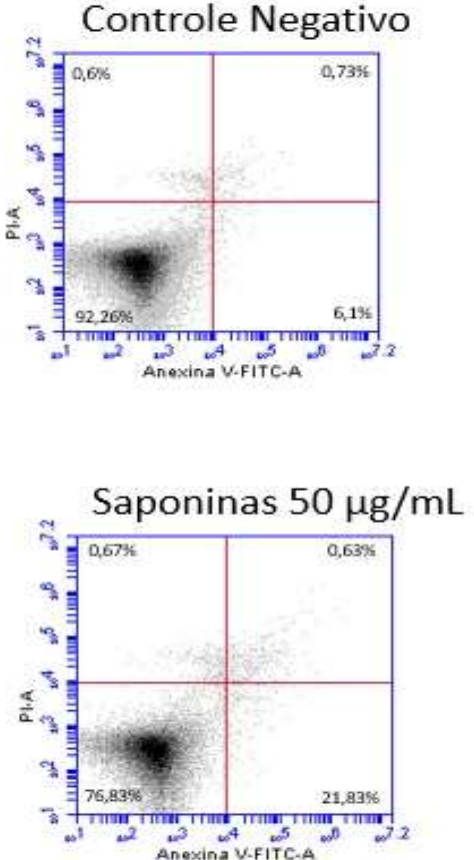
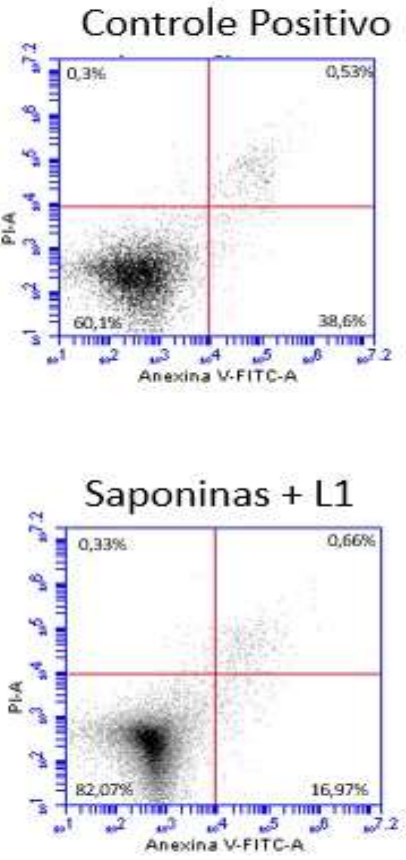
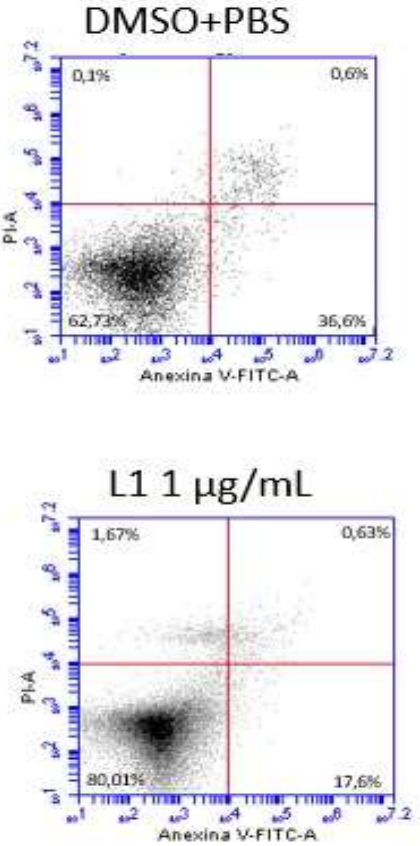
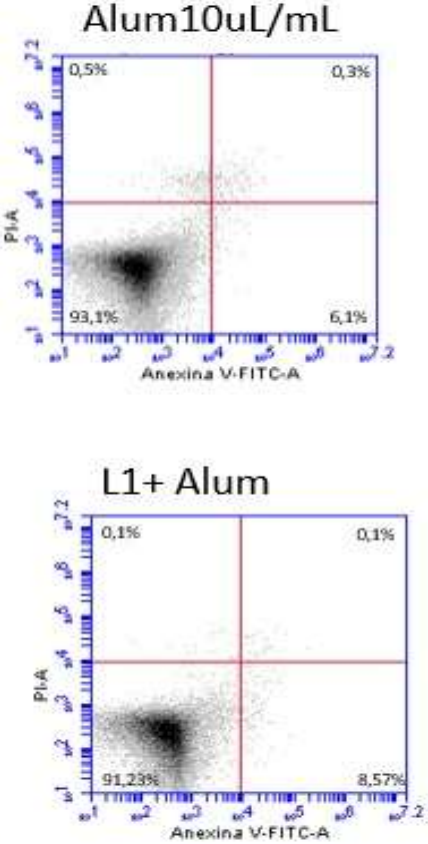

$$
x_{72}
$$

Annexin V - FITC 
Na figura 20 os dados obtidos das triplicatas estão representados em gráfico estatístico com base na porcentagem média de células em cada fase e desvio padrão, por meio do teste two-way anova seguido do teste post-hoc bonferroni $(p<0,05)$ usando o software graphpad prism versão 5 (grandpad software, inc.).

Figura 20 - Gráfico estatístico dos dados analisados das células vero tratadas de acordo com a tabela 3 em comparação as células sem tratamento (C-).

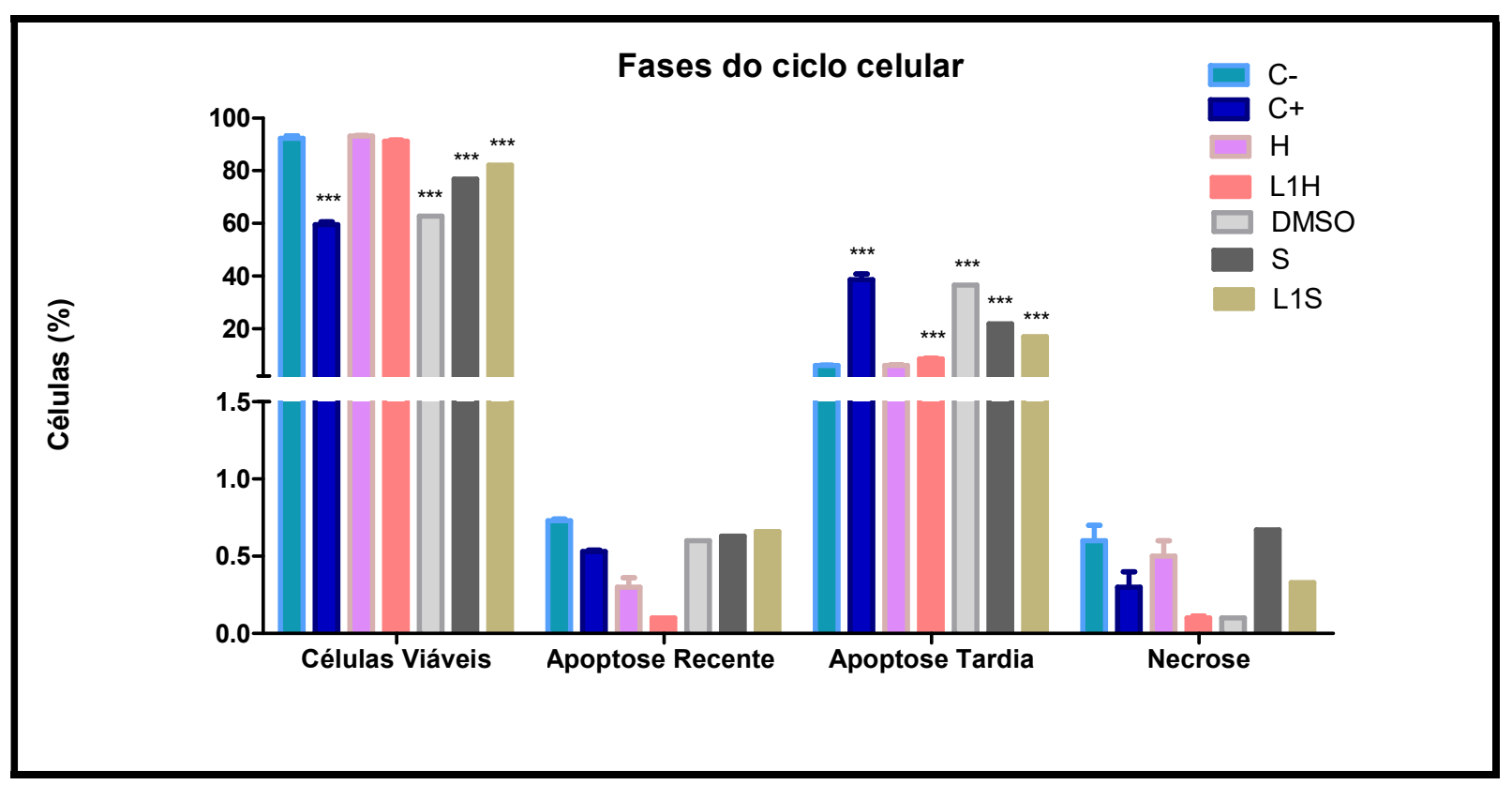

Dados obtidos por meio do software BD Accuri C6 das células Vero tratadas de acordo com a tabela 3 em comparação as células sem tratamento (C-). Com base na porcentagem média de células distribuídas em cada fase do ciclo celular e desvio padrão realizou-se o teste twoway ANOVA seguido do teste post-hoc Bonferroni $(p<0,05)$ usando o software graphpad prism versão 5 (GrandPad Software, Inc.).

Para valor de $P>0,05, N S=$ diferença não significante estatisticamente; $P$ entre 0,01 e $0,5\left(^{*}\right)=$ diferença significante, $\mathrm{P}$ entre 0,001 e $0,01\left(^{* *}\right)=$ diferença muito significante, $\mathrm{P}<$ $\left.0,001{ }^{* * *}\right)=$ diferença extremamente significante. 


\subsection{Isolamento de substâncias por fracionamento cromatográfico}

O isolamento das substâncias presentes no extrato de saponinas e no padrão teve por objetivo fracionar e identificar por CLAE quais frações eram eluídas nas duas amostras em tempos de retenção semelhantes, para que suas genotoxidades fossem analisadas posteriormente e caracterizadas por espectrometria de massas.

Esta etapa resultou na separação e coleta manual de 21 frações conforme os gráficos da figura 21.

Com base nestes gráficos gerados foram coletadas 21 frações e escolhidas 13 , sendo 7 do padrão e 6 do extrato (indicadas com seta na figura 21), entre o minuto 28 e 42 das corridas, gradiente $0-80 \%$ analisando a semelhança entre picos e tempos de retenção. 
Figura 21 - A: Perfil cromatográfico do Padrão Saponinas Sigma.

B: Perfil cromatográfico da amostra de extrato Saponina.
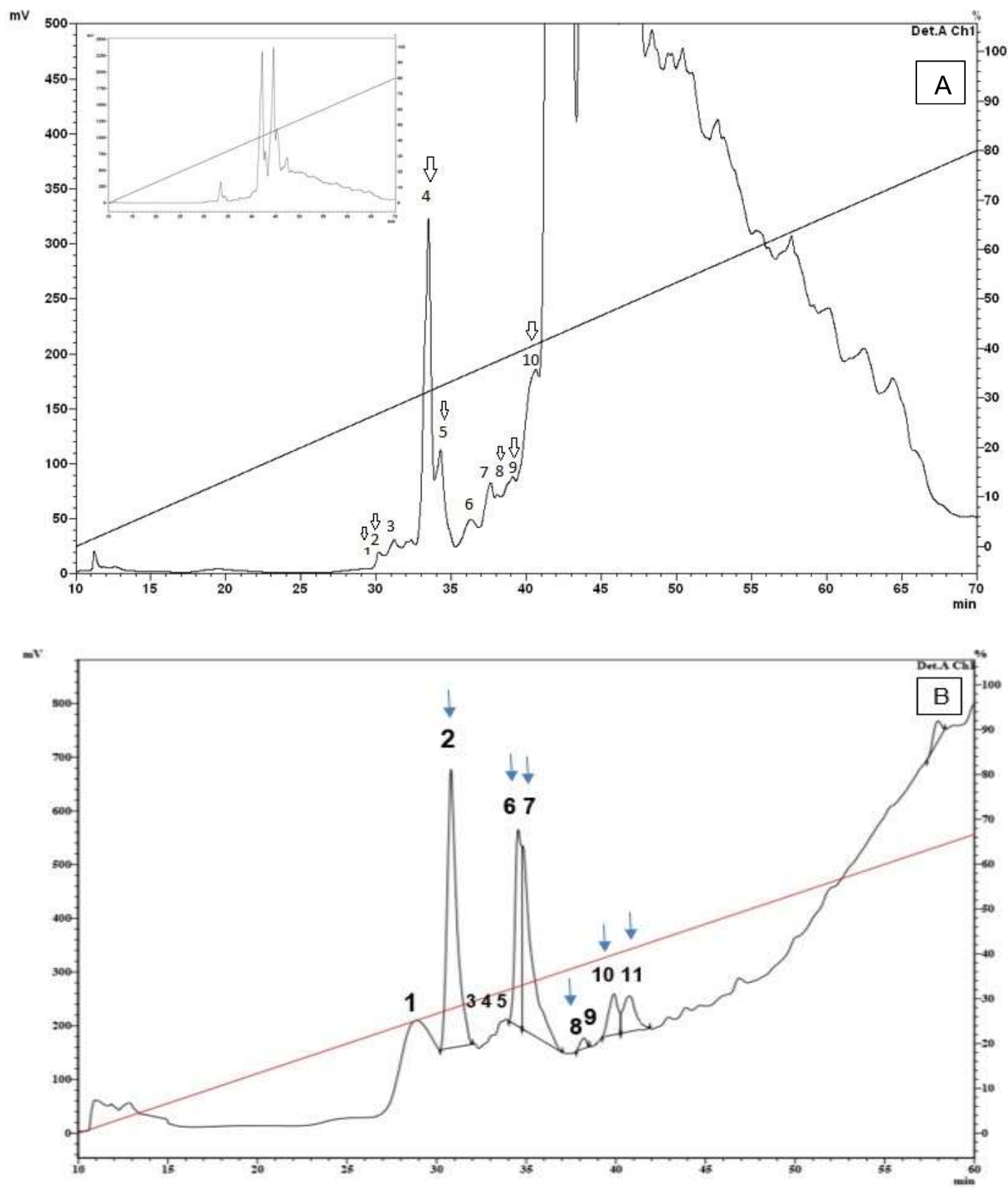

Fonte: Imagens obtidas por meio de análise cromatográfica em sistema UFLC Shimatzu, modelo Proeminence.Foram eluídas 21 frações, as quais foram coletadas manualmente e selecionadas 13 (indicadas em seta). $O$ fracionamento do material foi realizado em coluna de fase reversa semi-preparativa Júpiter C18 (250 mm x $10 \mathrm{~mm}$, Phenomenex) com gradiente linear de 0 a $80 \%$ acetonitrila em água acidificada por 60 minutos, num fluxo de $2 \mathrm{~mL} / \mathrm{min}$. A absorbância foi monitorada em 225 e $280 \mathrm{~nm}$. 
5.10. Ensaio cometa (EC) em cultivo celular das frações obtidas por Cromatografia Líquida de Alta Eficiência (CLAE)

Todas as frações eluídas e selecionadas foram submetidas a um screening de atividade para avaliar sua ação genotóxica por ensaio cometa (tabela 11).

Tabela 11 - Número de nucleoídes observados por classe (0 - sem dano, 1 - dano intermediário e 2 - dano máximo), e o respectivo valor do score que demonstra 0 índice de dano- nas frações obtidas por HPLC- a partir do somatório do produto do número de nucleóides $(\mathrm{N})$ pelo respectivo valor da classe $(\mathrm{C})$, conforme a fórmula: $\Sigma$ $=\left(\mathrm{NxC}_{0}\right)+\left(\mathrm{NxC}_{1}\right)+\left(\mathrm{NxC}_{2}\right)$.

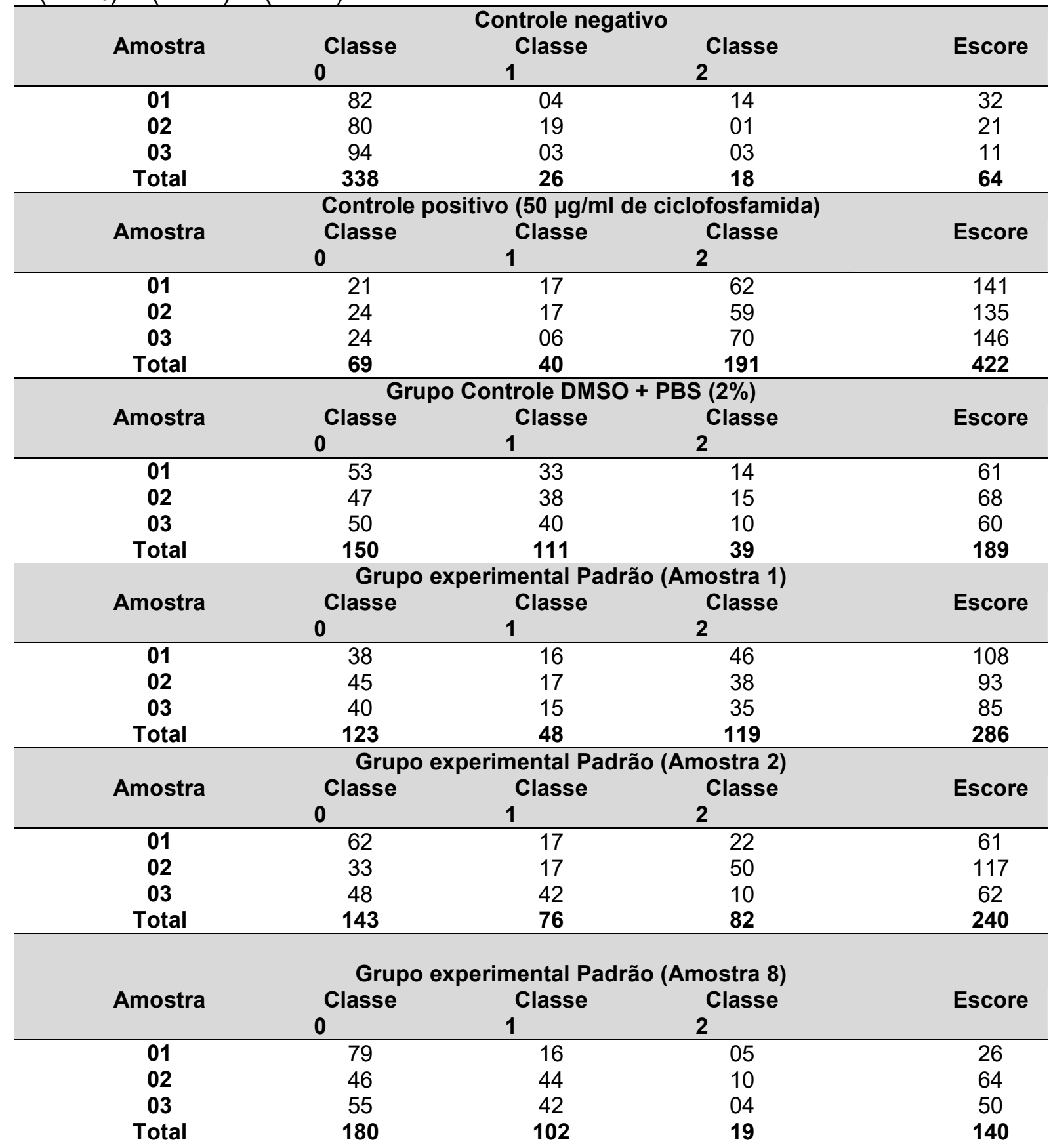




\begin{tabular}{|c|c|c|c|c|}
\hline \multicolumn{5}{|c|}{ Grupo experimental Padrão (Amostra 9) } \\
\hline \multirow[t]{2}{*}{ Amostra } & \multirow{2}{*}{$\begin{array}{l}\text { Classe } \\
0\end{array}$} & \multirow{2}{*}{${ }_{1}^{\text {Classe }}$} & \multirow{2}{*}{$2^{\text {Classe }}$} & \multirow[t]{2}{*}{ Escore } \\
\hline & & & & \\
\hline 01 & 66 & 02 & 31 & 64 \\
\hline 02 & 65 & 10 & 25 & 60 \\
\hline 03 & 73 & 09 & 18 & 45 \\
\hline Total & 204 & 21 & 74 & 214 \\
\hline \multicolumn{5}{|c|}{ Grupo experimental Padrão (Amostra 10) } \\
\hline \multirow[t]{2}{*}{ Amostra } & \multirow{2}{*}{$0^{\text {Classe }}$} & Classe & \multirow{2}{*}{$2^{\text {Classe }}$} & \multirow[t]{2}{*}{ Escore } \\
\hline & & & & \\
\hline 01 & 46 & 09 & 15 & 39 \\
\hline 02 & 27 & 08 & 33 & 74 \\
\hline 03 & 12 & 03 & 12 & 27 \\
\hline Total & 85 & 20 & 60 & 140 \\
\hline \multicolumn{5}{|c|}{ Grupo experimental Padrão (Amostra 5) } \\
\hline \multirow[t]{2}{*}{ Amostra } & \multirow{2}{*}{$\begin{array}{l}\text { Classe } \\
0\end{array}$} & \multirow{2}{*}{ Classe } & \multirow{2}{*}{$2^{\text {Classe }}$} & \multirow[t]{2}{*}{ Escore } \\
\hline & & & & \\
\hline 01 & \multirow{4}{*}{$\begin{array}{c}128 \\
85 \\
58 \\
\mathbf{2 7 1} \\
\end{array}$} & 24 & 48 & 120 \\
\hline 02 & & 10 & 05 & 20 \\
\hline 03 & & 38 & 04 & 46 \\
\hline Total & & 72 & 57 & 286 \\
\hline & Grup & mental $\mathrm{Pa}$ & mostra 4) & \\
\hline Amostra & Classe & Classe & Classe & Escore \\
\hline & & 1 & 2 & \\
\hline 01 & 46 & 21 & 33 & 87 \\
\hline 02 & 44 & 45 & 09 & 63 \\
\hline 03 & 51 & 32 & 17 & 66 \\
\hline Total & 141 & 98 & 59 & 216 \\
\hline & Grup & mental $\mathrm{AE}$ & mostra 2) & \\
\hline Amostra & Classe & Classe & Classe & Escore \\
\hline & 0 & & 2 & \\
\hline 01 & 51 & 21 & 28 & 77 \\
\hline 02 & 23 & 33 & 44 & 121 \\
\hline 03 & 17 & 33 & 50 & 133 \\
\hline Total & 91 & 87 & 122 & 331 \\
\hline & Grup & mental $\mathrm{AE}$ & mostra 6) & \\
\hline Amostra & Classe & Classe & Classe & Escore \\
\hline & & 1 & 2 & \\
\hline 01 & 48 & 14 & 38 & 90 \\
\hline 02 & 46 & 09 & 45 & 99 \\
\hline 03 & 63 & 05 & 32 & 69 \\
\hline Total & 157 & 28 & 115 & 258 \\
\hline & Grup & mental $\mathrm{AE}$ & mostra 7) & \\
\hline Amostra & Classe & Classe & Classe & Escore \\
\hline & & & & Lour \\
\hline 01 & 37 & 10 & 53 & 116 \\
\hline 02 & 15 & 45 & 40 & 125 \\
\hline 03 & 25 & 33 & 42 & 117 \\
\hline Total & 77 & 88 & 135 & 358 \\
\hline & Grup & mental $\mathrm{AE}$ & mostra 8) & \\
\hline Amostra & Classe & Classe & Classe & Escore \\
\hline & & & & \\
\hline 01 & 12 & 42 & 46 & 134 \\
\hline 02 & 30 & 26 & 44 & 114 \\
\hline 03 & 23 & 31 & 43 & 117 \\
\hline Total & 65 & 99 & 133 & 365 \\
\hline
\end{tabular}




\begin{tabular}{|c|c|c|c|c|}
\hline \multicolumn{5}{|c|}{ Grupo experimental AEHAS (Amostra 10) } \\
\hline \multirow[t]{2}{*}{ Amostra } & \multirow{2}{*}{ Classe } & Classe & \multirow{2}{*}{$\begin{array}{l}\text { iostra 10) } \\
\text { Classe } \\
2\end{array}$} & \multirow[t]{2}{*}{ Escore } \\
\hline & & & & \\
\hline 01 & 44 & 18 & 38 & 94 \\
\hline 02 & 44 & 16 & 40 & 96 \\
\hline 03 & 33 & 16 & 52 & 120 \\
\hline Total & 121 & 50 & 130 & 310 \\
\hline \multicolumn{5}{|c|}{ Grupo experimental AEHAS (Amostra 11) } \\
\hline Amostra & Classe & Classe & Classe & Escore \\
\hline & & & & \\
\hline 01 & 76 & 12 & 12 & 36 \\
\hline 02 & 59 & 07 & 34 & 75 \\
\hline 03 & 64 & 10 & 26 & 62 \\
\hline Total & 199 & 29 & 72 & 173 \\
\hline
\end{tabular}

Com base nos escores encontrados no ensaio cometa foi feita uma relação comparativa entre os tempos de retenção e atividade genotóxica (tabela 12).

Tabela 12 - Comparativo entre padrão e amostra em relação a tempo de retenção e escores de atividade genotóxica do ensaio cometa.

\begin{tabular}{|c|c|c|}
\hline Controle Negat & Escore & \\
\hline Controle Positi & Escore & \\
\hline DMSO & Escore & \\
\hline Padrão n Pico & Tempo de retenção (minutos) & Escore \\
\hline 1 & $28,13-30,54$ & 286 \\
\hline 2 & $30,54-31,66$ & 240 \\
\hline 4 & $32,64-34,13$ & 216 \\
\hline 5 & $34,13-35,22$ & 286 \\
\hline 8 & $38,28-39,28$ & 140 \\
\hline 9 & $39,28-40,84$ & 214 \\
\hline 10 & $40,84-42,57$ & 140 \\
\hline EHAS $n^{\circ}$ Pico & Tempo de retenção (minutos) & Escore \\
\hline 2 & $30,17-32,29$ & 331 \\
\hline 6 & $34,90-35,11$ & 258 \\
\hline 7 & $35,11-37,14$ & 358 \\
\hline 8 & $37,14-38,58$ & 365 \\
\hline 10 & $39,47-41,42$ & 310 \\
\hline 11 & $41,42-42,04$ & 173 \\
\hline
\end{tabular}


Quatro frações (duas do padrão e duas da amostra de extrato) que demonstraram similaridade em relação ao tempo de retenção na cromatografia e atividade genotóxica no ensaio cometa foram selecionadas para análises estruturais em espectrofotometria de massas, para que houvesse uma confirmação de se tratarem da mesma substância e possibilitar um primeiro estudo de separação do composto que estaria causando efeito genotóxico e prejudicando o uso da saponina como adjuvante neste aspecto.

\subsection{Análise e caracterização de substâncias por espectrometria de massa}

Os arquivos provenientes do espectrômetro de massas acoplado ao cromatógrafo, correspondentes a cada uma das quatro frações, foram analisados separadamente por meio do software Xcalibur 2.0 software (Thermo Electron, USA), e para confirmar as massas médias dos fragmentos e a deconvolução das cargas dos espectros foi utilizado o software Mass Analyzer 1.03 (ZHANG \& MARSHALL, 1998). Por não haver um banco de dados com massas glicosídicas de saponinas depositadas previamente, como há para inúmeras proteínas, a comparação de similaridade e identificação de sequências primárias das moléculas das frações não entraram no escopo destas análises.

A espectrometria de massas é baseada na ionização de um composto, que em seguida é separado com base da razão massa/carga $(\mathrm{m} / \mathrm{z})$, e o número de íons que correspondem a cada unidade de $\mathrm{m} / \mathrm{z}$ é registrado na forma de espectros (SILVERSTEIN et al., 2006).

As frações de extrato n06 e n¹0 resultaram em 740,14Da e 740,15Da respectivamente, e as frações do padrão $n^{\circ} 5$ e $n^{\circ} 9$ resultaram e valores de massa de 740,09 Da e 740,17 Da por conseguinte (figuras 22 e 23).

Houve, portanto, uma possível confirmação de se tratarem das mesmas substâncias, as quais não podem ser identificadas de forma exata pela falta de um banco de dados disponível para essa classe de composto. Análises de Ressonância Magnética Nuclear poderão ser feitas futuramente para esta finalidade, com determinação estrutural mais detalhada, além do que recentes técnicas de ressonância têm possibilitado esse estudo sem o emprego de métodos destrutivas (AGRAWAL \& PATHAK, 1996). 
Figura 22- Deconvolução dos espectros das frações do padrão n05 e n09.
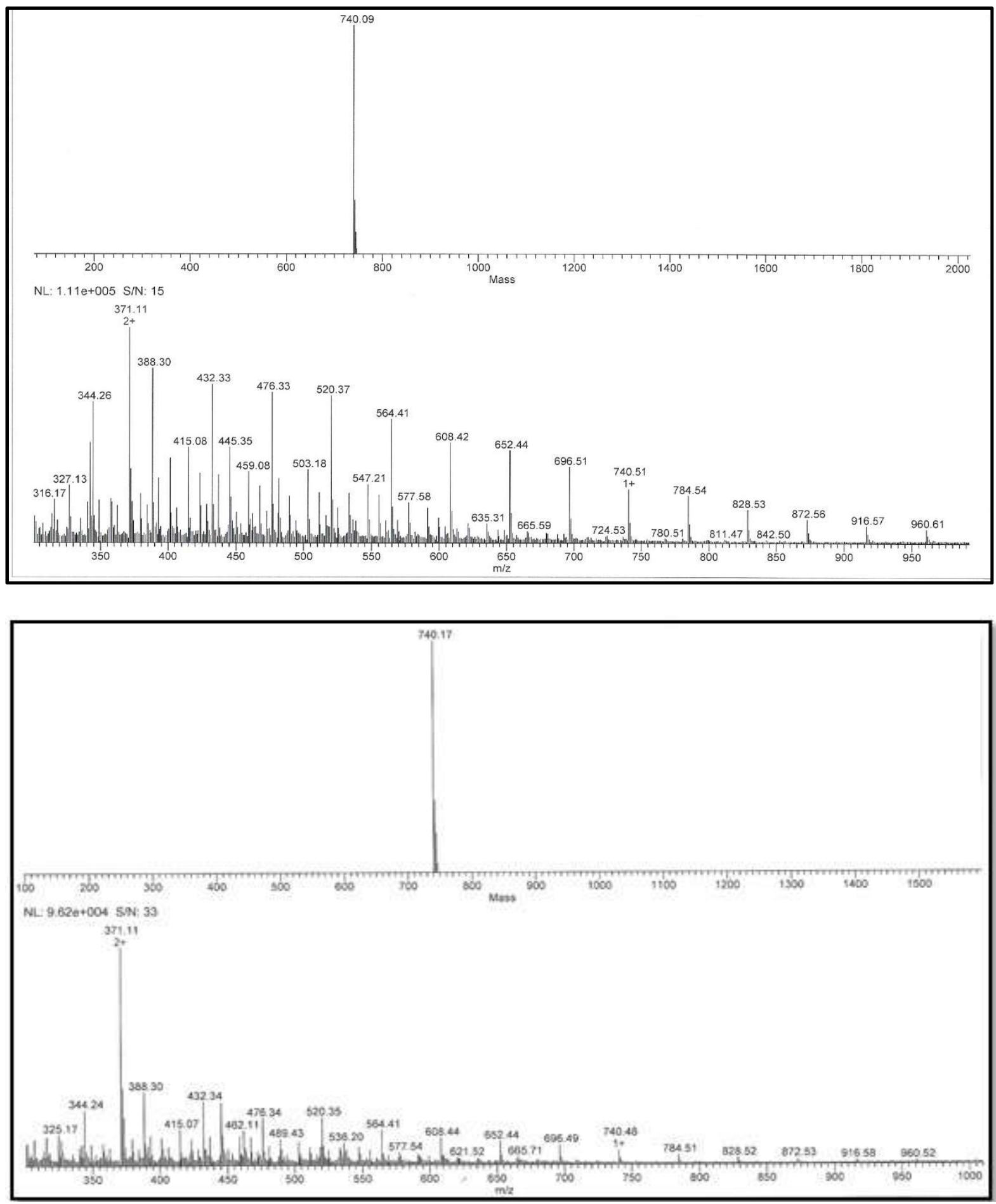

Fonte: Imagens obtidas por meio de análise pelo software Mass Analyzer 1.03.

Através da deconvolução dos íons $(\mathrm{m} / \mathrm{z}$ ) foram encontradas as massas moleculares de 740.09 Da para a fração $n^{\circ} 05$ e 740.17 Da para a fração n09 do padrão. 
Figura 23- Deconvolução dos espectros das frações da amostra n06 e nº 10.
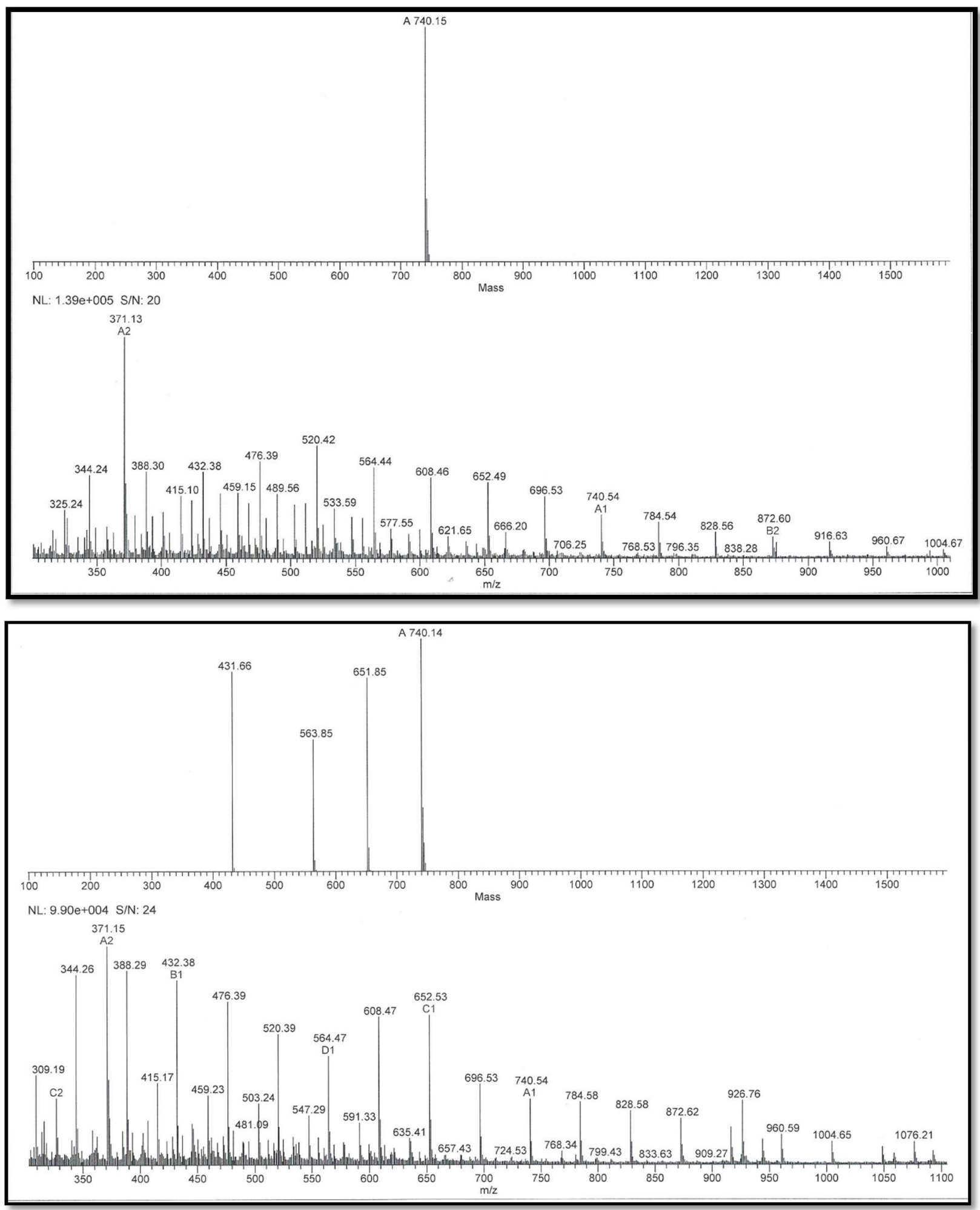

Fonte: Imagens obtidas por meio de análise pelo software Mass Analyzer 1.03.

Através da deconvolução dos íons $(\mathrm{m} / \mathrm{z}$ ) foram encontradas as massas moleculares de 740.15 Da para a fração $n^{\circ} 06$ e 740.14 Da para a fração $n^{\circ} 10$ do padrão. 
6 DISCUSSÃO 
Vacinas são grandes aliados no combate a ações de agentes infecciosos. Sua eficácia tem sido verificada tanto no aspecto profilático como terapêutico. Para aumentar esta eficácia, várias substâncias têm sido administradas conjuntamente ao produto vacinal. Estas substâncias são conhecidas como adjuvantes, do latim adjuvare (melhorar) (SCHIJNS, 2000). Diferentes adjuvantes têm sido utilizados: mineral (hidróxido de alumínio - Alumem), vegetal (saponinas), emulsões (adjuvante incompleto de Freund) e até derivados de agentes infecciosos (adjuvante completo de Freund) (RAMON, 1925; 1926), no entanto, a toxicidade local e / ou sistêmica conferida por esses adjuvantes tem sido um grande desafio para licenciar um novo componente (SUN et al., 2009).

Estas substâncias propiciam maior ação imunológica dos produtos vacinais, o que é de máximo interesse em termos de saúde pública e biotecnológica. Porém, apesar dos adjuvantes estarem sendo utilizados há décadas e haver relatos de reações adversas, ainda não há estudos sobre possíveis ações citotóxicas destes produtos (GUPTA \& SIBER, 1995). O papilomavírus bovino (BPV) é o agente etiológico da papilomatose bovina, doença infectocontagiosa caracterizada pela presença de papilomas que regridem espontaneamente, mas que podem persistir e progredir à malignidade, afetando seguimentos de produção de carne e leite, o que representa um grave problema de pecuária considerando que pelo menos $60 \%$ do gado está contaminado no Brasil (STOCCO DOS SANTOS et al., 1998). Apesar do controle de manejo ser apontado como uma medida de controle da doença há a necessidade do desenvolvimento de novas tecnologias vacinais e de diagnóstico, já que o vírus pode ser transmitido verticalmente (ROPERTO et al., 2012).

No entanto, como todas as vacinas baseadas em proteínas recombinantes, a formulação final requer que se use substâncias capazes de melhorar a resposta imune contra um antígeno específico (REED et al., 2009), além disso, aumentando a resposta imune, os adjuvantes reduzem a quantidade necessária de antígeno na formulação final da vacina, diminuindo seu custo (AGUILAR et al., 2007).

Os compostos minerais (fosfato de cálcio, hidróxido de alumínio) são amplamente utilizados em vacinas humanas e veterinárias. O uso de hidróxido de alumínio, também conhecido como Alumem foi introduzido em 1926 (GLENNY et al., 1926). Entretanto, o Alumem é um indutor pouco eficaz de resposta das células $T$, caracterísica importante no desenvolvimento de uma vacina. Por estes motivos, as 
saponinas emergem como um promissor candidato a adjuvante para uso veterinário (PETROVSKY et al, 2004), devido ao seu maior potencial adjuvante em relação ao alúmem (GUPTA et al., 1995).

Tendo em vista a antigenicidade da proteína $L 1$ e a notável capacidade adjuvante das saponinas, o presente trabalho teve por objetivo avaliar o potencial mutagênico e genotóxico da proteína isolada e purificada, bem como seus efeitos quando associada às saponinas e também compará-la ao hidróxido de alumínio, utilizando testes in vitro.

Os resultados de dignóstico demonstram a ausência de infecção por BPV prévia nas dez amostras. A ausência do vírus nas amostras de sangue é de importante constatação, haja visto que estudos mostraram que células infectadas pelos BPVs 1 , 2 e 4 apresentam altos níveis clastogênicos (ARALDI et al., 2014 a ; ARALDI et al., 2013). Algumas amostras de sangue podem apresentar o vírus, mas sem expressão em epitelio, por estarem em estado de latência (SILVA et al., 2013). No gado assintomático, a ativação do vírus no sangue pode ser independente da infecção produtiva no tecido epitelial (CAMPO et al., 2006).

A presença de BPV no sangue de bezerros recém-nascidos já foi detectada por outros autores (STOCCO DOS SANTOS et al., 1998; FREITAS et al., 2003; YAGUIU et al., 2008), sugerindo a transmissão vertical. Sabe-se que o vírus é capaz de induzir diversas aberrações citogenéticas em sangue periférico (STOCCO DOS SANTOS et al., 1998), sendo o diagnóstico molecular uma ferramenta essencial para garantir que não haverá indução de clastogenicidade pelo vírus e interferência nos demais ensaios.

Os níveis de clastogenicidade foram detectados pelo ensaio cometa e o potencial genotóxico, por meio do teste do micronúcleo. O grau de apoptose foi detectado por citometria de fluxo utilizando Anexina- PI.

Juntos, estes métodos permitem avaliar o potencial mutagênico e citogenéticos das formulações testadas, sendo esta uma necessidade exigida por agências regulamentadoras, já que a toxicidade limita a liberação e o uso de fármacos e estes estudos servem de indicadores para a condução de estudos pré-clínicos, devendo ser realizados em células e posteriormente em animais (MARTIN et al., 2009).

Tais testes foram realizados em células Vero e sangue periférico de bovinos, posto que segundo o International Workshop on Genotoxicity Test Procedures (TICE et al., 2000), pelo menos duas culturas de células independentes devem ser sucessivamente testadas, além do que as células Vero têm contribuído amplamente 
sendo utilizadas, não só para microbiologia, mas também na produção de vacinas de uso humano (OSADA et al., 2014).

A linhagem Vero, originária de rins de macaco Cercopithecus aethiops (African green monkey), é usada rotineiramente por laboratórios de controle de qualidade que monitoram a potência de vacinas (MENDES et al.,1990), esta linhagem não possui propriedades oncogênicas, como foi demonstrado em diversos estudos, sendo aceita pela Organização Mundial de Saúde - OMS - para uso como substrato inclusive na produção de vacinas para humanos (FURESZ et al., 1989; VINCENT FALQUET et al., 1989; HORAUD, 1992).

Os resultados obtidos pelo ensaio cometa, método sensitivo para os estudos de danos ao DNA em células individualizadas (SINGH et al., 1988; SARAN et al., 2008), em sangue periférico, mostraram que o grupo controle negativo apresentou menor número de cometas. Este resultado era esperado, pois o material biológico foi transportado e processado após três horas de sua coleta, reduzindo a interferência de fatores ambientais exógenos, além do mais, as amostras sanguíneas, como verificado no ensaio de PCR, não estavam infectadas por BPV, reduzindo assim a influência de fatores ambientais endógenos que pudessem influenciar os resultados.

O grupo controle positivo apresentou um elevado número de cometas de classe 2, resultado também esperado, pois foi tratado com $50 \mathrm{ug} / \mathrm{mL}$ de ciclofosfamida, quimioterápico e imunossupressor mutagênico, citotóxico e teratogênico (BRITO et al., 2008).

O teste pos-hoc de Dunn não revelou diferenças estatísticas entre alguns grupos testados comparados com o controle positivo, apontando danos citogenéticos compatíveis com este, as amostras tratadas com a proteína $L 1$, as composições vacinais compostas por L1 com saponinas e L1 com Hidróxido de Alumínio, o que sugeriu ser a L1 nesses casos o fator determinante de citogenicidade, já que o DMSO, hidróxido de alumínio, saponinas e controle negativo demonstraram ser significativamente diferentes do controle positivo e não apresentaram diferenças significantes com o controle negativo quando analisados separadamente.

Nos dados obtidos em células Vero os resultados foram próximos aos de sangue periférico para esses tratamentos, porém essas células mostraram-se mais sensíveis ao tratamento somente com saponinas e Hidróxido de Alumínio, os quais Ihes conferiram citogenicidade, sendo somente o diluente DMSO e o controle negativo diferentes significantemente do controle positivo. 
O teste de micronúcleo tem sido amplamente usado como um teste primário em genética toxicológica pela sua capacidade de avaliar genotoxicidade de forma simples e rápida, detectando danos cromossômicos induzidos como um biomarcador de mutagenicidade (HEDLE et al., 1983).

Nos testes com a proteína L1 observou-se um acréscimo de 2,9\% de micronúcleos, na combinação de L1 com saponinas houve um aumento de 18, 9\% de micronúcleos em comparação ao controle negativo, e 9, 9\% ao aplicar a combinação de L1 com hidróxido de alumínio, o que representa quase o dobro de micronúcleos, porém nenhuma amostra ficou próxima ao valor do controle positivo, o qual acrescentou $61,4 \%$ de micronúcleos em relação ao controle negativo que representou apenas $7,7 \%$ de micronúcleos num total de 1000 células contadas. O diluente DMSO acrescentou 3, 6\%, o hidróxido de alumínio $7,1 \%$ e somente a Saponina $14,9 \%$ de micronúcleos.

A soma das porcentagens de micronúcleos encontradas na aplicação das drogas separadas (hidroxído de alumínio ou saponinas) com a porcentagem dos micronúcleos encontrados na aplicação de L1, também separado, aproxima-se da porcentagem encontrada de micronúcleos nas formulações vacinais de L1 com Hidróxido de Alumínio e L1 com Saponinas, esta última estando em desvantagem aumentando levemente o potencial genotóxico da formulação.

O sistema de reparo de DNA é essencial para a manutenção da estabilidade genética e consequentemente para a manutenção da vida, e a importância destes reparos são evidentes, visto o enorme investimento feito pelas células em enzimas para esta finalidade (FRIEDBERG et al., 2005).

Quando ocorre um dano ao DNA, mecanismos de checkpoint são ativados desencadeando uma resposta celular que aciona uma pausa no ciclo celular. Em seguida, dependendo do tipo, do grau da lesão e do estado fisiológico da célula, a resposta celular pode acontecer de duas maneiras: pela ativação do sistema de reparo de DNA, resultando na restauração de sua estrutura química original, ou, se os danos ao DNA forem muito severos, e, portanto, não passíveis de reparação, a célula opta por se auto-eliminar por meio da apoptose (MASLOV \& VIJG, 2009).

Neste contexto o ensaio de anexina V-PI apontou que nenhuma das amostras tratadas apresentaram potencial apoptótico semelhante ao controle positivo, pois estatisticamente houve grande diferença, com exceção do DMSO, o qual apresentou pouca diferença estatística, mas ainda assim significante. 
Entretanto, em relação ao controle negativo (figura 20) as amostras com saponinas, saponinas com L1, DMSO e L1 apresentaram diferenças significantes, estando num estado intermediário de viabilidade celular entre controle positivo e negativo.

Já a combinação vacinal de hidróxido de alumínio com L1 e somente hidróxido de alumínio não apresentaram diferenças significativas com o controle negativo, e, analisando os valores de médias de células viáveis, o hidróxido de alumínio aumentou o número de células viáveis em relação ao controle negativo quando aplicado, não havendo nenhum relato desta capacidade protetora do alumínio na literatura, sendo este um resultado pioneiro.

A capacidade apoptótica das saponinas pode ser atribuída à presença de surfactante, que se liga ao colesterol presente na membrana celular, levando a formação de poros e hemólise (SINGH, 1999). Entre as atividades biológicas, a hemólise é a característica comum a muitas saponinas com estruturas diferentes. Esta atividade deve-se ao fato das saponinas em geral formarem complexos com os esteróides da membrana dos eritrócitos, causando um aumento na permeabilidade e a consequente perda da hemoglobina (COSTA, 2001; WANG et al., 2007).

O efeito hemolitico das saponinas é muito influenciado pela natureza polar dos substituintes ligados à aglicona (VOUTQUENNE et al., 2002), bem como sua atividade imunoadjuvante (SOLTYSIK et al., 1995), contudo as evidências ainda não são conclusivas, além do que a maioria dos estudos centram-se na imunoatividade da saponina Quillaja (KENSIL et al., 1996), que é apenas uma entre tantas existentes e, portanto, difere na estrutura química sendo necessário maiores estudos com outras espécies.

Os resultados também sugerem toxicidade relacionada ao diluente DMSO, 0 qual não apresentou diferença significante com o controle positivo. O DMSO foi escolhido como diluente da saponina, devido as suas propriedades farmacotécnicas e farmacológicas interessantes para uma vacina, pois possui intensa capacidade de penetração, facilitando o carreamento de muitas substâncias a ele associadas através das membranas (BLYTHE et al., 1986; RAND-LUBY et al., 1996) e é miorrelaxante, associado a efeitos tranquilizantes e sedativos (ROSENBAUM, 1965; BRAYTON, 1986;). Essa propriedade sem dúvida decorre principalmente do conforto resultante das outras propriedades, ou seja, antiinflamatória e analgésica (BLYTHE, 1986; BRAYTON, 1986). 
A caracterização química das saponinas, de um modo geral, constitui um árduo trabalho devido ao fato destes compostos apresentarem alto peso molecular. Outro fato complicador é a presença de uma mistura de saponinas no extrato, necessitando a aplicação de técnicas sofisticadas de separação (WANG et al., 2007). A hidrólise foi realizada por via química utilizando um ácido mineral (catalisador), com finalidade de liberar as agliconas, sendo uma etapa útil no esclarecimento parcial de sua estrutura.

Com base nos resultados de cromatografia líquida de alta eficiência, ensaio cometa das frações separadas e espectrometria de massa podemos inferir que as moléculas com alto potencial genotóxico do extrato usado como adjuvante nos experimentos estão presentes também no padrão de saponina, e que embora haja uma pequena diferença em tempo de retenção e massa, o que pode significar apenas uma diferença estrutural no que tange ao tipo de açúcar ligado a sapogenina principal e/ou aos seus tipos de ligações e oxidações (figura 24), havendo portanto, uma confirmação da sua identidade dentro do escopo do trabalho.

A grande complexidade da estrutura química das saponinas consiste na variabilidade das estruturas das agliconas, na natureza das cadeias glicosídicas laterais e na posição em que elas estão ligadas a estrutura da aglicona (FRANCIS et al, 2002), outro fator que também influencia é o estágio de desenvolvimento da planta (HOSTETTMANN; MARSTON, 1995).

Figura 24 - llustração de duas principais sapogeninas que diferem em suas massas molares, sendo a Sarsapogenina (C27H44O3) com 416,64 g/mol e a Diosgenina (C27H42O3) com 414,62 g/mol.

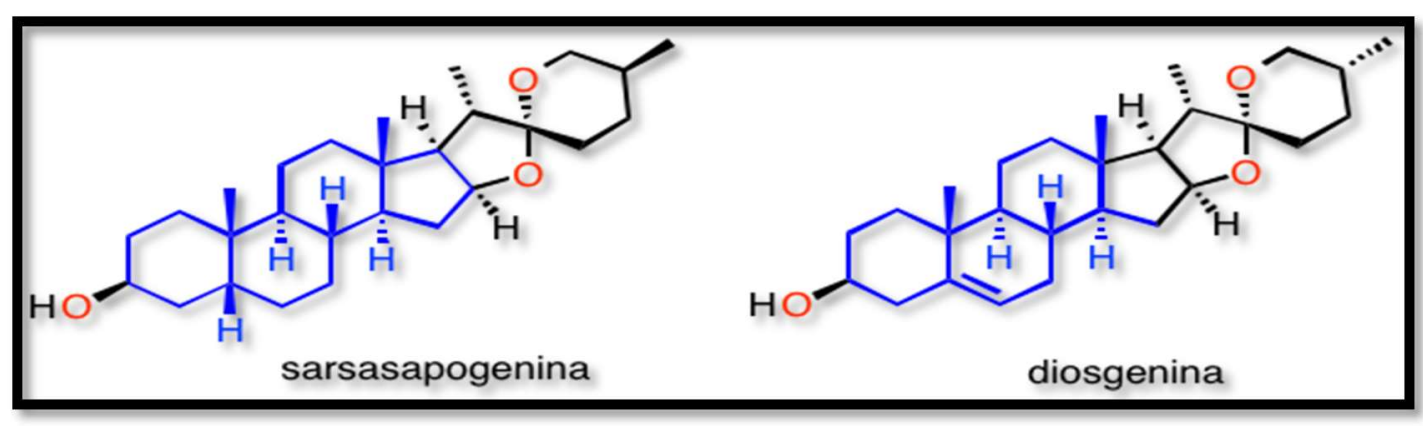

Fonte: https://isqch.wordpress.com/2015/02/04/una-dosis-de-esteroides/ , acesso em 20/01/2019. 
7 CONCLUSÃO 
Observando os resultados, embora os dois produtos vacinais ( L1 + saponina e L1 + hidróxido de alumínio) tenham apresentado danos compatíveis com o controle positivo no ensaio cometa e ambos tenham elevado os níveis de micronúcleo no ensaio de Micronúcleo, no ensaio de Viabilidade Celular os resultados com hidróxido de alumínio foram surpreendentemente positivos, caracterizando- o como um adjuvante seguro, e tornando viável sua associação com a L1, que embora tenha apresentado genotoxidade quando analisada sozinha, teve essa ação deletéria neutralizada quando associada ao hidróxido de alumínio.

Isso pode indicar que os danos encontrados no DNA, por meio do ensaio cometa e de micronúcleo, não levam a apoptose celular por não serem tão severos quanto os provocados pela saponina, podendo ser reparados, já que o aumento da clastogênese é um evento presente na fase precoce da apoptose (NICOLETTI et al, 1991).

A prospecção e manipulação de compostos ativos a partir de produtos naturais possibilita a descoberta de moléculas que podem ser nocivas para uso humano ou animal, ou eficazes frente a diferentes patógenos, e que podem ser exploradas visando diversas aplicações, assim sendo, ao separar as moléculas que causam maior índice de genotoxidade na saponina, podemos vislumbrá-la como um possível adjuvante, caso fossem isoladas estas moléculas genotóxicas, necessitando de um estudo mais detalhado entre estrutura e atividade, e realizando testes em relação a imunogênicidade e toxicidade após manipulação do composto sugerido. 


\section{REFERÊNCIAS BIBLIOGRÁFICAS}

ABDEL-GAWAD, M. M.; EL-SAYED, M. M.; ABDEL-HAMEED, E. S. Molluscicidal steroidal saponins and lipid content of Agave decipiens. Fitoterapia, v. 70, n. 4, p. 371381, 1999.

AGRAWAL, P. K.; PATHAK, A. K. Nuclear magnetic ressonance spectroscopic approaches for the determination of interglycosidic linkage and sequence in oligossaccharides. Phytochmical analysisc, v.7, p. 113-130, 1996

AGUILAR, J. C.; RODRIGUEZ, E. G. Vaccine adjuvants revisited. Vaccine, v. 25, n. 19, p. 3752-3762, 2007.

ALBERTINI, R. J.; ANDERSON, D.; DOUGLAS, G. R.; HAGMAR, L.; HEMMINKI K. K.; MERLO, F. IPCS guidelines for the monitoring of genotoxic effects of carcinogens in humans. Mutat. Res., v.463, n.2, p.111-172, 2000.

ALVES, M.O.; SANTIAGO, E.S.; LIMA, A. R.M. Diagnóstico socioeconômico da região nordestina produtora de sisal. Fortaleza: Banco do Nordeste do Brasil.75 p., 2004.

AMINI, E., et al. Hemolytic and cytotoxic effects of saponin like compounds isolated from Persian Gulf brittle star (Ophiocoma erinaceus). J Coast Life Med, v. 2, n. 10, p. 762-768, 2014.

ANTIGNAC, E., et al. Safety of botanical ingredients in personal care products/cosmetics. Food and Chemical Toxicology, v. 49, n. 2, p. 324-341, 2011.

ARALDI, R. P., et al. Bovine papillomavirus clastogenic effect analyzed in comet assay. BioMed Research International, v. 2013, p. 1-7, 2013.

ARALDI, R. P., et al. Bovine papillomavirus isolation by ultracentrifugation. Journal of Virological Methods, v. 208, p. 119-24, 2014a.

ARALDI, R. Isolamento e identificaçao do papilomavírus bovino em grupo experimental de bovinos para a obtençao de um banco de vírus. [s.I.] Universidade de São Paulo, 2014b.

ARALDI, R. P., et al. Genetics and metabolic deregulation following cancer initiation: A world to explore. Biomedicine \& Pharmacotherapy, v. 82, p. 449-458, 2016.

ARALDI, R. P., et al. Mutagenic Potential ofBos taurus Papillomavirus Type 1 E6 Recombinant Protein: First Description. BioMed research international, v. 2015, 2015.

ARALDI, R. P., et al. Papillomaviruses: a systematic review. Genetics and molecular biology, v. 40, n. 1, p. 1-21, 2017. 
ASSUMPÇÃO, T.I.; PACHEMSHY, J.A.S.; ANDRADE, E.A.; SILVA, N.A.M. Perdas econômicas resultantes de reações vacinais em carcaças da raça Nelore. Revista Brasileira de Saúde e Produção Animal, v.12, p.375-380, 2011.

AUDIBERT, F. Adjuvants for vaccines, a quest. International Immunopharmacology, v. 3, p. 1187-1193, 2003.

BANDEIRA, D. A.; SILVA, O. R. R. F. Aproveitamento de resíduos. O sisal do Brasil. Salvador: Sindifibras, p. 58-61, 2006.

BARTELING, S. J.; VREESWIJK, J. Developments in foot-and-mouth disease vaccines. Vaccine, v. 9, p. 75-88, 1991.

BLYTHE, L.L.; CRAIG, A.M.; CHRISTENSEN, J.M.; APPELL, L.H.; SLIZESKI, M.L. Pharmacokinetic disposition of dimethyl sulfoxide administered intravenously to horses. American Journal of Veterinary Research, v.47, n.08, p.1739-1743, 1986.

BOMFORD, R., et al. Adjuvanticity and ISCOM formation by structurally diverse saponins. Vaccine, v. 10, n. 9, p. 572-577, 1992.

BORZACCHIELLO, G. Bovine papillomavirus infections in animals. Communicating Current Research and Educational Topics and Trends in Applied Microbiology, v. 2, 2007.

BORZACCHIELLO, G.; ROPERTO, F. Bovine papillomaviruses, papillomas and cancer in cattle. Veterinary research, v. 39, n. 5, p. 1, 2008.

BRACKENBURY, T.D.; APPLETON, C.C. A comprehensive evaluation of Agave attenuata, a candidate plant molluscicide in South Africa. Acta Tropical, v.68, p.201213, 1997.

BRAYTON, C.F. Dimethyl sulfoxide (DMSO): a review. Cornell Veterinarian, v.76, n.01, p.76-90, 1986.

BRITO, O.M.; GUIMARÃES, M. F. B.; LANNA, C.C.D. Ciclofosfamida e função ovariana. rev bras reumatol, v. 48, n. 1, p. 39-45, 2008.

BUCK, C. B.; DAY, P. M.; TRUS, B. L. The papillomavirus major capsid protein L1. Virology, v. 445, n. 1, p. 169-174, 2013.

CAMPANA, I.G.; GOIATO, M.C. Tumores de cabeça e pescoço: epidemiologia, fatores de risco, diagnóstico e tratamento. Revista Odontológica de Araçatuba, p. 2031, 2013.

CAMPO, M. Animal models of papilloma virus pathogenesis. Virus Research, v. 89, p. 249-261, 2002.

CAMPO, M. S. Papillomavirus research: from natural history to vaccines and beyond. Horizon Scientific Press, 2006. 
CAMPO, M. S.. Vaccination against papillomavirus in cattle. Clinics in dermatology, v. 15, n. 2, p. 275-283, 1997.

CAMPO M.S., COGGINS L.W. Molecular cloning of bovine papillomavirus genomes and comparison of their sequence homologies by heteroduplex mapping. J Gen Virol, v.63, p.255-64, 1982.

CAMPOS, S. R. C., et al. Chromosome aberrations in cells infected with bovine papillomavirus: comparing cutaneous papilloma, esophagus papilloma, and urinary bladder lesion cells. ISRN oncology, v. 2013, p. 910849, 2013.

CARELLI, M., et al. Medicago truncatula CYP716A12 is a multifunctional oxidase involved in the biosynthesis of hemolytic saponins. The Plant Cell Online, v. 23, n. 8, p. 3070-3081, 2011.

CARVALHO, R. F., et al. Bovine papillomavirus in Brazil: detection of coinfection of unusual types by a PCR-RFLP method. BioMed Research International, v. 2013, n. L, p. $270898,2013$.

CASCIOLA-ROSEN L., ROSEN A., PETRI M., SCHLISSEL M. Surface blebs on apoptotic cells are sites of enhanced procoagulant activity: implications for coagulation events and antigenic spread in systemic lupus erythematosus. Proc Nat Acad Sci USA, v. 93, p.1624-1629, 1996.

CHAMBERS, G., et al. Association of bovine papillomavirus with the equine sarcoid. Journal of General Virology, v. 84, n. 5, p. 1055-1062, 2003.

CHANG, J. C. C.; DIVELEY, J. P.; SAVARY, J. R.; JENSEN, F. C. Adjuvant activity of incomplete Feund's adjuvant. Advanced Drug Delivery Review, v. 32, p. 173-186, 1998.

CHEN, P., LEE, H. FOXM1 induced by E6 oncoprotein promotes tumor invasion and chemoresistance in HPV-infected lung cancer," Cancer Cell \& Microenvironment, v. 2, no. 1, p. 6-9, 2015.

CHEN, S.; LIAO, C.; LAI, Y., et al. "De-oncogenic HPV E6/E7 vaccine gets enhanced antigenicity and promotes tumoricidal synergy with cisplatin," Acta Biochimica et Biophysica Sinica, vol. 46, no. 1, pp. 6-14, 2014.

CHEN, Y., et al. Antioxidant activities of saponins extracted from Radix Trichosanthis: an in vivo and in vitro evaluation. BMC Complement. Altern. Med. 14, 86 (2014).

CHWALEK, M., et al. Structure-activity relationships of some hederagenin diglycosides: haemolysis, cytotoxicity and apoptosis induction. Biochimica et Biophysica Acta (BBA)-General Subjects, v. 1760, n. 9, p. 1418-1427, 2006.

CHWALEK, M.; PLÉ, K.; VOUTQUENNE-NAZABADIOKO, L. Synthesis and hemolytic activity of some hederagenin diglycosides. Chemical and pharmaceutical bulletin, $v$. 52, n. 8, p. 965-971, 2004. 
CLARK, P. W., ARMENTANO, L. E. Effectiveness of neutral detergent fiber in whole cottonseed and dried distillers grains compared with Alfalfa haylage. J. Dairy Sci. v. 76, p. 2644-2650, 1993.

COLLINS, A. R. The comet assay for DNA damage and repair. Molecular biotechnology, v. 26, n. 3, p. 249, 2004.

COSTA, A. F. Fármacos com saponósidios. In: Farmacognosia. v.2. ed. 3. Lisboa: Fundação Calouste Gulbenkian, p.338-357, 2001.

DA COSTA, R. M. Gil; MEDEIROS, R. Bovine papillomavirus: opening new trends for comparative pathology. Archives of virology, v. 159, n. 2, p. 191-198, 2014.

DE VILLIERS E., FAUQUET C., BROKER T.R., BERNARD H.U., ZUR HAUSEN H. Classification of papillomaviruses. Virology, v. 324, p.17-27, 2004.

DIMAIO, D. Viral miniproteins. Annual review of microbiology, v. 68, p. 21-43, 2014.

DOORBAR, J. The papillomaviruses life cycle. J Clin Virol, v. 32, p. 7- 15, 2005.

DAUDT, C., et al. Papilomavirus em rumnantes: uma atualização. Transboundary and Emerging Disease, v.65, p.1381-1395, 2018.

DAUDT, C., et al. Bovine Papilomavirus 24: a novel member of the genus Xipappilomavirus detected in the Amazon Region. Transboundary and Emerging Disease, v.65, p.1381-1395, $2018 b$.

EDELMAN, R. Vaccine Adjuvants. Review of Infection Diseases, v. 2, p. 370-383, 1980.

ESTRADA, A., et al. Isolation and evaluation of immunological adjuvant activities of saponins from Polygala senega L. Comparative immunology, microbiology and infectious diseases, v. 23, n. 1, p. 27-43, 2000.

FABIANI, R., ROSIGNOLI, P., DE BARTOLOMEO, A., FUCCELLI, R., SERVILI, M., MONTEDORO, G., MOROZZI, G. Oxidative DNA damage is prevented by extracts of olive oil, hydroxytyrosol, and other olive phenolic compounds in human blood mononuclear cells and HL60 cells. The Journal of Nutrition, v.138, p. 1411-1416, 2008.

FERNANDES, J.V.; ARAUJO, J.M.G.; FERNANDES T.A.A.M. Biology and natural history of human papillomavirus. Open Acess Journal of Clinical Trial, v. 5, p.1-12, 2013.

FERNANDES, M. P., et al. Mechanism of Trypanosoma cruzi death induced by Cratylia mollis seed lectin. Journal of bioenergetics and biomembranes, v. 42, n. 1, p. 69-78, 2010. 
FLORES, M.; YAMAGUCHI, M.U. Teste de micronúcleo: uma triagem para avaliação genotóxica, Revista Saúde e Pesquisa, v.1, n.3, p. 337-340, 2008.

FLORIN, L.; SAPP, M.; SPODEN, G. A. Host-cell factors involved in papillomavirus entry. Medical microbiology and immunology, v. 201, n. 4, p. 437-448, 2012.

FRANCESCO DE, M.A, et al. Prevaccination distribution of human papillomavirus types in Italian women with high-risk lesions and cervical neoplasia. Intervirology, v.53, p.417-425, 2010.

FRANCIS, G.; KEREM, Z.; MAKKAR, H.P.S.; BECKER, K. The biological action of saponins in animal systems: a review. British Journal of Nutrition, v.88, p. 587-605, 2002.

FRIEDBERG, E. C., et al. DNA Repair and Mutagenesis American Society for Microbiology Press. Washington, DC, 2005.

FURESZ, J., et al. Tumorigenicity testing of various cell substrates for production of biologicals. Developments in biological standardization, v. 70, p. 233-243, 1988.

GARCIA, M. D., et al. Anti-inflammatory activity of Agave intermixta Trel. and Cissussicyoides L., species used in the Caribbean traditional medicine. Journal of Ethnopharmacology, v. 71, n. 3, p. 395-400, 2000.

GAUTHIER, C., et al. Haemolytic activity, cytotoxicity and membrane cell permeabilization of semi-synthetic and natural lupane-and oleanane-type saponins. Bioorganic \& medicinal chemistry, v. 17, n. 5, p. 2002-2008, 2009.

GLENNY, A. T., et al. Immunological notes. xvii-xxiv. The Journal of Pathology, v. 29, n. 1, p. 31-40, 1926.

GONZALEZ S.L., STREMLAU M., HE X., BASILE JR., MUNGER K. J. Virol, v.75, p.7583-7591, 2001.

GONTIJO, A. M. M. C., TICE, R. Teste do cometa para a detecção de dano no DNA e reparo em células individualizadas. Mutagênese Ambiental. Canoas: Ulbra. p. 173200, 2003.

GREEN, M.. Molecular basis for the attack on cancer. Proceedings of the National Academy of Sciences, v. 69, n. 4, p. 1036-1041, 1972.

GRINDATTO, A., et al. Molecular and histological characterization of bovine papillomavirus in North West Italy. Veterinary Microbiology, v.180, n. 1-2, p.113-117, 2015.

GUPTA, R. K.; RELYVELD, E. H.; LINDBLAD, E. B.; BIZZINI, B.; BEN-EFRAIM, S.; GUPTA, C. K. Adjuvants- a balance between toxicity and adjuvanticity. Vaccine, v. 11, p. 293-306, 1993. 
GUPTA, R. K.; SIBER, G. R. Adjuvant for human vaccines- current status, problems and future prospects. Vaccine, v. 13, p. 1263-1276, 1995.

GUTIÉRREZ, A.; RODRIGUEZ, I.M.; JOSE, C. Chemical composition of lipophilic extractives from sisal (Agave sisalana) fibers. Industrial crops and products, v. 28, n. 1, p. 81-87, 2008.

HARTMANN, A. et al. Recommendations for conducting the in vivo alkaline Comet assay. Mutagenesis. v. 18, p. 45-51, 2003.

HE, Z., et al. Mixed nipple infections caused by variant of BPV3 and a putative new subtype of BPV in cattle. Transboundary and emerging diseases, v. 63, n. 1, 2016.

HEDDLE, J. A., SALAMONE, M.F., HITE, M., KIRKHART, B., MAVOURNIN, K., MACGREGOR, J.G. AND NEWELL, G.W. The induction of micronuclei as a measure of genotoxicity. Mutation. Res. v.123, p.61-118, 1983.

HILLEMAN, M. R. Critical appraisal of emulsified oil adjuvants applied to viral vaccine. Progress in Medical Virology, v. 8, p. 131-182, 1966.

HINGORANI,R., et al. Detection of Apoptosis Using the BD Annexin V FITC Assay on the BD FACSVerse ${ }^{\mathrm{TM}}$ System. BD Biosciences, 2011.

HORAUD, F. Absence of viral sequences in the WHO-Vero cell bank a collaborative study. Developments in biological standardization, n. 76, p. 43-46, 1992.

HOSTETTMANN, K.; MARSTON, A. Chemistry and Pharmacology of Natural Products, Saponin. CambridgeUniversityPress, Cftmbridge, 1995.

HU, S., et al. Adjuvant effect of ginseng extracts on the immune responses to immunisation against Staphylococcus aureus in dairy cattle. Veterinary immunology and immunopathology, v. 91, n. 1, p. 29-37, 2003.

JARRETT, W. F. H., O'NEIL, B.W., GAUKROGER, J. M., SMITH, K. T., LAIRD, H.M. \& CAMPO, M.S. Studies on vaccination against papillomaviruses: the immunity after infection and vaccination with bovine papillomaviruses of different types. Veterinary Record, v. 126, p. 473-475, 1990a.

KEHMEIER E., RUHL H., VOLAND B., CONRAD S. M., ANDROPHY E., STOPPLER $\mathrm{H}$. Cellular steady state levels of the "high risk" but not the "low risk" human papillomavirus (HPV) E6 proteins are controlled by proteasome-dependent degradation and independent of their p53 and E6AP binding capabilities. Virology, v.299, p.72-87, 2002.

KENSIL, C. R., WU, J.-Y.; SOLTYSIK, S. Structural and immunological characterization of the vaccine adiuvant QS-21. In: Vaccine Design: The Subunit and Adjuvant Approach (Eds Powell, M.F. and Newman. M.J.). Plenum Publishing Corporation, New York, p. 525-541, 1995. 
KASSIE, F., et al, Review. Single cell gel electrophoresis assay: a new technique for human biomonitoring studies. Mutation Research, v. 463, p. 13-31, 2000.

KENSIL, C.R., et al. Separation and characterization of saponins with adjuvant activity from Quillaja saponaria Molina cortex. The Journal of Immunology, v. 146, n. 2, p. 431437, 1991.

KENSIL, C. R., et al. Structure/function studies on QS-21, a unique immunological adjuvant from Quillaja saponaria. In: Saponins Used in Traditional and Modern Medicine. Springer US, p. 165-172, 1996.

KERR J.F., WYLLIE A.H., CURRIE A.R. Apoptosis: a basic biological phenomenon with wide-ranging implications in tissue kinetics. Br J Cancer. P.26:239-257, 1972.

KHOEI S., DELFAN S., NESHASTEH-RIZ A., MAHDAVI S.R. Evaluation of the combined effect of $2 \mathrm{ME} 2$ and $60 \mathrm{Co}$ on the inducement of DNA damage by IUdR in a spheroid model of the U87MG glioblastoma cancer cell line using alkaline comet assay. Cell J., v. 3(2), p. 83-90, 2011.

KINTIA, P. K. Chemistry and biological activity of steroid saponins from Moldovian plants. In: Saponins Used in Traditional and Modern Medicine. Springer US, 1996. p. 309-334.

KUMAR, R.; DWIVEDI, N.; SINGH, R. K.; KUMAR, S. RAI, V. P.; SINGH, M. A review on molecular characterization of pepper for capsaicin and oleoresin. Internation Jounal of Plant Breeding and Genetics, v.5, 99-110, 2011.

LUNARDI, M.; ALCANTARA, B.; OTONEL, R., et al. Bovine papillomavirus type 13 DNA in equine sarcoids. Journal of Clinical microbiology, v.51, n. 7, p. 2167-2171, 2013.

MARTIN, A. R., et al. Caracterização química e estrutural de fibra de sisal da variedade Agave sisalana. Polímeros: Ciência e Tecnologia, v. 19, n. 1, 2009.

MASLOV, A. Y.; VIJG, J. Genome instability, cancer and aging. Biochimica et Biophysica Acta (BBA)-General Subjects, v. 1790, n. 10, p. 963-969, 2009.

MAZZUCHELLI-DE-SOUZA, J., et al. Expression and in Silico analysis of the recombinant bovine papillomavirus E6 protein as a model for viral oncoproteins studies. BioMed research international, v. 2013, 2013.

McBRIDE, A.A., et al. Hitchhiking on host chromatin: how papillomaviruses persist. Biochim Biophys Acta, v.1819(7), p.5, 2012.

MELO, T. C., et al. Cytogenetic studies in peripheral blood of bovines afflicted by papillomatosis. Veterinary and comparative oncology, v. 9, n. 4, p. 269-74, 2011.

MELO, T. C., et al. Phylogenetic classification and clinical aspects of a new putative Deltapapillomavirus associated with skin lesions in cattle. Genetics and Molecular Research, v. 13, n. 2, p. 2458-2469, 2014. 
MENDES,I.F.; et al. Statistical comparison of the micro and macro techniques in the assessment of the measles vaccines potency testing. In: 5 o Encontro Nacional de Virologia. Resumos, p. 253. São Lourenço, MG, 1990.

MITCHELMORE C.L., CHIPMAN J.K. DNA strand breakage in aquatic organisms and the potential values of the comet assay in environmental monitoring. Mutat Res., v.399, p.135-147, 1998.

MODOLO, G.D. Bovine papillomavirus L1 protein (bpv-1): production in bacteria and tobacco plants. 1994. Tese (doutorado). Universidade Estadual de Campinas, São Paulo.

MÓDOLO, D.G., ARALDI R.P., MAZZUCHELLI-DE-SOUZA J., PEREIRA A., PIMENTA D.C, et al. Integrated analysis of recombinant BPV-1 L1 protein for the production of a bovine papillomavirus VLP vaccine. Vaccine, v.35, p. 1590-1593, 2017.

MOREIN, B., ERIKSSON, M. V., SJOLANDER, A.; BENGTSSON, K. L. Novel adjuvants and vaccine delivery systems. Veterinary Immunology and Immunopathology, v. 54, p. 373-384, 1996.

MORO, E.; JUNQUEIRA, J.O.B.; UMEHARA, O. Levantamento da incidência de reações vacinais e/ou medicamentosas em carcaças de bovinos na desossa em frigoríficos no Brasil. A Hora Veterinária, v.123, p.55-57, 2001.

MORRIS, J. D., CROOK, T., BANDARA, L. R., DAVIES, R., LATHANGUE, N. B., VOUSDEN, K. H. Human papillomavirus type 16 E7 regulates E2F and contributes to mitogenic signalling. Oncogene, v.8, p. 893-898, 1993.

MUNDAY, J. Bovine and Human Papillomaviruses: A Comparative Review. Veterinary Pathology, n. June, 2014.

MUNDAY, J. S., et al. Multiple oral carcinomas associated with a novel papillomavirus in a dog. Journal of Veterinary Diagnostic Investigation, v. 27, n. 2, p. 221-225, 2015.

NASCIMENTO, G. A., et al. Electrochemical DNA biosensor for bovine papillomavirus detection using polymeric film on screen-printed electrode. Biosensors \& bioelectronics, v. 38, n. 1, p. 61-6, 2012.

NASCIMENTO, G. A., et al. Electrochemical DNA biosensor for bovine papillomavirus detection using polymeric film on screen-printed electrode. Biosensors \& bioelectronics, v. 38, n. 1, p. 61-6, 2012.

NASIR, L.; REID, S. W. J. Bovine papillomaviral gene expression in equine sarcoid tumours. Virus research, v. 61, n. 2, p. 171-175, 1999.

NAVES, I.M. Sisal - safra 2012/2013 : comercialização - proposta de ações. Disponível em: https://www.conab.gov.br/OlalaCMS/uploads/arquivos/12 1029114531 sisal2012. Acesso em 03 jun. 2017. 
NICHOLLS, P. K.; STANLEY, M. A. The immunology of animal papillomaviruses. Veterinary immunology and immunopathology, v. 73, n. 2, p. 101-127, 2000.

NERI M., MILAZZO D., UGOLINI D., MILIC M., CAMPOLONGO A., PASQUALETTI P., BONASSI S.Mutagenesis, v. 30(1), p.155-63, 2015.

NICOLETTI, I., et al. A rapid and simple method for measuring thymocyte apoptosis by propidium iodide staining and flow cytometry. Journal of immunological methods, $v$. 139, n. 2, p. 271-279, 1991.

NORONHA V., MELLO W., VILLA L.L., MACEDO R., BISI F., MOTA R., SASSAMOTO K., MONTEIRO T., LINHARES, A. Human papillomavirus associated with uterine cervix lesions. Rev Soc Bras Med Trop, v. 32, p. 235-240, 1999.

O'HAGAN, D. T.; MacKICHAN, M. L.; SINGH, M. Recent developments in adjuvants for vaccines against infectious diseases. Biomolecular Engineering, v. 18, p. 69-85, 2001.

OLIVE P.L., BANATH J.P. The comet assay: a method to measure DNA damage in individual cells. Nat Protoc, v.1, p.23-29, 2006.

OLSON, C., SEGRE, D., SKIDMORE, L.V., Further observations on immunity to papillomavirus. Am. J. Vet. Res. v.21, p. 233-242, 1960.

ORTEGA, C., et al. IL-17-producing CD8+ T lymphocytes from psoriasis skin plaques are cytotoxic effector cells that secrete Th17-related cytokines. Journal of leukocyte biology, v. 86, n. 2, p. 435-443, 2009.

ORTH G., FAVRE M. Human papillomaviruses. Biochemical and biologic properties. Clin Dermatol, v.3, p.27-42, 1985.

OSADA, N., et al. The genome landscape of the African green monkey kidney-derived Vero cell line. DNA research, v. 21, n. 6, p. 673-683, 2014.

PAHEL, G., et al. Structural and functional characterization of the HPV16 E7 protein expressed in bacteria. Journal of Biological Chemistry, v. 268, n. 34, p. 26018-26025, 1993.

PARANHOS DA COSTA, M. J. R.; TOLEDO, L. M.; SCHMIDEK, A. Boas práticas de manejo: vacinação. Editora Funep: Jaboticabal, 2006.

PATIL, P. K.; BAYRY, J.; RAMAKRISHNA, C.; HUGAR, B.; MISRA, L. D.; NATARAJAN, C. Immune response of goats against foot-and-mouth disease quadrivalent vaccine: comparison of double oil emulsion and aluminium hydroxide gel vaccines in eliciting immunity. Vaccine, v. 20, p. 88, 2002.

PENG, S., et al. Sequential cisplatin therapy and vaccination with HPV16 E6E7L2 fusion protein in saponin adjuvant GPI-0100 for the treatment of a model HPV16+ cancer. PloS one, v. 10, n. 1, p. e116389, 2015. 
PETROVSKY, N.; AGUILAR, J.C. Vaccine adjuvants: current state and future trends. Immunology and cell biology, v. 82, n. 5, p. 488, 2004.

RAMIREZ, A.; SALDANHA, P.H. Micronucleus Investigation of Alcoholic Patients with Oral Carcinomas. Genet. Mol. Res. Mol. Res., v. 1, no. 3, p. 246-260, 2002.

RAMON, G. Sur l'augmentation anormale de l'antitoxine chez les chevaux producteurs de serum antidiphterique. Bulletin de la Societé Central de Medecine Veterinaire, v. 101 , p. 227-234, 1925

RAND-LUBY, L.; POMMIER, R.F.; WILLIAMS, S.T.; WOLTERING, E.A.; SMALL, K. A.; FLETCHER, W.S. Improved outcome of surgical flaps treated with topical dimethylsulfoxide. Annals of Surgery, v.224, n.4, p.583-590, 1996.

REED, S. G., et al. New horizons in adjuvants for vaccine development. Trends in immunology, v. 30, n. 1, p. 23-32, 2009.

RIBEIRO FILHO, J. Cultura do sisal. Universidade Rural do Estado de Minas Gerais. Viçosa - MG, 1967

RIBEIRO-MULLER, L.; MULLER, M. Prophylactic papillomavirus vaccines. Clinics in dermatology, v. 32, n. 2, p. 235-247, 2014.

RIEGER, R.M.A.; GREEN, M. M. A Glossary of Genetics and Cytogene- Glossary of Genetics and Cytogenetics.London: Allen and Unwin, p.507, 1968.

RIVERA, E., HU, S., CONCHA, C. Ginseng and aluminium hedroxide act senergisticalle as vaccine adjuvants. Vaccine, v.21, p. 1149-57, 2003.

RODEN R.B., et al. Sequential cisplatin therapy and vaccination with HPV16 E6E7L2 fusion protein in saponin adjuvant GPI-0100 for the treatment of a model HPV16+ cancer. Vaccine, v. 5, p.10, 2015

ROPERTO, S., et al. Productive infection of bovine papillomavirus type 2 in the placenta of pregnant cows affected with urinary bladder tumors. PLoS One, v. 7, n. 3, p. e33569, 2012.

ROSENBAUM, E.E.; HERSCHLER, R.J.; JACOB, S.W. Dimethyl sulfoxide in musculoskeletal disordens. Journal of the American Medical Association, v.192, n.02, p.309-313, 1965.

SANTOS, D'A. J. Produção e consumo. In: ANDRADE, W. (Org.). O Sisal no Brasil. Salvador: SINDIFIBRAS; Brasília, D. F.: cap.4, p.45-55, Apex, 2006.

STOCCO DOS SANTOS, R. C., et al. Bovine papillomavirus transmission and chromosomal aberrations: an experimental model. The Journal of general virology, $\mathrm{v}$. 79 (Pt 9), p. 2127-35, 1998. 
SARAN, R.; TIWARI, R.K.; REDDY, P.P.; AHUJA, YR. Risk assessment of oral cancer in patients with pre-cancerous states of the oral cavity using micronucleus test and challenge assay. Oral Oncol, v. 44, p. 354-360, 2008.

SARKER, S.D; NAHAR, L.; Química para estudantes de Farmácia: Química Geral, Orgânica e de Produtos Naturais. Rio de Janeiro: Guanabara Koogan, 2009.

SCHILLER, J. T., VASS, W. C. \& LOWY, D. L. Identification of a second transforming region in bovine papillomavirus DNA. Proc. natn. Acad. Sci. U.S.A. v.81, 7880-7884, 1984.

SCHINJS, V.E.J.C. Immunological Concepts of Vaccine Adjuvant Activity. Current Opinion in Immunology, v. 12, p. 456-463, 2000

SCHUCHAT, A.; JACKSON, L. A. Princípios de imunização e uso de vacinas. Doenças Infecciosas de Harrison, p. 28, 2015.

SHARMA, V., et al. Phytochemical analysis and evaluation of antioxidant activities of hydro-ethanolic extracts of Moringa oleifera Lam. pods. J. Pharm. Res, v. 4, p. 554557, 2011.

SHOPE, R.E. Immunization of rabbits to infectious papillomatosis. J Exp Med, v. 65, p.607-624, 1937.

SILVA, F., et al. Novel Bovine pappilomavirus type discovered by rolling-circle amplification coupled with next-generation sequencing. Plos One, v.11, n.9, p.1-11, 2016.

SILVA, M., et al. Utilização de fitoterápicos nas unidades básicas de atenção à saúde da família no município de Maracanaú (CE). Revista Bras.Farmacognosia, v.16, p. 455-462, 2006.

SILVA, M. A R., et al. Detection and expression of bovine papillomavirus in blood of healthy and papillomatosis-affected cattle. Genetics and molecular research : GMR, v. 12, n. 3, p. 3150-6, 2013.

SILVA, M.D., et al. Determinação de glifosato e ácido aminometilfosfônico em águas superficiais do Arroio Passo do Pilão. Pesticidas: Res.Econotoxicologia Meio Ambiente, n.13, p.19-28, 2003.

SILVERSTEIN, R.M.; WEBSTER, F.X.; KIEMLE, D.J.; Identificação Espectrométrica de Compostos Orgânicos, $7^{a}$ ed, LTC Editora, Rio de Janeiro, 2006.

SIMÕES, C. M. O.; SCHENKEL, E. P.; GOSMANN, G.; et al. Farmacognosia: da Planta ao medicamento. 9ed. Porto Alegre/Florianópolis Ed.Universiade/UFRGS/Ed. Da UFSC, 1999.

SINGH N.P., MCCOY M.T., TICE R.R., SCHNEIDER E.L. A simple technique for quantitation of low levels of DNA damage in individual cells. Exp Cell Res, v. 175, p.184-191, 1988. 
SINGH, M.; O'HAGAN, D. T. Recent advances in veterinary vaccine adjuvants. International Journal of Parasitology, v. 33, p. 469-478, 2003.

SLOVIN S.F., RAGUPATHI G., FERNANDEZ C., JEFFERSON M.P., DIANI M., et al. A bivalent conjugate vaccine in the treatment of biochemically relapsed prostate cancer: a study of glycosylated MUC-2-KLH and Globo H-KLH conjugate vaccines given with the new semi-synthetic saponin immunological adjuvant GPI-0100 OR QS21. Vaccine, v. 23, p. 3114-3122, 2005.

SOLTANI, M., et al. Hemolytic and cytotoxic properties of saponin purified from Holothuria leucospilota sea cucumber. Reports of biochemistry \& molecular biology, v.3, n. 1, p. 43, 2014.

SOLTYSIK, S., et al. Structure/function studies of QS-21 adjuvant: assessment of triterpene aldehyde and glucuronic acid roles in adjuvant function. Vaccine, v. 13, n. 15, p. 1403-1410, 1995.

SUN, H.X., XIE, Y., YE, Y.P. Advances in saponin-based adjuvants. Vaccine 27:17871796, 2009b.

SYRJANEN S.M., SYRJANEN K.J. New concepts on the role of human papillomaviruses in cell cycle regulation. Ann Med, v.31, p.175-87, 1999.

TERRADAS, M.M., et al. DNA lesions sequestered in micronuclei induce a local defective-damage response, DNA Repair. Amsterdam. v.8, p.1225-1234, 2010.

TICE, R. R., et al. Single cell gel/comet assay: guidelines for in vitro and in vivo genetic toxicology testing. Environmental and molecular mutagenesis, v. 35, n. 3, p. 206-221, 2000.

THOMAS P., UMEGAKI K., FENECH M. Nucleoplasmic bridges are a sensitive measure of chromosome rearrangement in the cytokinesis-block micronucleus assay. Mutagen. v. 18(2), p.187-94, 2003.

VALENTE, D.,et al. Use of genotoxicity biomarkers and gene expression on the evaluation of gas station attendants exposed to gasoline fumes. Rev. bras. saúde ocup. [online], vol.42, suppl.1, e2s, 2017.

VAN DYK, E., et al. Detection and characterisation of papillomavirus in skin lesions of giraffe and sable antelope in South Africa. Journal of South Africa Veterninary Assiciation, v. 82, n. 2, p. 80-85, 2011.

VAN ENGELAND M., RAMAEKERS F.C., SCHUTTE B., REUTELINGSPERGER C.P. A novel assay to measure loss of plasma membrane asymmetry during apoptosis of adherent cells in culture. Cytometry. p.24:131-139, 1996.

VERMES I., HAANEN C., STEFFENS-NAKKEN H., REUTELINGSPERGER C.P. A novel assay for apoptosis. Flow cytometric detection of phosphatidylserine expression 
on early apoptotic cells using fluorescein labelled Annexin V. J Immunol Methods. p.184:39-51, 1995.

VIGO, C. L. S., NARITA, E., MARQUES, L. C. Influências da variação sazonal e tipos de secagem nas características da droga vegetal - raízes de Pfaffia glomerata (Spreng.) Pedersen (Amaranthaceae). Rev. Bras. Farmacogn. v.14, p.137-144, 2004.

VINCENT-FALQUET, J. C., et al. Qualification of working cell banks for the Vero cell line to produce licensed human vaccines. Developments in biological standardization, v. 70, p. 153-156, 1988.

VOUSDEN, K. Interactions of human papillomavirus transforming proteins with the products of tumor suppressor genes. The FASEB journal, v.7, n.10, p.872-879, 1993.

VOUTQUENNE, L., et al. Structure-activity relationships of haemolytic saponins. Pharmaceutical biology, v.40, n.4, p.253-262, 2002.

WANG, J. W.; RODEN, R. B.S. L2, the minor capsid protein of papillomavirus. Virology, v. 445, n. 1, p. 175-186, 2013.

WANG, Y., et al. Exploration of the correlation between the structure, hemolytic activity, and cytotoxicity of steroid saponins. Bioorganic \& Medicinal Chemistry.v.15.p .25282532, 2007.

WHITE, E.; HOWLEY, P. Proteomic approaches to the study of papillomavirus - host interactions. Virology, v.435, p.57-69, 2013.

WILLIAMS, J. R., GONG, H., Biological activities and syntheses of steroidal saponins: the shark-repelling pavoninins. Lipids. v. 42, p. 77-86, 2007.

WU, M., Rode, A. The micronucleus assay in human lymphocytes after high radiation doses (5-15Gy). Mutat Res., v. 502(1-2), p.47-51, 2002.

XIE, G., et al. Triterpene saponins from the leaves of Ilex pernyi. Helvetica Chimica Acta, v. 91, n.9, p. 1630-1639, 2008.

ZHANG, Z, MARSHALL, A.G., A universal algorithm for fast and automated charge state deconvolution of electrospray mass-to-charge ratio spectra. Journal of the American Society for Mass Spectrometry, v. 9, n.3, p. 225-233, 1998.

ZHENG, Z.; BAKER, C. C. Papillomavirus genome structure, expression, and posttranscriptional regulation. Frontiers in bioscience: a journal and virtual library, v. 11, p. 2286, 2006.

ZHOU, F.; SUN, H.; WANG, Y. Porcine bocavirus: achievements in the past five years. Viruses, v. 6, n. 12, p. 4946-4960, 2014. 